\title{
Pacific Northwest Laboratory Annual Report for 1986 to the DOE Office of Energy Research
}

Part 3 Atmospheric Sciences

June 1987

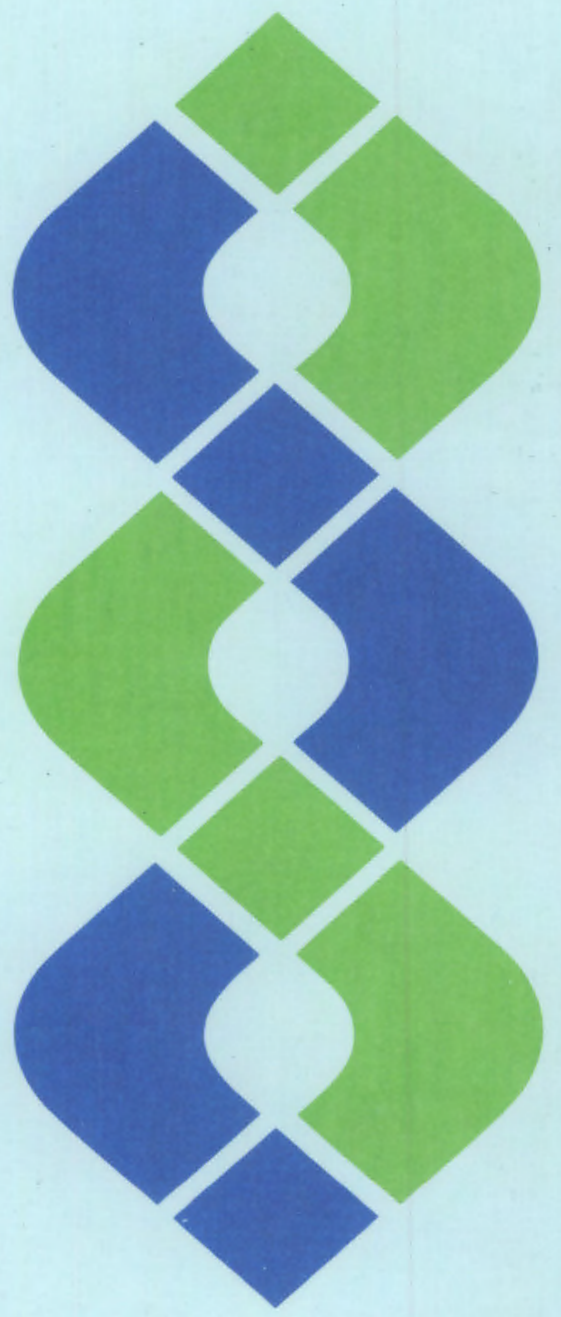

Prepared for the U.S. Department of Energy under Contract DE-AC06-76RLO 1830

Pacific Northwest Laboratory Operated for the U.S. Department of Energy by Battelle Memorial Institute 


\title{
DISCLAIMER
}

This report was prepared as an account of work sponsored by an agency of the United States Government. Neither the United States Government nor any agency thereof, nor Battelle Memorial Institute, nor any of their employees, makes any warranty, expressed or implied, or assumes any legal liability or responsibility for the accuracy, completeness, or usefulness of any information, apparatus, product, or process disclosed, or represents that its use would not infringe privately owned rights. Reference herein to any specific commercial product, process, or service by trade name, trademark, manufacturer, or otherwise, does not necessarily constitute or imply its endorsement, recommendation, or favoring by the United States Government of any agency thereof, or Battelle Memorial Institute. The views and opinions of authors expressed herein do not necessarly state or reflect those of the United States Government or any agency thereof, or Battelle Memorial Institute.

\author{
PACIFIC NORTHWEST LABORATORY \\ operated by \\ BATTELLE MEMORIAL INSTITUTE \\ for the \\ UNITED STATES DEPARTMENT OF ENERGY \\ under Contract DE-AC06-76RLO 1830
}

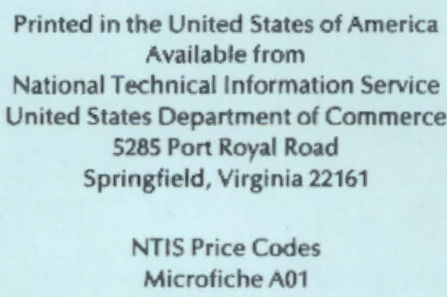




\section{Pacific Northwest Laboratory} Annual Report for 1986 to the DOE Office of Energy Research

\section{Part 3 Atmospheric Sciences}
C. E. Elderkin and Staff Members of Pacific Northwest Laboratory

June 1987

Prepared for the U.S. Department of Energy under Contract DE-ACO6-76RLO 1830

Pacific Northwest Laboratory

Richland, Washington 99352 


\section{PREFACE}

This 1986 annual report from Pacific Northwest Laboratory (PNL) to the Department of Energy (DOE) describes research in environment, health, and safety conducted during fiscal year 1986. The report again consists of five parts, each in a separate volume.

The five parts of the report are oriented to particular segments of our program. Parts 1 to 4 report on research performed for the DOE Office of Health and Environmental Research in the Office of Energy Research. Part 5 reports progress on all research performed for the Assistant Secretary for Environment, Safety and Health. In some instances, the volumes report on research funded by other DOE components or by other governmental entities under interagency agreements. Each part consists of project reports authored by scientists from several PNL. research departments, reflecting the multidisciplinary nature of the research effort.

The parts of the 1986 Annual Report are:

Part 1: Biomedical Sciences

Program Manager - J. F. Park D. L. Felton, Report Coordinator and Editor

Part 2: Environmental Sciences

Program Manager - R. E. Wildung

R. E. Wildung, Report Coordinator

K. A. Borgeson and

S. G. Weiss, Editors

Part 3: Atmospheric Sciences

Program Manager - C. E. Elderkin C. E. Elderkin, Report Coordinator

E. L. Owczarski, Editor

Part 4: Physical Sciences

Program Manager - L. H. Toburen $\quad$ L. H. Toburen, Report Coordinator

P. L. Gurwell, Editor

Part 5: Nuclear and Operational Safety

Program Managers - L. G. Faust

L. G. Faust, Report Coordinator

W. E. Kennedy, Jr.

S. K. Ennor, Editor

J.M. Selby

B. L. Steelman

Activities of the scientists whose work is described in this annual report are broader in scope than the articles indicate. PNL staff have responded to numerous requests from DOE during the year for planning, for service on various task groups, and for special assistance.

A major effort was in response to OHER's request for assistance in collecting information on the release of radioactivity from the nuclear power plant accident at Chernobyl. Environmental and chemical scientists participated in collecting and analyzing atmospheric and environmental samples in Sweden, over the Pacific Ocean, along the northwest coast of North America and along the path of the radioactive plume as it passed across the United States.

Credit for this annual report goes to the many scientists who performed the research and wrote the individual project reports, to the program managers who directed the research and coordinated the technical progress reports, to the editors who edited the individual project reports and assembled the five parts, and to Ray Baalman, editor in chief, who directed the total effort. 
Members of the Scientific Advisory Committee established last year are:

\author{
Dr. Franklin I. Badgley \\ Dr. Leo K. Bustad \\ Dr. Franklin Hutchinson \\ Dr. Albert W. Johnson \\ Dr. J. Newell Stannard
}

\author{
University of Washington \\ Washington State University \\ Yale University \\ San Diego State University \\ University of Rochester \\ University of California, San Diego
}

W. J. Bair, Manager

S. Marks, Associate Manager

Environment, Health and Safety

Research Program

Previous reports in this series:

\section{Annual Report for}

\begin{tabular}{|c|c|}
\hline 1951 & HW-25021, HW-25709 \\
\hline 1952 & HW-27814, HW-28636 \\
\hline 1953 & HW-30437, HW-30464 \\
\hline 1954 & HW-30306, HW-33128, HW-35905, HW-35917 \\
\hline 1955 & HW-39558, HW-41315, HW-41500 \\
\hline 1956 & $H W-47500$ \\
\hline 1957 & HW-53500 \\
\hline 1958 & HW-59500 \\
\hline 1959 & HW-63824, HW-65500 \\
\hline 1960 & HW-69500, HW-70050 \\
\hline 1961 & HW-72500, HW-73337 \\
\hline 1962 & HW-76000, HW-77609 \\
\hline 1963 & HW-80500, HW-81746 \\
\hline 1964 & BNWL-122 \\
\hline 1965 & BNWL-280; BNWL-235, Vol. 1-4; BNWL-361 \\
\hline 1966 & BNWL-480, Vol. 1; BNWL-481, Vol. 2, Pt. 1-4 \\
\hline 1967 & BNWL-714, Vol. 1; BNWL-715, Vol. 2, Pt. 1-4 \\
\hline 1968 & BNWL-1050, Vol. 1, Pt. 1-2; BNWL-1051, Vol. 2, Pt. 1-3 \\
\hline 1969 & BNWL-1306, Vol. 1, Pt. 1-2; BNWL-1307, Vol. 2, Pt. 1-3 \\
\hline 1970 & BNWL-1550, Vol. 1, Pt. 1-2; BNWL-1551, Vol. 2, Pt. 1-2 \\
\hline 1971 & BNWL-1650, Vol. 1, Pt. 1-2; BNWL-1651, Vol. 2, Pt. 1-2 \\
\hline 1972 & BNWL-1750, Vol. 1, Pt. 1-2; BNWL-1751, Vol. 2, Pt. 1-2 \\
\hline 1973 & BNWL-1850, Pt. 1-4 \\
\hline 1974 & BNWL-1950, Pt. 1-4 \\
\hline 1975 & BNWL-2000, Pt. 1-4 \\
\hline 1976 & BNWL-2100, Pt. 1-5 \\
\hline 1977 & PNL-2500, Pt. 1-5 \\
\hline 1978 & PNL-2850, Pt. 1-5 \\
\hline 1979 & PNL-3300, Pt. 1-5 \\
\hline 1980 & PNL-3700, Pt. 1-5 \\
\hline 1981 & PNL-4100, Pt. 1-5 \\
\hline 1982 & PNL-4600, Pt. 1-5 \\
\hline 1983 & PNL-5000, Pt. 1-5 \\
\hline 1984 & PNL-5500, Pt. 1-5 \\
\hline 1985 & PNL-5750, Pt. 1-5 \\
\hline
\end{tabular}




\section{FOREWORD}

The goals of atmospheric research at Pacific Northwest Laboratory (PNL) are to describe and predict the nature and fate of atmospheric contaminants and to develop an understanding of the atmospheric processes contributing to their distribution on local, regional, and continental scales. In 1986, atmospheric research examined the transport and diffusion of atmospheric contaminants in areas of complex terrain and participated in a large, multilaboratory program to assess the precipitation scavenging processes important to the transformation and wet deposition of chemicals composing "acid rain." In addition, during 1986, a special opportunity for measuring the transport and removal of radioactivity occurred after the Chernobyl reactor accident in April 1986.

The description of atmospheric research at PNL is organized in terms of the following study areas:

- Atmospheric Studies in Complex Terrain

- Large-Scale Atmospheric Transport and Processing of Emissions.

\section{Atmospheric Studies in Complex Terrain}

Air pollution in mountainous regions is a particularly difficult problem because of the complexity of meteorological conditions over spatial scales ranging from individual valleys to systems of many valleys and ridges of a region, and the diurnal coupling/decoupling phenomena between air in individual valleys and the regional convective boundary layer. This study area has coordinated research activities in the areas of boundary layer meteorology, development of valley circulations and their interactions with synoptic flow, and the transport and dispersion of contaminated air parcels in mountainous terrain settings. This coordination attempts to integrate theoretical analysis, model development, and results from field experiments. The improved understanding of transport and diffusion in complex terrain gained through this interactive approach will allow the development of assessment models that can be applied with improved reliability in the siting of energy-producing facilities in the western United States.

\section{Large-Scale Atmospheric Transport and Processing of Emissions}

Understanding the large-scale transport of contaminants in the atmosphere and their movement and chemical behavior within cloud systems is important in developing methods to predict the deposition of such contaminants. A current major effort is our participation in the Processing of Emissions by Clouds and Precipitation (PRECP) program.

PRECP is a multilaboratory effort to improve understanding of the phenomena that are important in "acid rain." Ultimately, understanding of these processes will contribute to the implementation of effective control strategies. Personnel at PNL are primarily responsible for advances in understanding of precipitation scavenging; activities in 1986 were principally in the conduct of two large-scale field studies. Data obtained from these and earlier experiments are now being analyzed and will be used to increase the realism of regional-scale "acid rain" numerical models being developed elsewhere as part of the National Acid Precipitation Assessment Program. 
A dramatic event, the Chernobyl reactor accident in April 1986, provided a unique opportunity to obtain data on the atmospheric processing of radioactive material. A team of scientists from PNL and other organizations gathered aircraft samples of air, precipitation, and cloud water, and surface data on air, rain, surface water, and vegetation, as the plume crossed the western United States. The data gathered will be used to test models of atmospheric transport and diffusion (defining horizontal diffusion at distances much farther than previously possible) and of wet and dry deposition.

This report describes the progress in FY 1986 in each of these areas. A divider page summarizes the goals of each area and lists, as bulleted items, project titles that support research in each area. 


\section{CONTENTS}

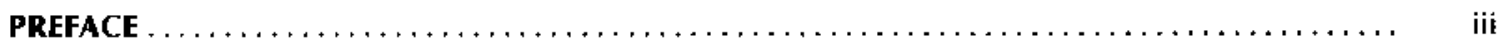

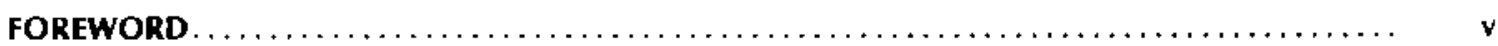

ATMOSPHERIC STUDIES IN COMPLEX TERRAIN

Atmospheric Diffusion in Complex Terrain

Model Simulation of Plume Dispersion in a Narrow Valley After Sunrise, D.C. Bader

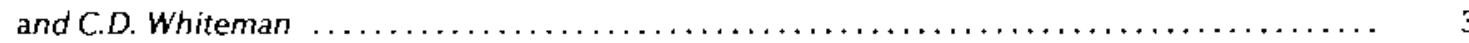

Coupling/Decoupling of Synoptic and Valley Circulations

Solar Radiation Fields in Areas of Complicated Terrain, K.J. Allwine and C.D. Whiteman ....... 9

Evening Transition in Colorado's Eagle Valley, C.D. Whiteman . . . . . . . . . . . . . . . 11

Atmospheric Boundary Layer Studies

PNL. Studies of the Turbulence Structure of Nocturnal Slope Flow, T.W. Horst

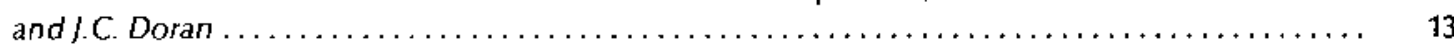

Surface Heat Fluxes During the 1984 Brush Creek Field Study, J.C. Doran and J.M. Hubbe . .... 15

LARGE-SCALE ATMOSPHERIC TRANSPORT AND PROCESSING OF EMISSIONS

PRECP/Nonlinearity/Scavenging Studies

PRECP Progress at PNL During FY-1986, W.G.N. Slinn, K.M. Busness, M.T. Dana,

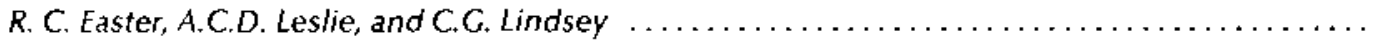

PNL'S Contribution to the PRECP-III (Syracuse) Field Studies, C.C. Lindsey, K.M. Busness,

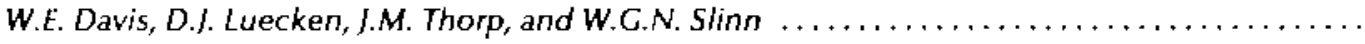

PNL'S Contribution to PRECP-IV (GALE) Field Studies, A.C. Leslie, K.M. Busness, M.T. Dana,

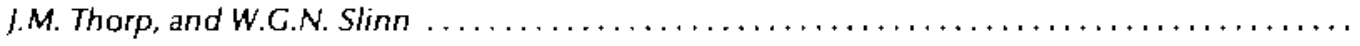

\section{Soviet Accident Fallout Measurements}

Field Studies of the Atmospheric Processing of Radionuclides Re!eased at Chernobyl,

W.G.N. Slinn, R.L. Brodzinski, K.M. Busness, M.T. Dana, W.E. Davis, C.E. Elderkin,

W.K. Hensley, E.A. Lepel, A.C.D. Leslie, R.W. Perkins, D.E. Robertson, J.M. Thorp,

I.A. Young, I.F. Boatman, L.R. Gunter, R.R. Dickerson, M. Kritz, and A. Schanot ........... 55

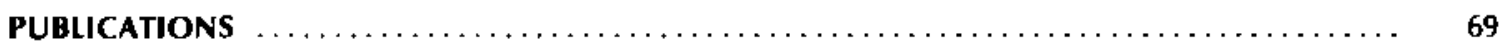

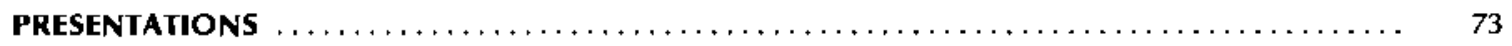

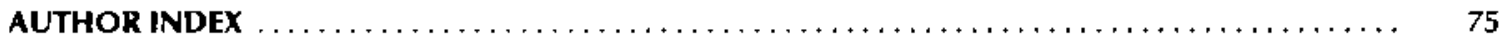

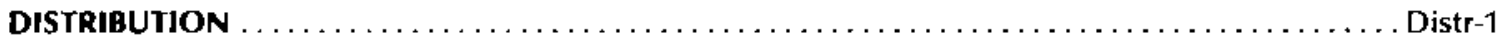


. 
Atmospheric Studies in Complex Terrain 


\title{
ATMOSPHERIC STUDIES IN COMPLEX TERRAIN
}

\author{
- Atmospheric Diffusion in Complex Terrain
}

\section{- Coupling/Decoupling of Synoptic and Valley Circulations}

\section{- Atmospheric Boundary Layer Studies}

Analysis of the transport and fate of contaminants in areas of mountainous terrain is especially difficult and uncertain. The large reserves of energy resources in such regions underscore the importance of developing realistic descriptions of atmospheric circulations and the dispersion of contaminants within and above complex terrain features. The Atmospheric Studies in Complex Terrain (ASCOT) research is approaching this problem from a fundamental standpoint.

The three PNL projects contributing to ASCOT jointly investigate radiative energy transfer at the surface, turbulent transfer properties, the resulting thermally driven circulations, their linkage with the general flow above terrain features, and the contaminant transport and dispersion properties that vary widely over time and space. Because of the magnitude and complexity of experiments undertaken, the ASCOT studies are planned and conducted cooperatively with other laboratories. Analysis and modeling efforts are also coordinated among the laboratories, leading to joint publications with other laboratory and contributing university scientists.

As ASCOT extends to larger scales of interest, numerical model simulations become especially important. Numerical experiments will contribute to understanding these more extensive and complex flows as simulations are performed interactively with selective field measurements. Ultimately, as confidence in the generic nature of the model grows, this technology will become particularly useful for facility siting and emergency response purposes related to energy developments in regions of non-uniform terrain. 



\section{- Atmospheric Diffusion in Complex Terrain}

Objectives of this study are:

To contribute to the development of multilaboratory long-range technical plans for studying the dispersion and transport of pollutants over complex landforms.

To collect and analyze field data as input and confirmation data for model prediction and for describing transport and diffusion phenomena in complex terrain.

To develop models of the transport and diffusion of pollutants over various complex terrain landforms during different phases of the diurnal cycle.

MODEL SIMULATION OF PLUME DISPERSION IN A NARROW VALLEY AFTER SUNRISE

D. C. Bader and C. D. Whiteman

Understanding the evolution of the daytime boundary layer in narrow mountain valleys is important in predicting the behavior of air masses in complex terrain. Our previous research into this phenomenon has produced conceptual models of daytime valley boundary layer evolution. These were developed from analysis of field data and numerical model results. In this paper, we report on numerical simulations of cross-valley plume dispersion in a strongly asymetrically heated valley and compare those results to measurements. We also use the model results to describe the boundary layer mechanisms responsible for the observed plume structure and to examine the effects of pollutant release height on cross-valley dispersion patterns.

The modeis used to support this research have heen developed over the past several years. Whiteman (1982) formulated a conceptual model of the morning destruction of the nocturnal stable layer based on observations taken in several valleys in western Colorado. In this model, the nocturnal layer is destroyed by two processes: the grawth of a convective houndary layer (CBL) above the valley surfaces and the subsidence of the stable air mass or "core" in the valley center as the slope flows transport mass from the CBL out of the valley. Whiteman and Mckee (1982) quantified the conceptual model with coupled thermodynamic equations that describe the time-dependent nature of these processes. Whiteman and Allwine (1985) expanded the thermodynamic model to develop an operational model of pollutant dispersion (VALMET) during the morning transition perior.

Subsequently, Bader and McKee (1983, 1985) used a nonhydrostatic primitive equation model to simulate the evolution of daytime boundary layers in a wide variety of valley configurations typical of those observed in western Colorado. Their results substantially supported the earlier conclusions of Whiteman and Mckee. However, they also identified a third process important to the removal of the nocturnal stable layer, i.e., the early morning recirculation of air warmed over the slopes into the remnants of the nocturnal stable layer. While the distribution of surface heating rate (or alternatively, albedo) with elevation was critical to the houndary layer development, the model simulations revealed that asymetries in heating between the opposing sidewalis at a given elevation had only minor effects. Vertical adjustments by small-scale gravity waves and cross-valley mixing within the stable layer quickly overcame any tendencies to form large potential temperature gradients across the boundary layer.

Field Measurements

To test the VALMET model, Whiteman et al. (1984) executed a series of tracer experiments during the 1982 ASCOT field program in the Brush Creek valley in western Colorado. The sunrise boundary-layer structure during these experiments was characterized by a 10 to $12 \mathrm{~K}$ potential temperature inversion in the lowest 100 to $200 \mathrm{~m}$ AGL topped by an isothermal layer extending to the ridge top. The nocturnal drainage flow formed a strong 5 to $8 \mathrm{~m} / \mathrm{s}$ jet at $100 \mathrm{~m}$ AGL with very weak flow ohserved near the ridge top. On the day 
of interest, August 4, $\mathrm{SF}_{6}$ was released continuously between 0428 and 0806 MST at an elevation of $105 \mathrm{~m}$ above the PNL site. The drainage wind carried the tracer down the valley and past the sampler arc near the valley mouth until about 0730 MST when the valley winds abruptly reversed to a weak up-valley flow through the valley depth. Recause of the valley's northwest-southeast orientation and the midsummer declination angle, the upper portion of the southwest sidewall was illuminated at around 0530 MST while the floor was first lit at 0643 MST. The northeast sidewall was shaded until nearly 0700 MST. Figure 1 shows tracer concentrations through the valley cross section where the sampler are was located. Near sunrise (Figure la), the plume was centered near the northeast sidewall approximately $100 \mathrm{~m}$ above the valley floor. By the time the
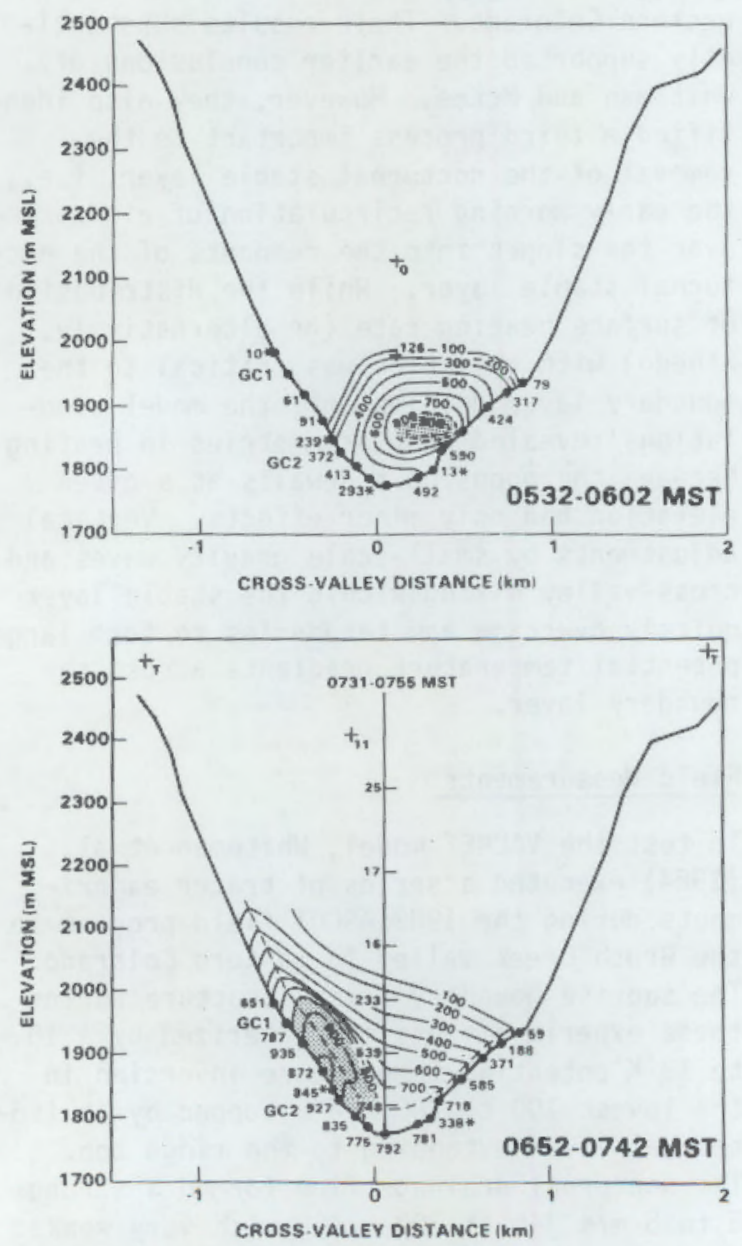

FIGURE 1. Valley Cross-Section Analyses of $\mathrm{SF}_{6}$ Concentrations (ppt) for August 4, 1982. valley wind reversed, the highest concentrations were found in the slope layer over the lower section of the southwest sidewall (Figure 1b). This drift of the plume could be explained by the formation of a slope layer over the illuminated southwest sidewall while the opposite sidewall was still shaded. However, such an explanation brings into question the conclusion drawn from the earlier model studies, namely that asymetric heating distributions had little overall effect on the boundary layer evolution.

The Model

The nonhydrostatic, boundary-layer version of the Colorado State University's Regional Atmospheric Modeling System (RAMS) was adapted for this study. This version of the code incorporates many improvements to the original model described by Tripoli and Cotton (1982). A prognostic turbulent kinetic energy (TKE) scheme similar to that used by Yamada (1983) was added to improve the description of sub-grid-scale turbulent fluxes. Additional modifications are summarized by Tripoli and Cotton (1986) and Bader et a1. (1987) and are not repeated here. As was done in the earlier valley studies, the surface heat flux at a given surface point was prescribed to be a constant fraction $(\approx 20 \%)$ of the incident extraterrestrial solar radiation. The sparse vegetation and dry conditions permitted us to assume that the surface albedo was uniform along the valley cross section. The effects of shading and the time-dependent nature of the solar illumination were also included in the surface heating function.

There were no initial cross-valley winds and there was no along-valley flow specified through the plane of the simulation. However, the turbulent effects of an alongvalley wind were included at the lower boundary. Two circular plumes with Gaussian concentration distributions were located above the valley axis with centerlines at 125 and $625 \mathrm{~m} \mathrm{AGL}$. The lower plume represented the onserved tracer plume while the upper one was added to determine the dispersion characteristics of the more elevated isothermal layer.

\section{Model Results}

The initial plume and thermal structure are shown in Figure $2 a$. To make the features 

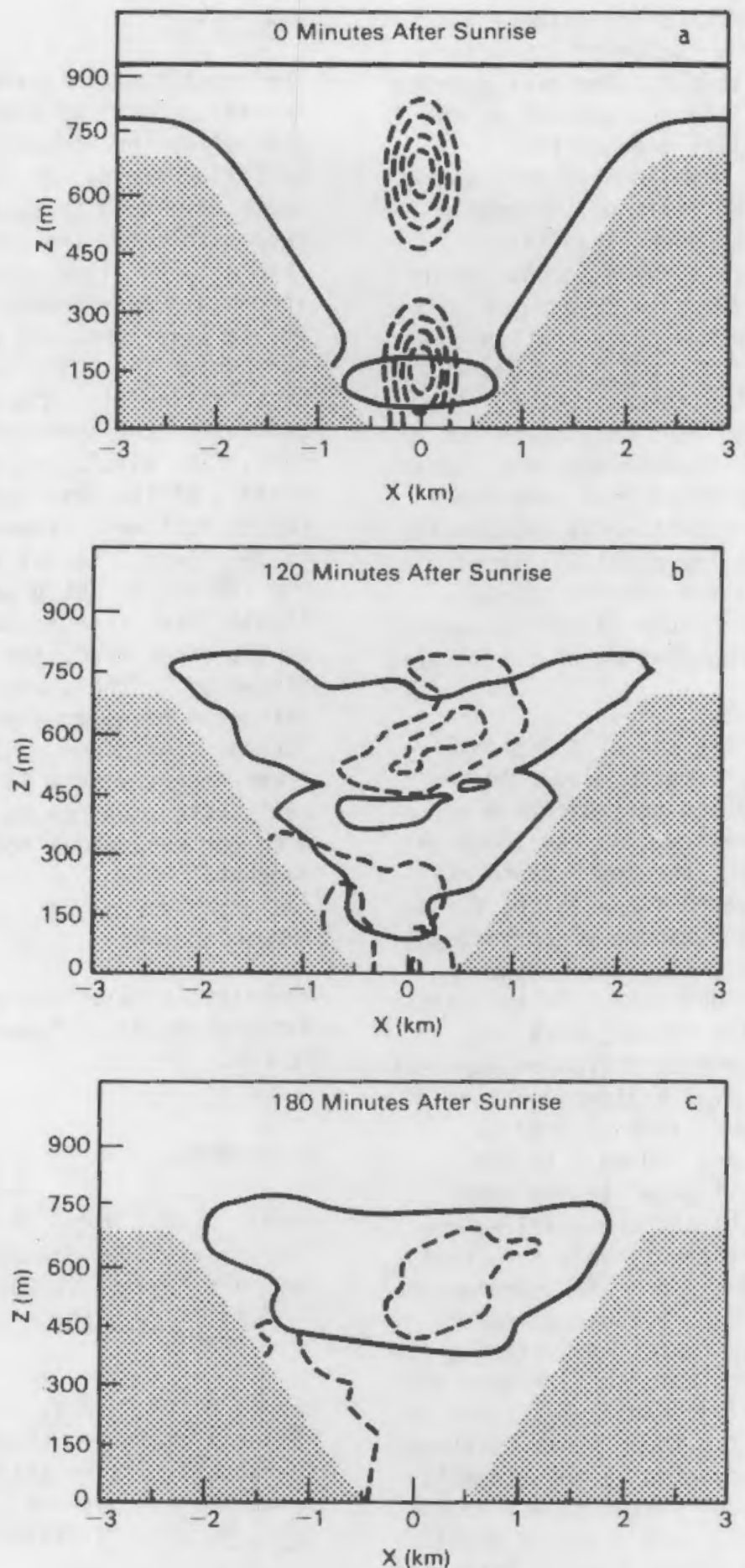

FIGURE 2. Valley Cross-Section Analyses of Model Output Showing Both Model Plumes (dashed line) and Stable Core (solid line): a) sunrise, b) $2 \mathrm{~h}$ after sunrise, and c) $3 \mathrm{~h}$ after sunrise. 
more visible, the vertical coordinate has been exaggerated by a factor of 3.5 with respect to the horizontal. The area bounded by the outer solid line corresponds to the region with a stability greater than $0.008 \mathrm{~K} / \mathrm{m}$, which we have adopted as a working definition of the limit of the stable core. A region of stronger stability $(0.016 \mathrm{k} / \mathrm{m})$ is indicated by a second solid line in the lowest $200 \mathrm{~m}$ in accordance with observations. The plume concentration contours are shown for $10 \%, 20 \%, 30 \%$, and $40 \%$ of the initial centerline concentration. The maximum contour shown in this case is $40 \%$ of the centerline value because the high concentrations can only be found in a very small region. Using this structure as the sunrise state of the valley, the model initiated surface heating, and the daytime boundary layer development and plume dispersion were simulated until the completion of the morning transition period.

Soon after sunrise, the top of the stable core was located at ridgetop elevation because of surface heating and advection of warm air above the valley. As was found in the tracer experiment, the lower plume migrated toward the heated slope in the first hour after sunrise and became mixed through the shallow CBL over that slope. However, the upper plume remained intact in the stable layer above the valley center, with only a small amount of horizontal diffusion apparent in the simulation. By $2 \mathrm{~h}$ after sunrise (Figure 2b), the lower plume started to travel up the southwest sidewall in the 0.5 to $1.0 \mathrm{~m} / \mathrm{s}$ slope flow while the upper plume was distorted by the cross-valley motions that kept the thermodynamic structure nearly symmetric. The top of the stable core acquired a concave shape because of subsidence over the valley center compensating for the mass lost in the slope flow. Figure $2 \mathrm{c}$ shows the boundary layer and plume structure $3 \mathrm{~h}$ after sunrise. The lower plume continued to be diffused and advected up the sidewall with the upper plume diffusing slowly in the remnants of the stable core atop the growing CBL. Thirty minutes later, the CBL entrained the upper plume, mixed it through the depth of the valley, and ventilated it to the boundary layer above the valley.

\section{Conclusions}

The results of this simulation revealed several aspects of the relationship between the valley thermodynamic structure and the mass flow field. It confirmed earlier concepts developed to explain the mechanisms responsible for the destruction of the valley stable layer after sunrise. Despite the strong asymmetric heating distribution, the stable layer remained nearly symmetric throughout the 3.5-h transition period. Cross-valley mixing and gravity wave motions maintained the symetric thermodynamic structure. The simulation also explained the details of the observed drift of the plume to the southwest sidewall and its advection up the slope. It was first entrained into the 150-m deep CBL growing at the base of the stable core, then advected up the sidewall. On the other hand, the upper plume slowly dispersed in the stable core, with lateral diffusion being greater than vertical diffusion. The plume centerline elevation decreased nearly $50 \mathrm{~m}$ in the second and third hours after sunrise in a manner consistent with our conceptual models of inversion descent.

\section{Acknowledgment}

Numerical simulations were performed at the National Magnetic Fusion Energy Computer Center.

\section{REFERENCES}

Bader, D. C., and T. B. McKee, 1983. "Dynamical Model Simulation of the Daytime Boundary Layer Development in Deep Mountain Valleys." J. Climate and App1. Meteor. $22: 341-351$.

Bader, D. C., and T. B. Mckee. 1985. "Effects of Shear, Stability and Valley Characteristics on the Destruction of Temperature Inversions." J. Climate and Appl. Meteor. 24:822-832.

Bader, D. C., T. B. Mckee and F. J. Tripoli. 1987. "Mesoscale Roundary Layer Evolution Over Complex Terrain. Part 1. Numerical Simulation of the Diurnal Cycle." Accepted for publication in J. Atmos. Sci. 
Tripoli, G. J., and W. R. Cotton. 1982. "The Colorado State University Cloud/Mesoscale Model-1981. Part I: General Theoretical Framework and Sensitivity Experiments." J. de Rech. Atmos. 16:185-219.

Tripoli, G. J., and W. R. Cotton. 1986. "An Intense, Quasi-Steady Thunderstorm Over Mountainous Terrain. Part IV: Three-dimensional Numerical Simulation." J. Atmos. Sci. 43:894-912.

Whiteman, C. D. 1982. "Breakup of Temperature Inversions in Deep Mountain Valleys. Part I: Observations." J. Appl. Meteor. $21: 270-289$.

Whiteman, C. D., and K. J. Allwine. 1985. VALMET - A Valley Air Pollution Model. PNL-4728 Rev. 1, Pacific Northwest Laboratory, Richland, Washington.
Whiteman, C. D., A. H. Huber, R. W. Fisher and B. D. Zak. 1984. "Atmospheric Tracer Experiments in a Deep Narrow Valley." Extended Abstracts, Fourth Joint Conference on Applications of Air Pollution Meteorology, American Meteorological Society, Boston, Massachusetts.

Whiteman, C. D, and T. B. McKee. 1982. "Breakup of Temperature Inversions in Complex Terrain. Part II: Thermodynamic Model." J. Appl. Meteor. 21:290-302.

Yamada, T. 19B3. "Simulations of Nocturnal Drainage flows by a $q^{2}-1$ Turbulence Closure Model." J. Atmos. Sci. 40:91-106. 



\section{- Coupling/Decoupling of Synoptic and Valley Circulations}

Objectives of this study are:

To conduct experiments to investigate and model mass and energy budgets that control the development and breakup of nocturnal valley circulations and their interactions with synoptic flow.

To develop simple predictive models for the coupling and decoupling of valley circulations from the overlying synoptic flows, and to use these models to produce improved environmental assessment models for complex terrain areas.

To provide scientific and technical support to the ASCOT program.

\section{SOLAR RADIATION FIELDS IN AREAS OF COMPLICATED TERRAIN}

\section{K. J. Allwine and C. D. Whiteman}

Radiative flux from the sun provides the main source of energy to the Earth, providing the energy that is utilized in life processes in the Earth's ecosystems and that drives the surface energy halance, the water cycle, and atmospheric and oceanic circulations. Calculations of solar radiation input to the Earth are a function of the changing spherical trigonometric relationships between the sun and the Earth as the Earth revolves in orbit about the sun. Calculations of solar flux are essential in disciplines such as forestry, meteorology, hydrology, architecture, and astronomy. Formulas for such calculations have been available for many years (e.g., Sellers 1965).

In this paper we present example results from a FORTRAN program, SOLAR, that we constructed from equations derived by previous investigators (Sellers 1965, Garnier and Ohmura 1968, and McCullough 1968) to calculate extraterrestrial solar flux. This program, documented in the journal Environmental Software (Whiteman and Allwine 1986), can be used to calculate extraterrestrial solar flux on planes of arbitrary inclination and azimuth angle at any point on the Earth's surface; thus, fields of solar flux can be calculated in areas of complicated terrain. The extraterrestrial solar flux calculations specify the flux at the "edge" of the Earth's atmosphere. Those who wish to calculate solar flux at the Earth's surface may wish to expand the model to account for depletion of the solar beam by absorption, reflection, and refraction as it traverses the Earth's atmosphere.
The SOLAR program was developed as part of our ASCOT activities to document an approach being used to compute the components of the radiation and surface energy budgets in Colorado's Brush Creek Valley. Energy budget calculations are being made for this complex terrain area as part of the analysis of a major DOE field experiment conducted in the valley in 1984 .

The first example application of SOLAR shows instantaneous extraterrestrial solar flux throughout the course of a day. Figure 1 illustrates the results of a simulation of SOLAR made at a number of different latitudes, $\emptyset$, on December 22, the northern nemisphere's winter solstice. The figure

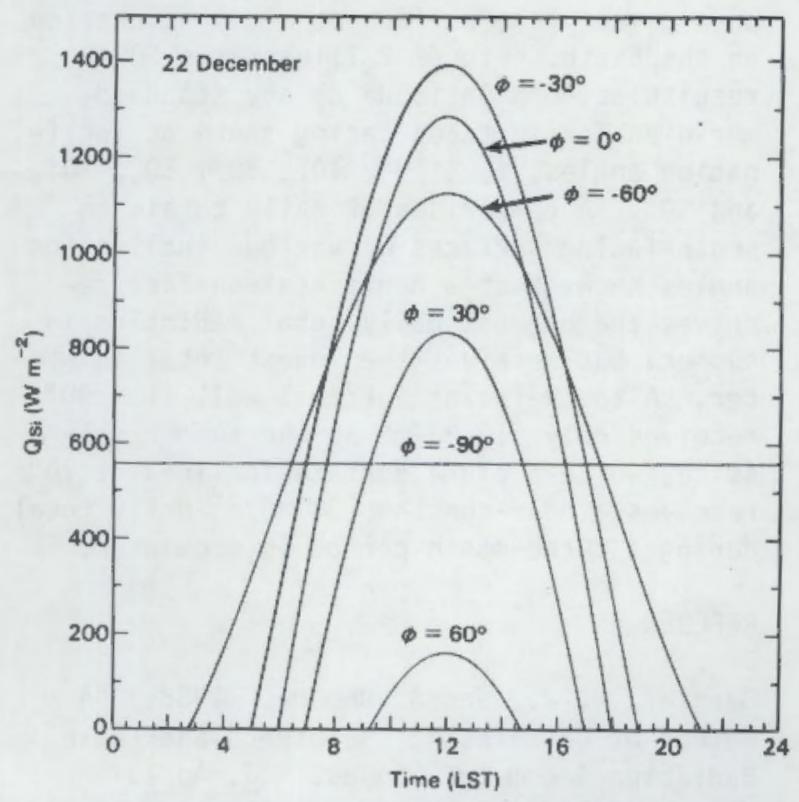

FIGURE 1. Instantaneous Extraterrestrial Solar Flux as a Function of Time on December 22, for Latitudes $60^{\circ} \mathrm{N}$, $30^{\circ} \mathrm{N}, 0^{\circ}, 30^{\circ} \mathrm{S}, 60^{\circ} \mathrm{S}$, and $90^{\circ} \mathrm{S}$. 
represents the course of instantaneous radiation on any standard meridian at the latitude indicated. Standard meridians are at longitudes of $\pm 15^{\circ} \cdot n$, where $n$ is an integer from 0 to 12. Sites not on a standard meridian will have the same course of radiation but, in terms of clock time, will experience sunrise and sunset 4 minutes earlier for every degree of longitude east of the standard meridian. At the North Pole $\left(6=90^{\circ}\right)$ the sun does not rise during the polar night, so that daily total solar flux is zero. At $60^{\circ} \mathrm{N}$ a short day is experienced, with the sun rising at 0913 LST and setting at 1444 LST. The short period of daylight provides daily total radiation of only $2.1 \mathrm{MJ} / \mathrm{m}^{2}$. Days become longer as one travels farther south, and daily totals increase, Daily totals of $19.5,35.3$, and $43.5 \mathrm{MJ} / \mathrm{m}^{2}$ are experienced at $30^{\circ} \mathrm{N}$, at the equator, and at $30^{\circ} \mathrm{S}$, respectively. The daylight period continues to increase as the South Pole is approached, but peak instantanegus radiation decreasęs from nearly $1390 \mathrm{~W} / \mathrm{m}^{2}$ at $30^{\circ} \mathrm{S}$ to $1123 \mathrm{~W} / \mathrm{m}^{2}$ at $60^{\circ} \mathrm{S}$ and to $556 \mathrm{~W} / \mathrm{m}^{2}$ at the South Pole $\left(\phi=-90^{\circ}\right)$. Instantaneous solar flux at the South Pole is constant at $556 \mathrm{~W} / \mathrm{m}^{2}$ throughout the entire polar day as the sun circles overhead at a zenith angle of $66.5^{\circ}$.

The second example application of SOLAR shows the variation in daily totals of extraterrestrial radiation through the course of a year on a given plane surface at a given location on the Earth. Figure 2 illustrates SOLAR results at $40^{\circ} \mathrm{N}$ latitude on any standard meridian for surfaces facing south at inclination angles, $i$, of $0^{\circ}, 10^{\circ}, 30^{\circ}, 50^{\circ}, 70^{\circ}$, and $90^{\circ}$. A comparison of daily totals on south-facing surfaces of various inclination angles shows that a horizontal surface receives the highest daily total radiation in summer, but receives the lowest total in winter. A south-facing vertical wall $\left(i=90^{\circ}\right)$ receives only $6.9 \mathrm{MJ} / \mathrm{m}^{2}$ at the sumner solstice, while a plane surface inclined at $70^{\circ}$ receives a near-constant $38 \mathrm{MJ} / \mathrm{m}^{2}$ daily total during a three-month period in midwinter.

\section{REFERENCES}

Garnier, B. J., and A. Ohmura. 1968. "A Method of Calculating the Direct Shortwave Radiation Income of Slopes." J.Appl. Meteor. 7:796-800.

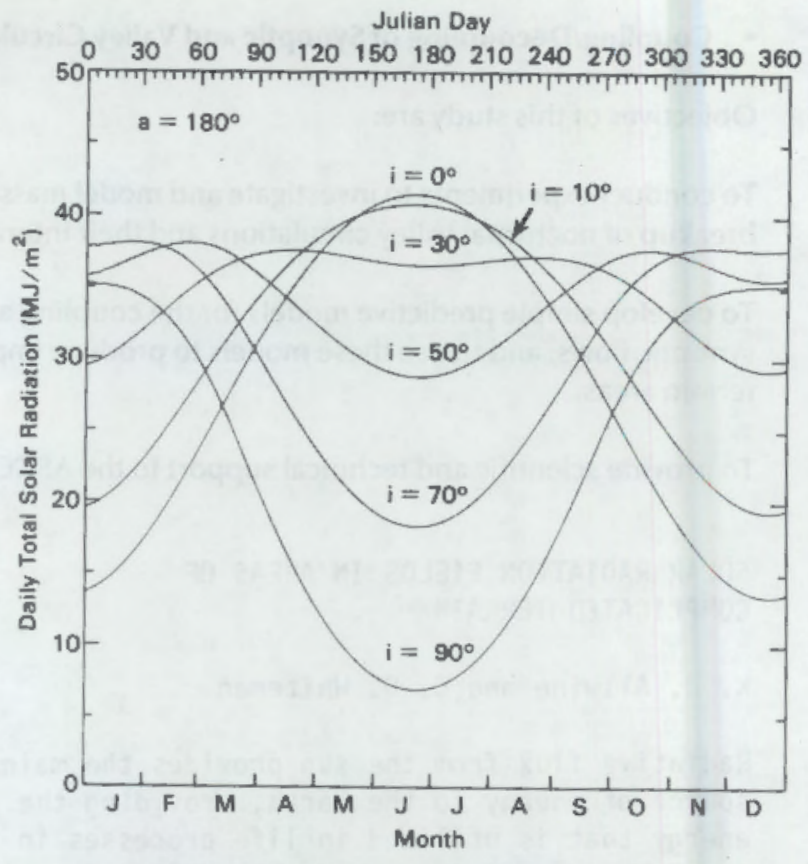

FIGURE 2. Daily Totals of Extraterrestrial Solar Flux on a South-Facing Plane Surface During the Course of a Year. Totals are shown for plane surfaces of inclination $0^{\circ}, 10^{\circ}$, $30^{\circ}, 50^{\circ}, 70^{\circ}$ and $90^{\circ}$.

McCullough, E. C. 1968. "Total Daily Radiant Energy Available Extraterrestrially as a Harmonic Series in the Day of the Year." Arch. Meteor. Geophys. Biokl. Ser. B $16: 129-143$.

Sellers, W. D. 1965. Physical Climatology. Iniversity of Chicago Press, Chicago, Illinois.

Whiteman, C. D., and K. J. Allwine. 1986. "Extraterrestrial Solar Radiation on Inclined Surfaces." Environmental Software, 1(3):164-169. 


\section{EVENING TRANSITION IN COLORADO'S EAGLE VALLEY}

\section{D. Whiteman}

The buildup of temperature inversions and the development of nighttime local wind systems is of increasing interest in studies of air pollution potential in complex terrain areas. observations of changes in atmospheric structure, which take place in the late afternoon and evening, allow the investigation of physical mechanisms by which mass and thermal energy are transferred in the valley atmosphere. These atmospheric processes were investigated in Colorado's Eagle Valley using tethered balloon observations, and initial conclusions were made concerning the mass and thermal energy transfers in the valley atmosphere. A recent paper (Whiteman 1986) documents the field study and analyses. A summary of the experiment and results is presented here.

Case Study of October 15, 1978

Tethered balloon profiles taken in the $700-m-$ deep Eagle Valley during a 4-h period in the afternoon and evening of October 15, 1978, illustrate the normal evolution of valley temperature and wind structure during inversion formation (Figure 1). Skies were clear and the atmosphere was undisturbed during the observational period.

Observations were taken from the valley floor near Edwards, Colorado, where the valley floor is $1450 \mathrm{~m}$ wide and the sidewall slopes are $10^{\circ}$ (south-facing slope) and $21^{\circ}$ (northfacing slope).

\section{Summary of Results}

Temperature inversion buildup began about $45 \mathrm{~min}$ before astronomical sunset (i.e., at 1630 MST). The depth of the inversion increased rapidly, with average growth rates of $250 \mathrm{~m} / \mathrm{h}$ during the first $1.5 \mathrm{~h}$ of the inversion buildup period. The inversion extended through the entire valley depth by 2000 to 2100 MST. Using a simple mathematical technique, we calculated the mean rate of loss of energy from a $1-m-t h i c k$ cross section of the valley atmosphere during the $4-h$ inversion buildup period to be $1.23 \mathrm{MW}$. The energy loss may result from a number of physical processes including sensible heat flux
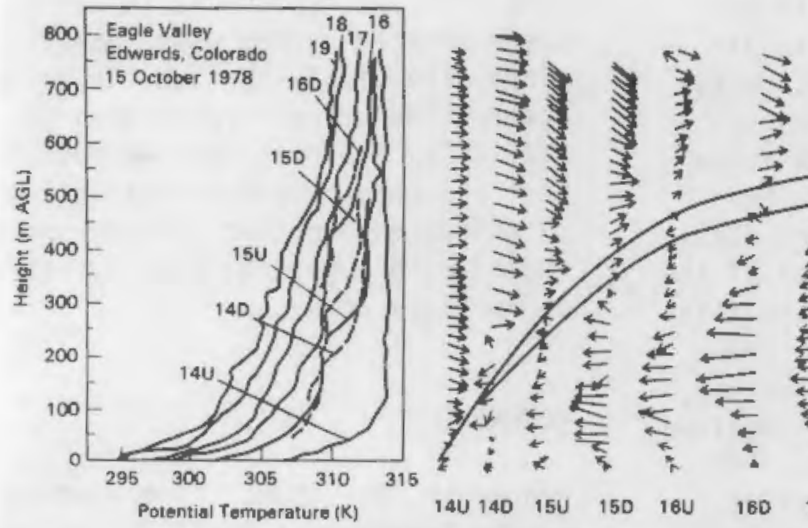

\begin{tabular}{|c|c|c|c|c|c|}
\hline$*$ & Time (MST) & $*$ & Time (MST) & $*$ & Time (MST) \\
\hline $14 \mathrm{U}$ & $1702-1720$ & $16 \mathrm{U}$ & $1831-1847$ & $1 \mathrm{aU}$ & $2000-2018$ \\
\hline $14 \mathrm{D}$ & $1720-1738$ & $16 \mathrm{D}$ & $1847-1901$ & $18 \mathrm{D}$ & $2018 \cdot 2033$ \\
\hline $15 \mathrm{U}$ & $1746-1803$ & $17 \mathrm{U}$ & $1914-1931$ & $19 \mathrm{U}$ & $2043-2102$ \\
\hline 150 & $1803-1822$ & 170 & $1931-1945$ & 190 & $2102-2116$ \\
\hline
\end{tabular}

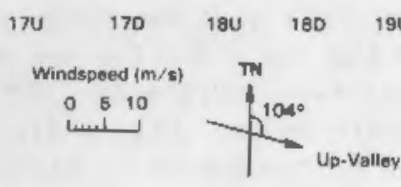

FIGURE 1. Sequential Tethered Balloon Profiles of Potential Temperature and Winds During the Evening of October 15, 1978, in the Eagle Valley. Vector winds are plotted as a function of height; vector lengths correspond to wind speeds (see wind speed legend). The up-valley direction is given for reference. The time intervals over which the up (U) and down (D) soundings were conducted are given in the table. The solid lines in the wind profiles delineate the boundaries of the wind transition layer. 
divergence, radiative flux divergence, and cold air advection by the down-valley and downslope flows. Redistribution of the cooling within the valley may also be accomplished by vertical motions (Hennemuth 1986).

Special analyses were conducted to identify the most important physical processes leading to the evolution of the wind and temperature structure during the evening transition period. These analyses focused on the propagation of special structural features identified in the tethersonde soundings and on calculations of the rate of loss of thermal energy from the valley. A zone of maximum rate of energy loss propagated upward from the valley floor after 1630 MST and was accompanied by distinctive structures in both the temperature and wind fields. A persistent zone of intense stability was observed at the top of the growing inversion layer. This inversion cap corresponded in height to a wind reversal zone. The zone itself was characterized by weak winds of variable direction. Below this ascending zone were strong (up to $7-m / s$ ) down-valley winds, while above it up-valley winds persisted. The temperature jump at the inversion cap weakened as the cap ascended. A zone of strong cooling under the inversion cap appears to be best explained by ascent of the cap itself (i.e., temperatures change because of vertical advection). The rising of the cap requires that there be mass convergence below the cap. This mass convergence could be caused by convergence of the downslope flows from the two sidewalls below the level of the inversion cap. A well-developed cross-valley flow occurred in a constant potential temperature layer just below the inversion cap, suggesting that the mass convergence required for inversion cap ascent occurs here. This observation suggests that downslope flows separate from the two sidewalls and produce horizontal mass flux convergence just below the rising inversion top (Figure 2). This process should be thought of as discontinuous or stochastic, since the slope flows would not be expected to flow out into the valley center as a steady stream. Thus, we

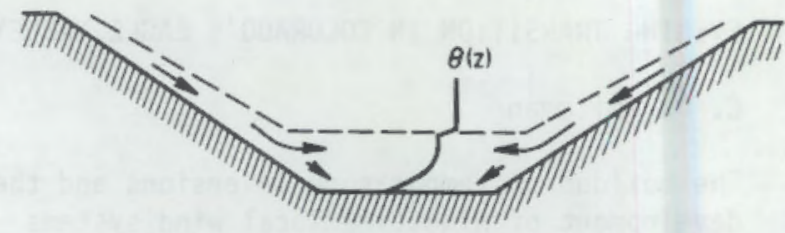

FIGURE 2. Mass Convergence Below the Inversion Cap from the Slope Flow Layers.

tentatively conclude that, during the inversion buildup period, downslope flows are not continuous. That is, parcels of air carried in the downslope flows high on the sidewalls are typically not carried all the way down the slope to the valley floor to converge near the center of the valley floor. Rather, parcels in the downslope flow layers are mixed into the inversion layer from the valley slope flows when they attain their level of buoyancy equilibrium. This mixing occurs just below the inversion cap because the parcels encounter a sudden temperature jump (increase) when descending through the level of the rising inversion cap.

The implications of the above hypothesis for air pollution dispersion in valleys during the evening transition period seem significant. If the hypothesis is correct, pollutants emitted in the downslope flows will be mixed effectively through the valley volume rather than being carried down the slopes to the valley floor. Thus, we suggest that further and more complete observational programs be conducted and that simulations be performed with numerical models that include the appropriate physics.

\section{REFERENCES}

Hennemuth, B. 1986. "Temperature Field and Energy Budget of a Small Alpine Valley." Contrib. Atmos. Phys. 58(4):545-559.

Whiteman, C. D. 1986. "Temperature Inversion Buildup in Colorado's Eagle Valley." Meteorology and Atmospheric Physics, 35:220-226. 


\section{- Atmospheric Boundary Layer Studies}

Objectives of this study are:

To determine experimentally the mean and turbulence characteristics of gravity controlled slope and valley flows.

To develop appropriate analytical, numerical, and graphical representations of the principal features of such flows.

To describe features of boundary-layer energy budgets driving pollutant transport and diffusion in slope and valley winds.

To formulate and verify economical predictive models for these features.

PNL STUDIES OF THE TURBULENCE STRUCTURE OF NOCTURNAL SLOPE FLOW

T. W. Horst and J. C. Doran

Some preliminary ideas on the turbulence structure of nocturnal slope flows were formulated from observations at The Geysers and Rattlesnake Mountain field sites in 1980 and 1981 (Horst and Doran 1986a). As a consequence of the low-level maximum in the downslope wind speed, the shear production term in the slope flow TKE budget can change rapidly over a small vertical extent, and the vertical distribution of turbulence can differ significantiy from that found in nocturnal flows over flat terrain. The TKE in slope flow need not be a monotonic function of height, but can vary in a complex manner, depending on the local shears arising from the interaction of katabatic and ambient winds. In particular, in the region of the maximum in the downslope wind component, the turbulence production can become quite small and a local minimum may occur in the TKE.

A detailed analysis of the turbulence structure of nocturnal slope flow was therefore initiated with funding from the Geosciences Division of the U.S. Army Research Office. Turbulence data were collected at the Rattlesnake Mountain slope wind site during the summer and fall of 1983, and the structure of turbulence in slope flow was compared to that. found over flat terrain. These results have been reported at the Third Conference on Mountain Meteorology (Doran and Horst 1984), at the Seventh Symposium on Turbulence and Diffusion (Horst and Doran 1985), and in a final report to the Army Research Office (Doran and Horst 1985).

The minimus in TKE at the height of the slope flow wind maximum, the change in the sign of the momentum flux at that height, and the presence of stable stratification suggested that slope flow turbulence above the wind maximum may be decoupled from the surface and have a local structure similar to that found by Nieuwstadt (1984) for stably stratified flow over flat terrain. Using the turbulence covariance model developed by Brost and Wyngaard (1978), Nieuwstadt found that turbulence variables obey a local scaling hypothesis in which dimensionless combinations of variables measured at a given height $z$ can be expressed as functions of a single independent parameter $z / A$. Here $A$ is a local Obukhov length defined in terms of the local values of the momentum and heat fluxes, rather than their surface values. Thus, Nieuwstadt proposed that the turbulence structure is locally self-similar, while the vertical profiles of turbulence variables depend on the vertical distributions of the momentum and heat fluxes.

Local similarity of the turbulence structure requires a local balance between turbulence production and destruction. That is, turbulence flux divergence and the consequent spatial transfer of turbulence from one location to another should not play a significant role in the budgets of the turbulence second moments. The contribution of turbulence flux divergence to the slope flow TKE budget was determined from the 1983 Rattlesnake Mountain data. Above the low-level wind maximum, the slope flow TKE budget was found to be essentially a local balance between shear production and viscous dissipation, with only a minor role played by TKE flux divergence. The contribution of buoyant production to the TKE budget was found to be negligible (Horst and Doran 1985).

During the past year, the study of the turbulence structure of nocturnal slope flow has 
been continued within the DOE Atmospheric Boundary Layer studies program. Assuming negligible turbulence flux divergence, we used the turbulence covariance model of Brost and Wyngaard (1978) to predict local turbulence scaling for slope flow (Horst and Doran 1986b). The buoyancy terms in the slope flow turbulence equations were found to differ from those for flat terrain because the mean flow direction is not horizontal, i.e., normal to the direction of gravity. As a consequence, the turbulence scaling for slope flow includes as additional variables the slope angle and the directions of the wind shear, the momentum flux vector, and the slope-parallel heat flux. Nevertheless, the model predicts that slope flow turbulence variables, scaled with the local values of the momentum and heat fluxes, are nearly identical to those for stably stratified flow over flat terrain, the principal exception being the normalized eddy diffusivities.

The model results for slope flow have been compared with the turbulence data collected on Rattlesnake Mountain, and the comparison suggests that local scaling is a promising approach for the description of turbulence in slope flows. Doran and Horst (1984) found the slope flow TKE to be proportional to the local shear stress, in agreement with the model predictions and consistent with a TKE budget that is essentially a local balance between shear production and viscous dissipation. As predicted by the model, the ratio of TKE to shear stress observed for slope flow is in close agreement with those observed for flat terrain. The observations also support the prediction of local scaling that the normalized eddy diffusivities above the slope flow wind maximum can be considerably larger than for stably stratified flow over flat terrain (Figure 1 ).

Based on the encouraging comparison of the Rattlesnake Mountain slope flow data to the model predictions, the model results have also been investigated for a variety of slope angles and wind directions. The dimensionless eddy diffusivities are predicted to increase with slope angle above the wind maximum and to be largest for pure downslope flow. Below the wind maximum, the eddy diffusivities are predicted to be essentially unchanged, except for a small increase for cross-slope flow. The increased turbulent transport above the wind maximum is directly

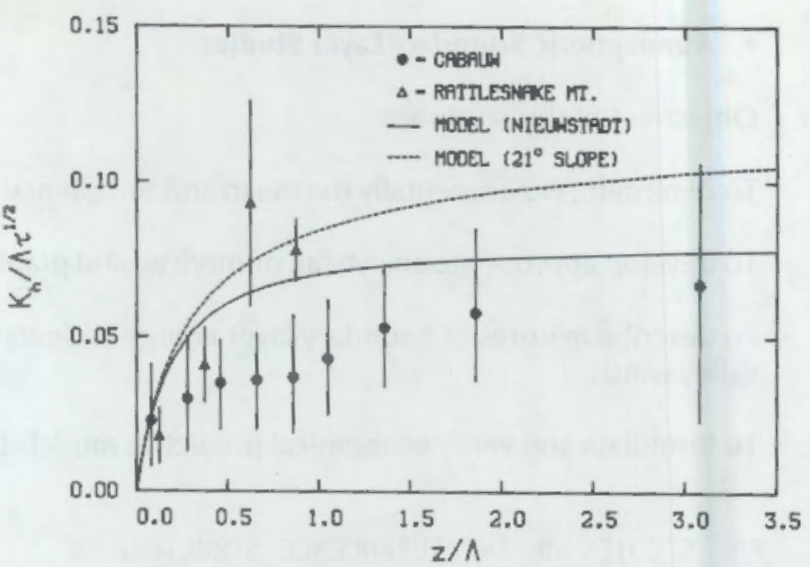

FIGURE 1. The Eddy Diffusivity for Heat $K_{h}$, Normalized with $\Lambda$ and the Local Shear Stress, $\tau$, as a Function of $z / \Lambda$.

related to an additional buoyancy term in the TKE budget that is proportional to the slopeparallel heat flux. Above the wind maximum, the slope-parallel heat flux is upslope. This reduces $R f$, the ratio of buoyant suppression to shear production in the TKE budget, and thus increases the TKE and the turbulent transport.

\section{REFERENCES}

Brost, R. A., and J. C. Wyngaard. 1978. "A Model Study of the Stably Stratified Planetary Boundary Layer." J.Atmos. Sci. 35: 1427-1440.

Doran, J. C., and T. W. Horst. 1984. "Turbulence Structure of Nocturnal Slope Winds." In Proceedings of the Third AMS Conference on Mountain Meteorology, Portland, Oregon. American Meteorological Society, Boston, Massachusetts.

Doran, J. C., and T. W. Horst. 1985. Turbulent Structure of Stably Stratified Nocturnal Slope Flows. Final Report to the U.S. Army Research Office, Battelle, Pacific Northwest Laboratories, Richland, Washington.

Horst, T. W., and J. C. Doran. 1985. "A Turbulent Kinetic Energy Budget in Nocturnal Slope Flow." In Proceedings of the Seventh AMS Symposium on Turbulence and Diffusion, Boulder, Colorado. American Meteorological Society, Boston, Massachusetts. 
Horst, T. W., and J. C. Doran. 1986a. "Nocturnal Drainage Flow on Simple Slopes." Bound. Layer Met. 34:263-286.

Horst, T. H., and J. C. Doran. 1986b. "The Turbulence Structure of Nocturnal Slope Flow." Submitted to J. Atmos, Sci.

Ni euwstadt, F. T. M. 1984. "The Turbulent Structure of the Stable, Nocturnal Boundary Layer." J. Atmos. Sci. 41:2202-2216.

SURFACE HEAT FLUXES DURING THE 1984 BRUSH CREEK FIELD STUDY

J. C. Doran and J. M. Hubbe

As part of the ASCOT experiment in the fall of 1984, four laboratories [PNL, the Wave Propagation Laboratory (WPL), Argonne National Laboratory (ANL), and the Atmospheric Turbulence and Diffusion Laboratory (ATDL)] measured surface eddy heat fluxes on the valley floor of Brush Creek. These measurements were intended to provide data that could be incorporated into energy budget calculations for the Brush Creek drainage system. Although the complex terrain, inhomogeneous surface cover, and generally limited fetch found in the vicinity of each of the measurement areas was expected to cause significant variations in heat fluxes from site to site, it was hoped that estimates could be made for representative flux values to be used in model and budget studies.

Data for two nights, those of September 25-26 and September 29-30, 1986, have been compared for each of the sites. As anticipated, there is considerable scatter in the results but some general features can be discerned (Figure 1). The maximum sensible heat flux to the surface occurred relatively early on each night, around 2000 to 2100 , Values of approximately 40 to $50 \mathrm{w} / \mathrm{m}^{2}$ seem typical, although deviations by more than a factor of two on either side were found. After this period the heat fluxes decreased to values perhaps $50 \%$ or less of the maximum values, and remained there for the duration of each night. There is some consistency to differences among sites, with the two sites that were farthest downvalley, PNL and ATDL, usually showing the smallest fluxes.

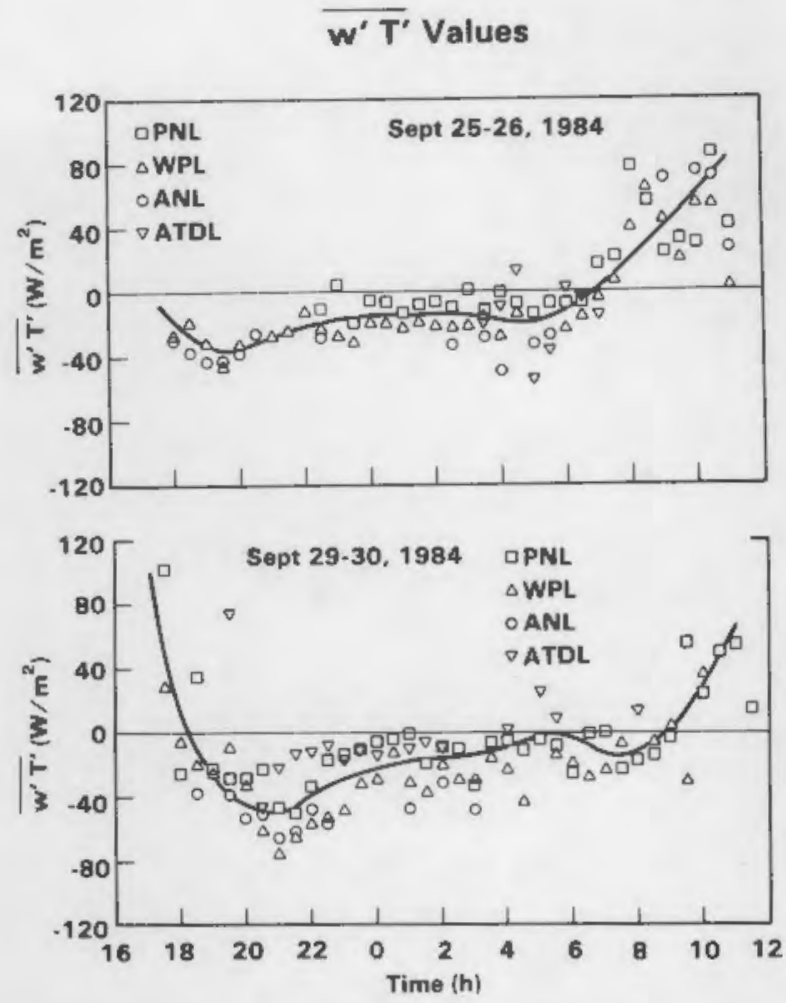

FIGURE 1. Heat Fluxes Measured at Four Sites in Brush Creek. The solid line is intended only as a rough guide to the trends of the data with time.

Because four laboratories used different data acquisition equipment, averaging times, and filtering procedures, the calculations of heat fluxes at each site were not identical. The differences in flux values introduced by such factors are not expected to be significant compared to the observed variations between sites. This expectation is supported by an examination of heat flux values deduced from Bowen ratio measurements taken at the PNL site where eddy flux data were also collected; the eddy flux and Bowen ratio values were similar. In addition, at the PNL site eddy heat fluxes were measured at heights of 3 and $10 \mathrm{~m}$. The trends in the fluxes at the two levels were similar, but the magnitudes of the fluxes at $3 \mathrm{~m}$ were somewhat higher than those at $10 \mathrm{~m}$. This behavior, in keeping with that expected in a stable boundary layer, provides additional confidence in the accuracy of the measurements. 



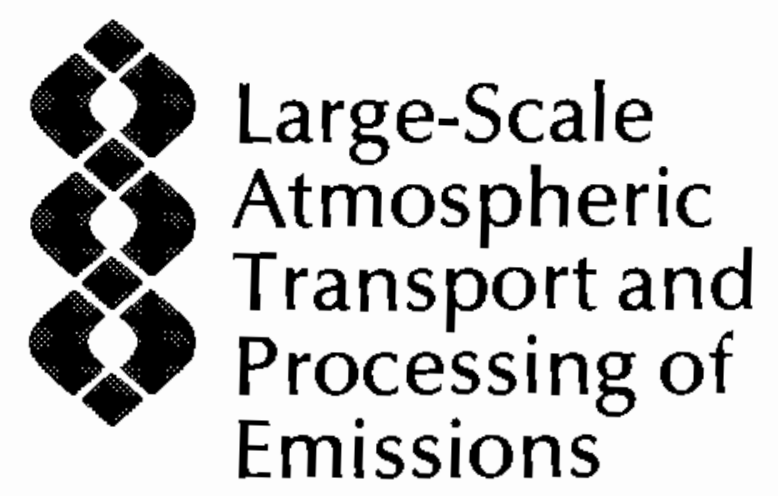




\title{
LARGE-SCALE ATMOSPHERIC TRANSPORT AND PROCESSING OF EMISSIONS
}

\author{
- PRECP/Nonlinearity/Scavenging Studies
}

\section{- Soviet Accident Fallout Measurements}

A major emphasis of the atmospheric sciences program at PNL is regional-scale acidic-deposition research conducted within DOE's Processing of Emissions by Clouds and Precipitation (PRECP) program. PRECP's primary objective is to provide essential information for the quantitative description of chemical wet deposition, as a function of air pollution loadings, geographic location, and atmospheric processing.

PRECP is administered and coordinated through the National Acid Precipitation Assessment Program (NAPAP), within its Atmospheric Processes task group. PRECP's scientific domain addresses those physical and chemical processes that occur within cloud and precipitation systems. Thus precipitation scavenging, aqueous-phase chemistry, and storm-chemistry climatology receive direct attention within PRECP. Because of the NAPAP's structure and goals, PRECP operates in a manner that is highly interactive with other internal scientific efforts, receiving information from, and feeding information to, other Task groups.

The prime contributors to PRECP are scientists at three national laboratories: Argonne National Laboratory (ANL), Brookhaven National Laboratory (BNL), and the Pacific Northwest Laboratory (PNL). Important contributions are also being made by scientists at Colorado State University (CSU), the University of Denver, the University of Maryland (U of MD), the State University of New York at Albany (SUNYA), the National Center for Atmospheric Research (NCAR), and the National Oceanic and Atmospheric Administration (NOAA) through subcontracts with PNL.

Another opportunity for investigating large-scale atmospheric transport and removal processes was presented through a special project of measurements following the Chernobyl reactor accident in April 1986 and the subsequent worldwide fallout of radioactive materials. The measurements from aircraft in air, clouds, and precipitation and at the surface in air, rain, surface water, and vegetation were designed to permit the quantitative evaluation of the content and character of the plume, the transport and spread of the plume in the atmosphere, the cloud processing and wet removal of the radioactive contaminants from the air, and the $\mathrm{dr}$ deposition of various radioactive species.

The radioactive content of the plume and associated meteorological parameters were measured during the movement of the plume across the western U.S. This comprehensive measurement effort during the limited period of the project would not have been possible without the participation of scientists and technicians from several PNL departments and from the following organizations:

- Atmospheric Environment Service of Canada (AES)

- National Aeronautics and Space Administration (NASA)

- National Atmospheric Deposition Program (NADP)

- Nationai Center for Atmospheric Research (NCAR), funded by the National Science Foundation (NSF)

- National Oceanic and Atmospheric Administration (NOAA)

- University of Maryland (U of MD).

These organizations quickly recognized the significance of the proposed measurement efiort and provided vital assistance in making the project a success. 



\section{- PRECP/Nonlinearity/Scavenging Studies}

Objectives of this study are:

To define and reduce current inadequacies in the mathematical modeling of the processing of emissions by clouds and precipitation through field, laboratory, theoretical, and statistical investigations.

To contribute, through observations, to understanding the processing of pollutants by clouds and precipitation.

To re-examine a significant portion of the substantial environmental data bases that relate to acidic deposition for indications of nonlinearities.

PRECP PROGRESS AT PNL DURING FY-1986

W. G. N. Slinn, K. M. Busness, M. T. Dana, R. C. Easter, A. C. D. Leslie, C. G. Lindsey

Two dominant features of the acid rain problem in the United States are revealed in Figures 1 and 2. Figure 1 locates eastern states on a plot of emissions of sulfur (S), mostly as $\mathrm{SO}_{2}$, versus deposition of $\mathrm{S}$, mostly as $\mathrm{SO}_{4}=$, in precipitation; for example, the wet deposition flux of $S$ in Florida (less

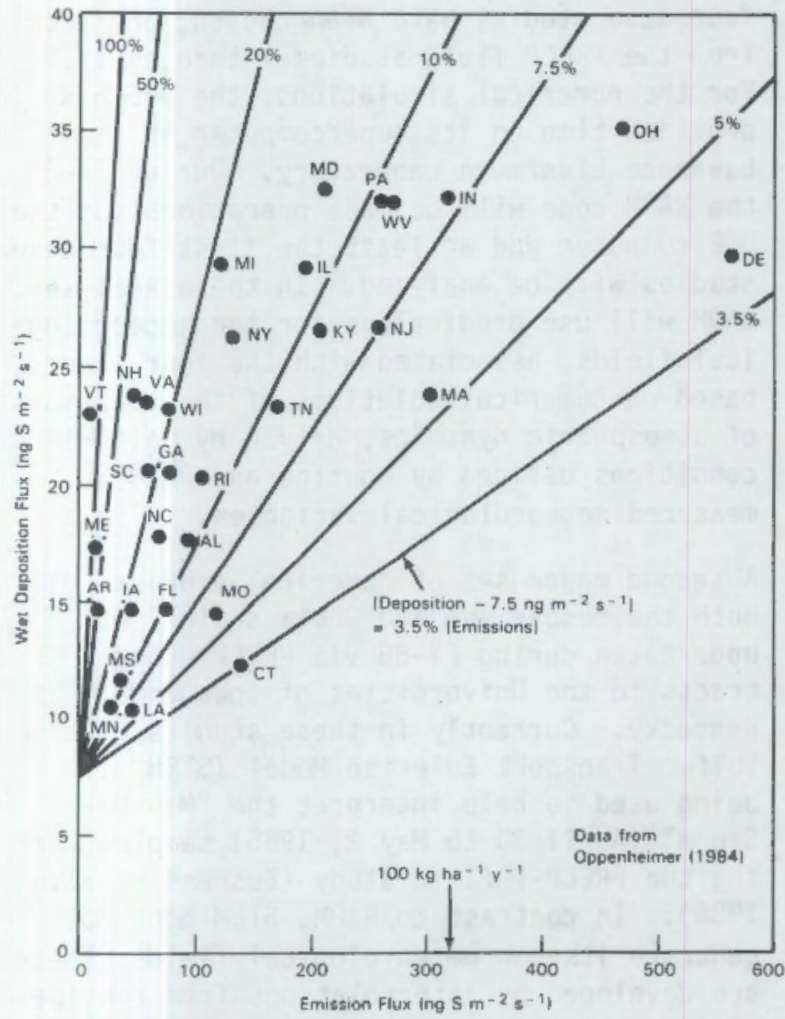

FIGURE 1. State-Wide Emission Fluxes of $\mathrm{S}$ as $\mathrm{SO}_{2}$ and WetDeposition Fluxes of $\mathrm{S}_{\text {as }} \mathrm{SO}_{4}=$ [Based on EPA Emission Inventories and MAP3S, NADP, and UAPSP Network Data, as Summarized by Oppenheimer (1984)]. From Slinn (1987).

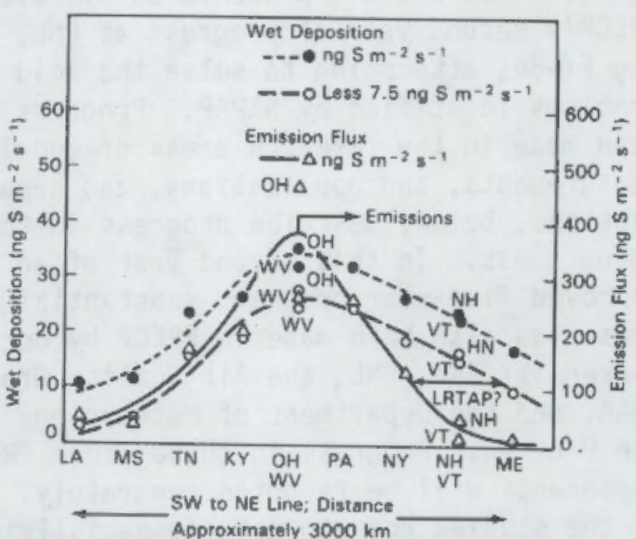

FIGURE 2. Plots of Emission and Wet Deposition Fluxes (and Wet Deposition Less $7.5 \mathrm{ng}-\mathrm{S} \mathrm{m}^{-2} \mathrm{~s}^{-}$) Along a SW to NE Line from Louisiana to Maine. From Slinn (1987).

what may be a "natura]" deposition flux of about $7.5 \mathrm{ng}-5 \mathrm{~m}^{-2} \mathrm{~s}^{-1}$ ) can be seen to be approximately 10 percent as much as Florida's emissions of $S$. In this plot (suggested by D. H. Slade, personal comunication, 1986), it is seen that, relative to emissions, the wet deposition flux of $S$ is substantially greater in most of the New England states (and in the Carolinas and Virginia) than in many of the Ohio River valley states.

Though more qualitative, Figure 2 is also revealing. It is a plot of both emissions and wet deposition of $S$ for states along a SW to NE line from Louisiana to Maine. It is of course true that the wind does not always blow in the direction of this line, but the line is a first approximation for the direction of air flows ahead of a substantial number of storms in the eastern U.S. The results suggest both the long-range atmospheric transport of $S$ pollution and the possibility that cloud processes responsible for wet deposition of S become "saturated" with sulfur species over the Ohio River valley (viz., the deposition curve of Figure 2 has a "flatter" top than the emission curve). Both 
of these features are also seen in similar plots for deposition versus emissions in nations of western Europe (Slinn 1987); differences between sulfur and nitrogen deposition will be suggested later in this report (cf. Figure 15).

Problems addressed by PRECP for NAPAP were given in last year's annual report, as were descriptions of PRECP's management structure and first year's progress (Siinn et al. 1986). This article presents an overview of PRECP's second year of progress at PNL, during $F Y-86$, attempting to solve the acid rain problems identified by NAPAP. Progress has been made in the research areas of modeling, measurements, and applications, and separate sections, below, describe progress in these three areas. In this second year of an approved five-year program, substantial progress has also been made in PRECP by our coworkers at ANL, BNL, the Air Quality Group at NOAA, and the Department of Meteorology at the $U$ of MD. Progress in these other PRECP components will be reported separately. Many of the studies done to date (especially our field studies) are not scheduled to yield results until future years.

\section{Modeling}

In the first of last year's PRECP annual reports, some general features of our modeling activities were described (Slinn et al. 1986) and three approaches to modeling precipitation scavenging (in terms of scavenging rates, ratios, and efficiencies) were outlined. These three approaches continue to guide our models and measurements. In addition, our modeling activities are organized into the three temporal and spatial scales listed below.

1. The meso-gamma scale (e.g., isolated convective storms or rainbands within frontal storins), characterized by spatial scales typically less than about $20 \mathrm{~km}$ and time scales not more than a few hours. This scale has the feature, especially relevant for atmospheric chemistry modeling, that (except near urban centers) local pollution emissions can generally be ignored compared to the existing burden of airborne pollution (e.g., entering the storm).
2. The meso-beta scale (e.g., entire frontal storms or similar meteorological features), which is characterized by spatial scales out to about $200 \mathrm{~km}$ and a time scale of about 1 day.

3. The meso-alpha scale (e.g., for acidic deposition in the northeastern United States during a multi-day period). For modeling at this 200 to 2,000-km scale, pollution emissions can definitely not be ignored.

Progress is described below in our modeling activities at each of these three scales.

For modeling at the largest (meso-alpha) scale, a cooperative study has been undertaken during FY-86 between personnel working on the PRECP and RADM projects. Under sponsorship of the U.S. Environmental Protection Agency (EPA), the Regional Acidic Deposition Model (RADM) has been developed for NAPAP at NCAR. To start the applications of RADM to help interpret data from PRECP field studies, four case studies have been chosen, one each from the PRECP field studies I through IV. For the numerical simulations, the DOE has provided time on its supercomputer at the Lawrence Livermore Laboratory. During FY-87 the RADM code will be made operational on the DOE computer and at least the first four case studies will be analyzed. In these analyses, RADM will use predictions for the meteorological fields, associated with the four storms, based on numerical solutions of the equations of atmospheric dynamics, driven by initial conditions defined by routine and PRECPmeasured meteorological variables.

A second major set of numerical studies, at both the meso-alpha and -beta scales, was undertaken during FY-86 via PRECP subcontracts to the Universities of Iowa and Kentucky. Currently in these studies, the Sulfur Transport Eulerian Model (STEM) is being used to help interpret the "May-Day Storm" (April 30 to May 2, 1985) sampled during the PRECP-I field study (Busness et a1. 1986). In contrast to RADM, STEM does not generate its own meteorological fields; these are developed by interpolations from routine meteorological measurements. During FY-87, comparisons of the two models with the field data are expected to yield valuable information on how to improve models of acidic deposition. 
For the meso-gamma scale, there have been three major modeling activities. In one, via PRECP subcontract with Carnegie Mellon University, sensitivity and uncertainty analysis techniques are being applied in conjunction with the PLUVIUS model to provide guidance for laboratory and field studies. In the second, via PRECP subcontract with CSU, advanced cloud models are used to supply the meteorological fields needed as input for the PLUVIUS code. In the third, these meteorological fields are used with PLUVIUS to study pollutant processing and removal by convective storms. Illustrative results from the convective-storm modeling are shown in Figures 3 to 5 and Table 1.

\section{Field Studies}

Modeling studies suggest; experiments suggest--and confim or deny. Field studies are therefore the most important component of an atmospheric sciences program, and they account for the majority of PNL's activities in PRECP. During FY-85, we conducted the first two PRECP field studies; during FY-86, two more field campaigns were conducted. In this section, some of the progress in the analyses of the data from PRECP-I through
PRECP-IV will be outlined, as will our preliminary plans for the PRECP $-V$ and PRECP-VI field studies.

As described in last year's annual report, the PRECP field studies are divided into two categories: 1) those without major meteorological support and in which measurements of chemical ratios are emphasized (PRECP-I and -III), and 2) those with major meteorological support (PRECP-II and -IV). For the second category of field studies, we have been fortunate to be able to link our chemistry studies to two national meteorological programs (PRE-STORM and GALE): by linking with these meteorological programs, sufficient meteorological data are available so that we can study not only ratios, but also rates and efficiencies. During $F Y-87$, we expect to conduct the PRECP- $\checkmark$ field studies, emphasizing ratios, and for $F Y-88$, we are working toward linking PRECP-VI to a major meteorological program.

The PRECP-I field studies, described by Busness et al. (1986), were conducted during April 1985. A first draft of the data volume has been published (Tanner et al. 1986). All chemical analyses for ions (airborne and

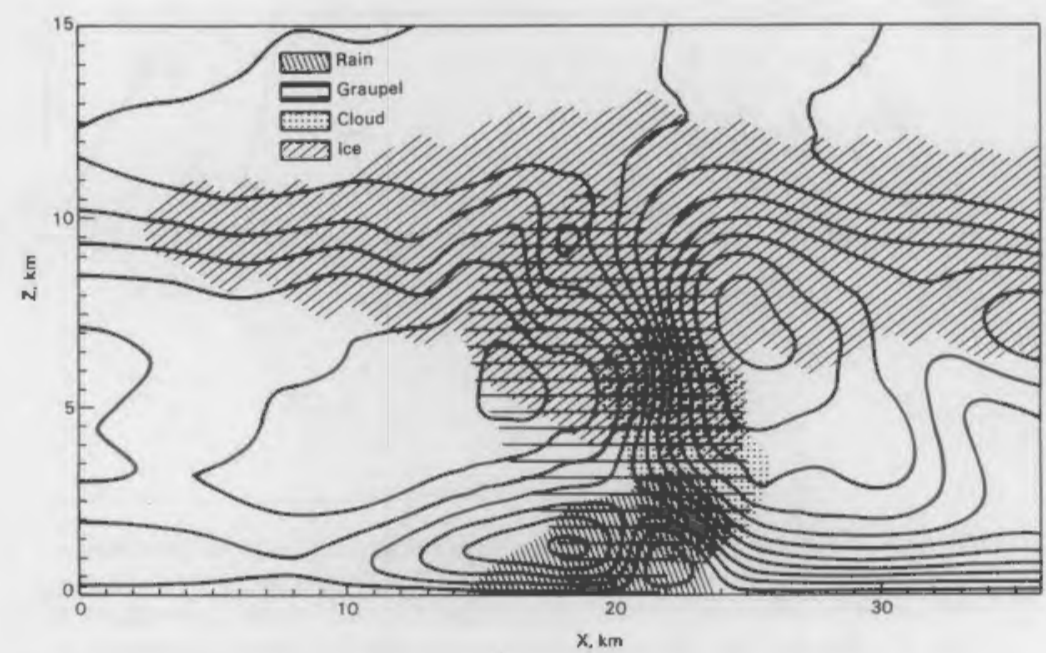

FIGURE 3. Meteorological Fields 47.5 Min into the CSU Cloud-Model Simulation (Tripoli and Cotton 1982, 1986) for a High Plains Thunderstorm (Modeled in Two Dimensions). The striped areas indicate zones where "cloud water" (viz., cloud droplets), rain, graupel, and ice-crystal mixing ratios are above $0.1 \mathrm{~g} / \mathrm{kg}$. The curved solid lines are streamlines. The main inflow region is at the lower right, where the flow is from right to left. The main updraft region is located between $x=20$ and $23 \mathrm{~km}$. From Easter et al. (1987). 


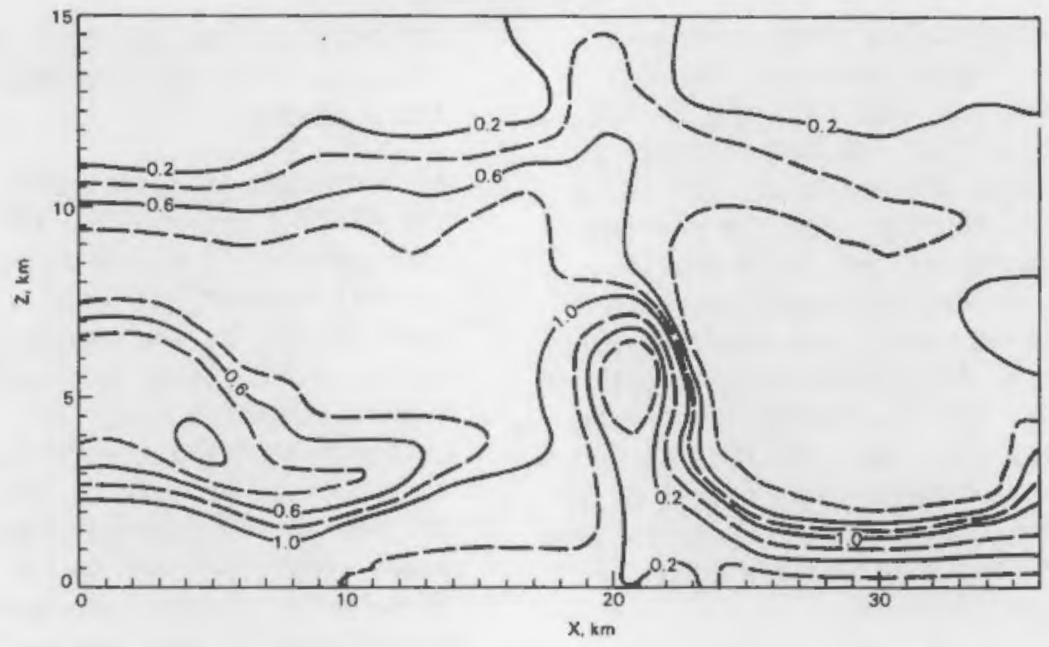

FIGURE 4. Contours of Total Sulfur-IV Mixing Ratio (Sum of Gas and All Waterborne Forms; Equivalent Gas-Phase Concentrations) for the Storm (Assumed to be Steady) Shown in Figure 3. Initial concentrations at the surface, and e-fold scale heights were taken to be: $\mathrm{SO}_{2}, 3 \mathrm{ppb}$ and $2 \mathrm{~km} ; \mathrm{O}_{3}, 50 \mathrm{ppb}$ and constant with height; $\mathrm{SO}_{4}=$ and $\mathrm{NH}_{4}{ }^{+}, 1 \mathrm{ppb}$ and $3 \mathrm{~km}$; and $\mathrm{H}_{2} \mathrm{O}_{2}, 1 \mathrm{ppb}$ and $6 \mathrm{~km}$. From Easter et al. (1987).

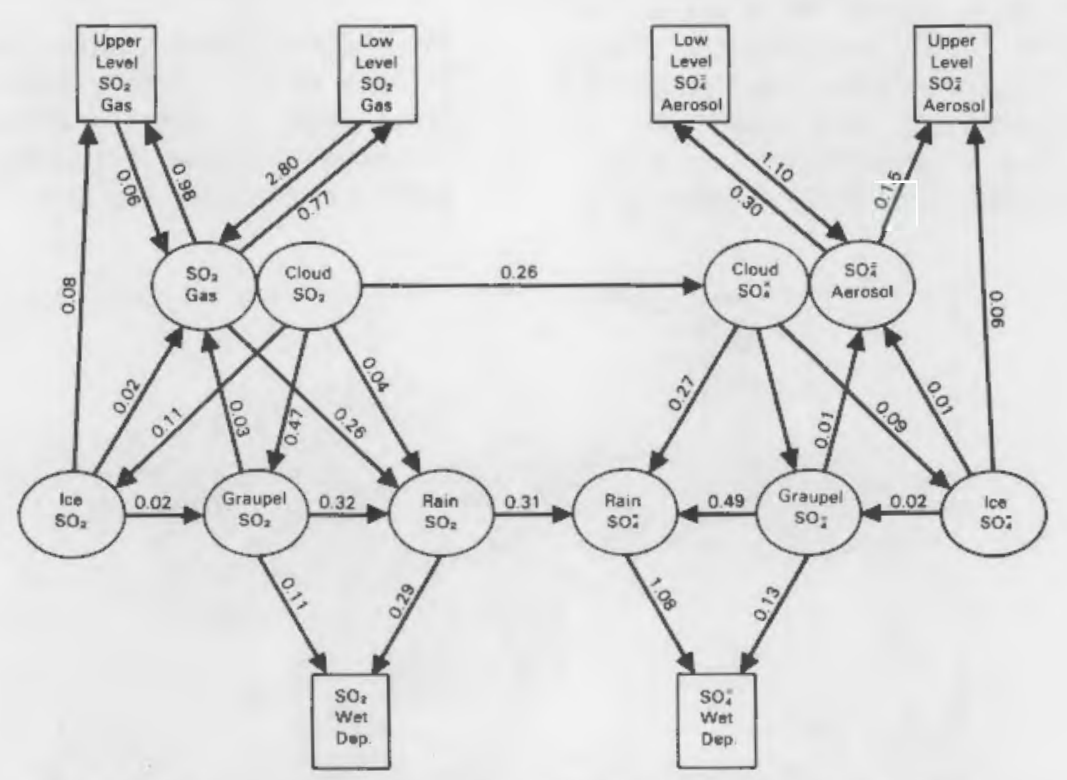

FIGURE 5. Summary of the Processing of Sulfur as Simulated for the Steady Convective Storm Shown in Figure 3. Ellipses identify the distribution of the S-species in the different forms of cloud water ("cloud" = cloud droplets), alt within the cloud. Boxes identify the species outside the control volume, defined to be within horizontal boundaries at 13.75 and $25.75 \mathrm{~km}$ and vertical boundaries at 0 and $11.75 \mathrm{~km}$ (see Figure 3 and Table 1). Arrows between ellipses identify scavenging or chemical-reaction pathways; arrows between ellipses and boxes are inflows or outflows. Adjoining ellipses reflect species assumed to be in chemical equilibrium. Process and flow magnitudes are in control volume $\mathrm{ppb}$ per hour. (One control volume $\mathrm{ppb}$ corresponds to one $\mathrm{pph}$ of the species throughout the entire control volume; rates less than 0.01 are not shown.) From Easter et al. (1987). 
TABLE 1. Summary of inflows and Outflows for the Convective Storm Simulation (Figures 3 through 5). Flow rates are given in control volume ppb per hour (see caption for Figure 5).(a)

\begin{tabular}{|c|c|c|c|}
\hline Species & Flow & Flow Rate & $\begin{array}{l}\text { Percent } \\
\text { of Inflow }\end{array}$ \\
\hline \multirow[t]{2}{*}{ Water } & Inflow & $22,200,000$ & - \\
\hline & Wet Dep. & $9,080,000$ & 41 \\
\hline \multirow[t]{3}{*}{ Sulfate } & Inflow & 1.07 & - \\
\hline & Wet Dep. & 0.67 & 63 \\
\hline & Upper-level Outflow & 0.17 & 16 \\
\hline \multirow[t]{6}{*}{$\mathrm{SO}_{2}$} & Inflow & 2.86 & - \\
\hline & Wet Dep. (as $\mathrm{SO}_{2}$ ) & 0.39 & 14 \\
\hline & Wet Dep. (as $\mathrm{SO}_{4}{ }^{-}$) & 0.54 & 19 \\
\hline & Total Wet Dep. & 0.93 & 33 \\
\hline & Outflow $\mathrm{SO}_{2}$ & 1.06 & 37 \\
\hline & Outflow $\mathrm{SO}_{4}=$ & 0.04 & 01 \\
\hline
\end{tabular}

(a) It is noted that the assumed low pollution concentrations and the calculated large water concentrations result in fairly high $\mathrm{pH}$ values of the rain (4.8 to 5.1) and a fairly large burden of S(IV) in the liquid water, compared to conditions expected in the northeastern U.S. for many storms. Also, the predicted values for the wet-deposited and outflow $\mathrm{SO}_{4}=$ rely directly on an assumed value for the nucleation-scavenging efficiency, taken to be $90 \%$.

rainborne) are completed, as are plots of all continuous-instrument data from the DC-3. Analyses for trace metals have been completed only for precipitation; the aerosol data will be analyzed during the second quarter of FY-87. Numerical analyses with STEM and RADM are under way for some of the campaigns. Calculations of "improved" scavenging ratios (based on aircraft measurements of concentrations in the storm-inflow air) will be performed during $\mathrm{FY}-87$, then chemical data for appropriate network (a) stations are reported, and the results will be submitted for openliterature publication.

The PRECP-II field studies, described by Daly et al. (1986), were conducted during June 1985 in conjunction with the NOAA/NSF PRESTORM program. Analyses of the data are proceeding on schedule:

(a) Appropriate networks include those of the National Atmospheric Deposition Progran (NADP), the Utility Acid Precipitation Sampling Program (UAPSP), and the Multistate Power Production and Pollution Study (MAP3S).
- Storm-scale modeling of a cold-front/ convective-storm system is proceeding via PRECP subcontract with CSU.

- The meteorological data (from the surface and from NOAA's P-3 aircraft) are being processed at NOAA, NCAR, and several universities.

- Improved scavenging ratios and precipitation and scavenging efficiencies are being calculated.

- Figures 6 through 8, from an article published in Science (Dickerson et al. 1987), demonstrate results from one of the prime goals of our studies: to define the concentrations of pollution in the outflow of deep convective storms.

The results shown in Figures 6 through 8 suggest that a significant quantity of atmospheric acids and their precursors are vented, from the lower atmosphere, into the upper

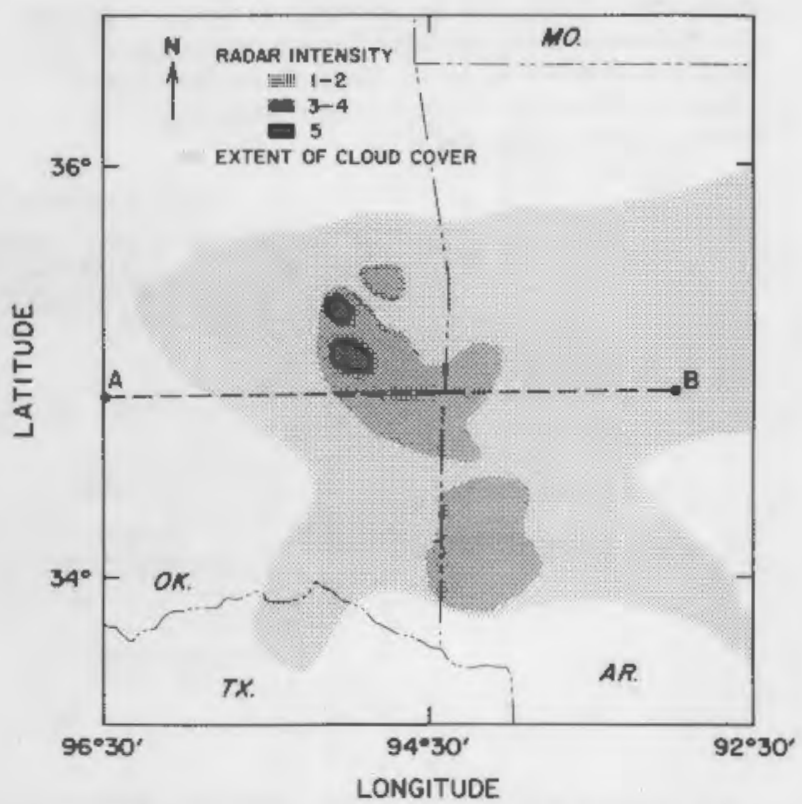

FIGURE 6. Meteorological Analysis of the Research Area for 1000 CST June 15, 1985. A synthesis of the Oklahoma City, Oklahoma and Monett, Missouri radars is superimposed. Level 5 indicates very heavy rain. The outer boundary depicts the horizontal extent of the clood as indicated by satellite infrared images. Line A-B represents the approximate flight track of the research aircraft, and depicts the vertical plane along which the thunderstorm was sectioned to produce Figore 7. From Dickerson et al. (1987). 


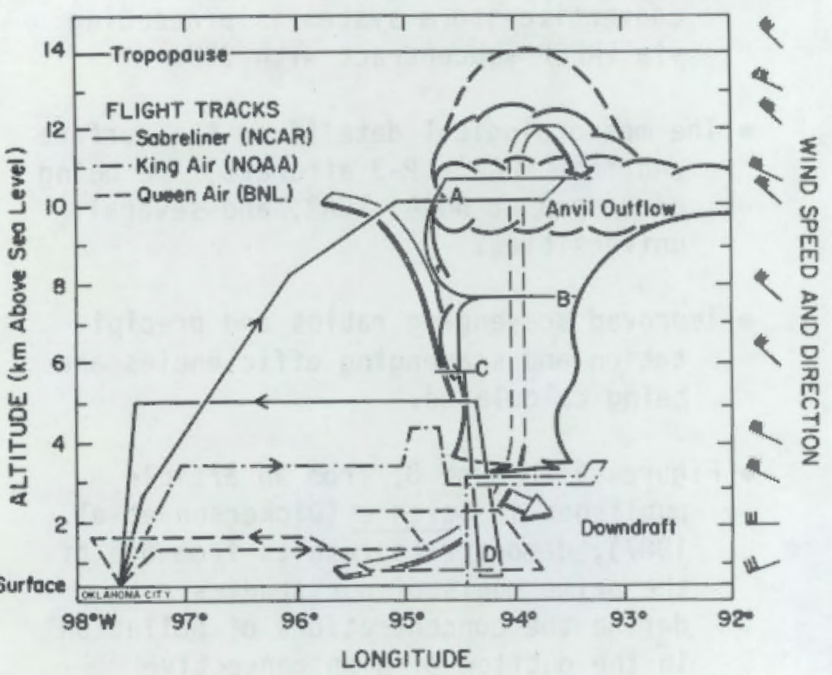

FIGURE 7a. Conceptual Schematic Drawing Based on Balloon Soundings, Radar, Satellite, and In-situ Observations. The dotted line indicates the altitude of the cloud in its mature stage, two hours before the aircraft were in the area. The outflow was toward the SE, to the right and out of the plane of the page. The arrows show the deduced air motions including the inflow and upward transport of moist, polluted boundary-layer air, and the downdraft of cold, upper-tropospheric air. The flight tracks indicate altitude and longitude of the three aircraft. Each whole feather on the wind arrows represents $5 \mathrm{~m} / \mathrm{s}$; a flag represents $25 \mathrm{~m} / \mathrm{s}$. From Dickerson et al. (1987).

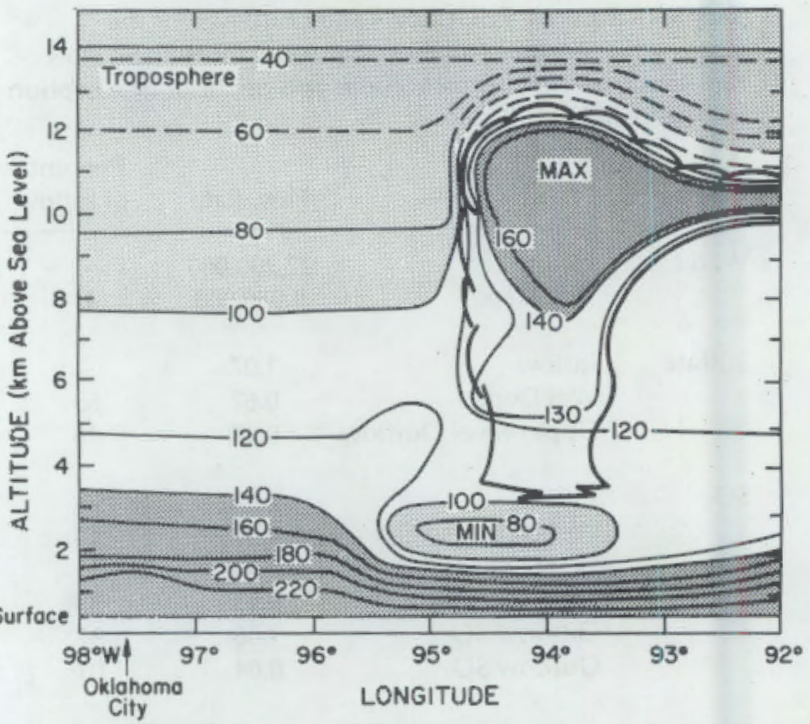

FIGURE Tb. Contour Plot of CO Concentration in ppb. The response time of the instrument is $\sim 60 \mathrm{~s}$. The heavy line shows the location of the cumulonimbus. Dark shading indicates high $\mathrm{CO}$ and light shading indicates low $\mathrm{CO}$. The dashed contour lines are plotted according to climatology (U.S. Standard Atmosphere); no direct measurements were made in that area. From Dickerson et al. (1987).

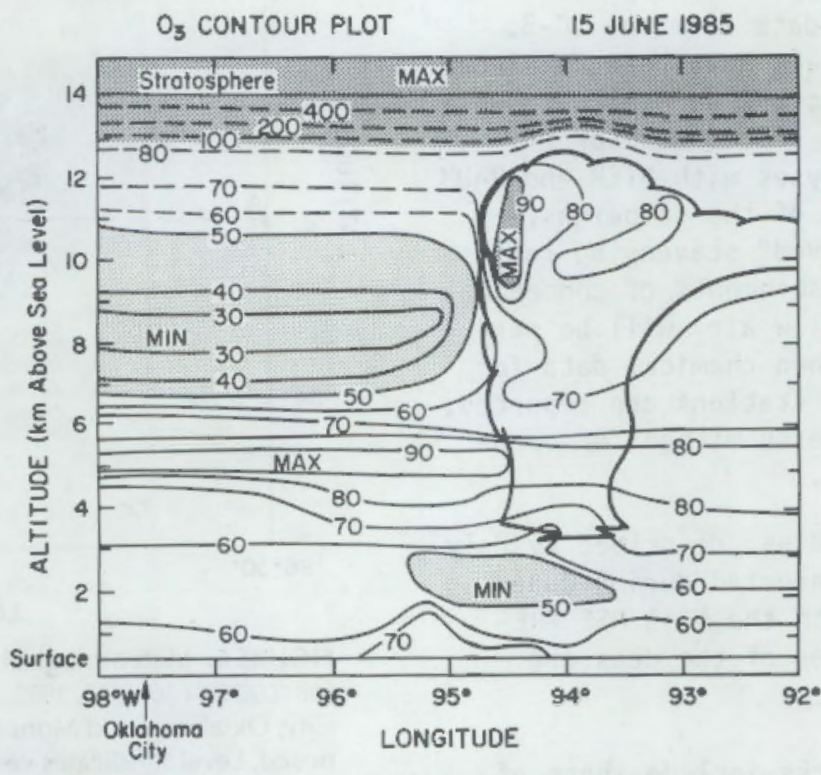

FIGURE 7c. Contour Plot of Ozone in ppb; Data Were Filtered at $60 \mathrm{~s}$. From Dickerson et al. (1987). 


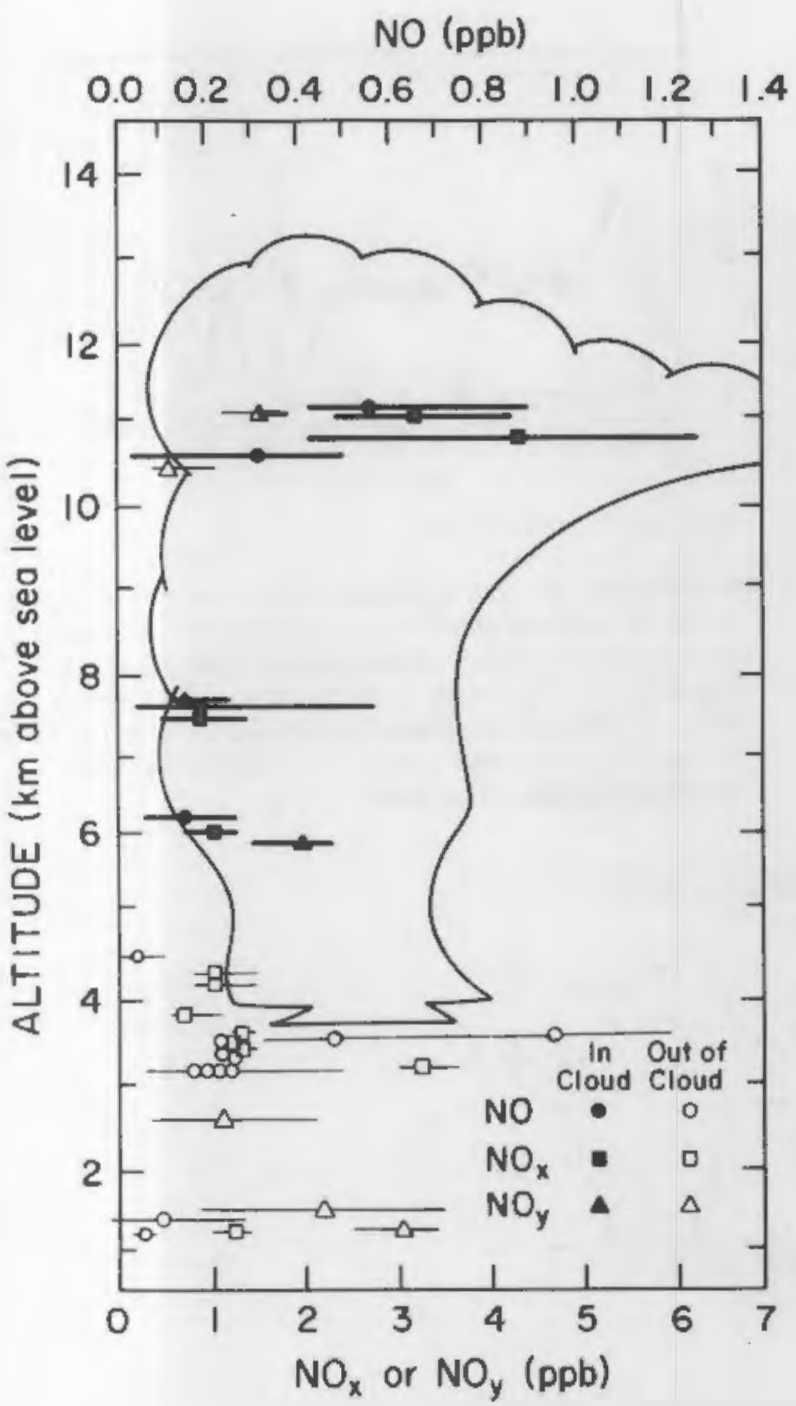

FIGURE 8. Reactive Nitrogen Compounds Measured in and Around the Dissipating Thunderstorm. The circles, squares, and triangles refer to the concentrations of $\mathrm{NO}, \mathrm{NO}_{x}$, and $\mathrm{NO} y$, respectively; note the different scale for $N O$. NO $\mathrm{N}_{\mathrm{x}}$ is defined here as the sum of $\mathrm{NO}, \mathrm{NO}_{2}$ and $\mathrm{PAN} ; \mathrm{NO}_{y}$ is the sum of $\mathrm{NO}_{\mathbf{x}}, \mathrm{HNO}_{3}, \mathrm{HO}_{2} \mathrm{NO}_{2}, \mathrm{~N}_{2} \mathrm{O}_{5}$, and $\mathrm{NO}_{3}$. Filled symbols show measurements made in the cloud; the half-filled symbol shows a measurement made in the transition region as the aircraft exited the cloud. Bars represent the total range. The instrument output was filtered at $10 \mathrm{~s}$ and the sampling time for each point was $\sim 150 \mathrm{~s}$. Some points are displaced slightly in the vertical for clarity. From Dickerson et al. (1987).

troposphere by deep storms. As is described more fully by Dickerson et al. (and see the next section of the present article), this venting can be significant to the modeling of acidic deposition in eastern North America; consequently, expect to extend these type of measurements to include $\mathrm{SO}_{2}, \mathrm{SO}_{4}=$, and trace metals and perform them in the region of the Ohio River valley during PRECP-V and $-V I$.

During FY-86, we performed PRECP-III and -IV, and descriptions of these field studies are given in this volume by Lindsey et al. and Leslie et al., respectively. Figures 9 through 11 show just three additional examples of the many important results available from these studies. Figure 9 shows lowerlevel air, tagged by its $\mathrm{CO}$ concentration (and $\mathrm{SO}_{2}$ and $\mathrm{NO}_{x}$, but these are not shown here) lifted aloft by a pair of cold fronts; Figure 10 indicates the data base from wich we can demonstrate that NO and $\mathrm{NO}_{\mathrm{X}}$ are essentially unaffected by the presence of cloud water (a result predicted from laboratory studies); and Figure 11 indicates the data base for evaluating the influence of clouds on ultraviolet radiation (important for models of photochemistry within clouds). During FY-87 and -88 , the data analyses from these studies will continue, including numerical modeling at the meso-alpha through -gama scales.

\section{Applications}

It is not simple to describe in a few paragraphs the results from PRECP modeling and

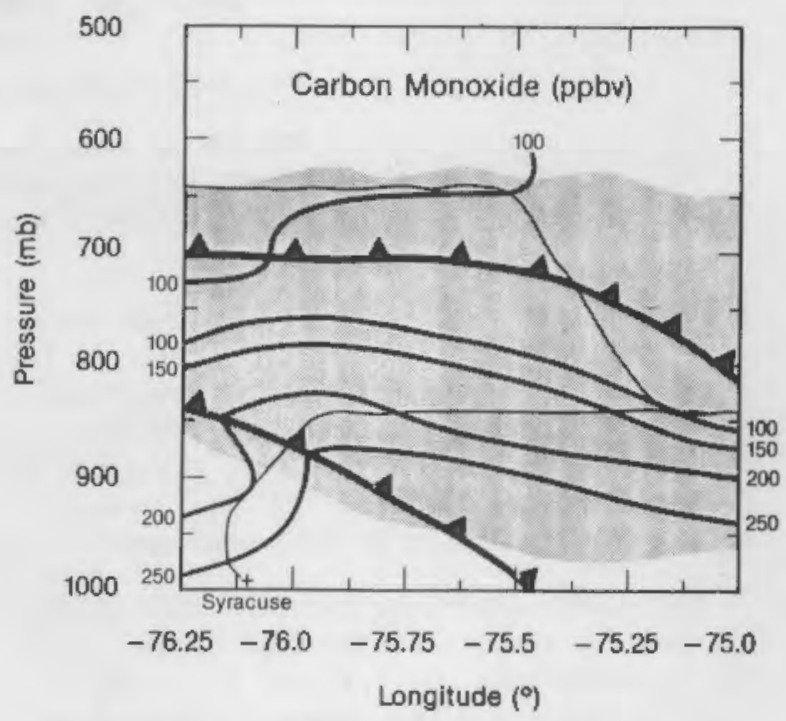

FIGURE 9. Similar to Figure $7 \mathrm{~b}$, These Data Show LowerLevel Air, Tagged by Its CO Content (and $\mathrm{SO}_{2}, \mathrm{NO}$, and $\mathrm{NO}_{\mathrm{x}}$, Though These Data are Not Shown), Vented Aloft by Two Active Cold Fronts, January 22, 1986, near Syracuse, New York. 


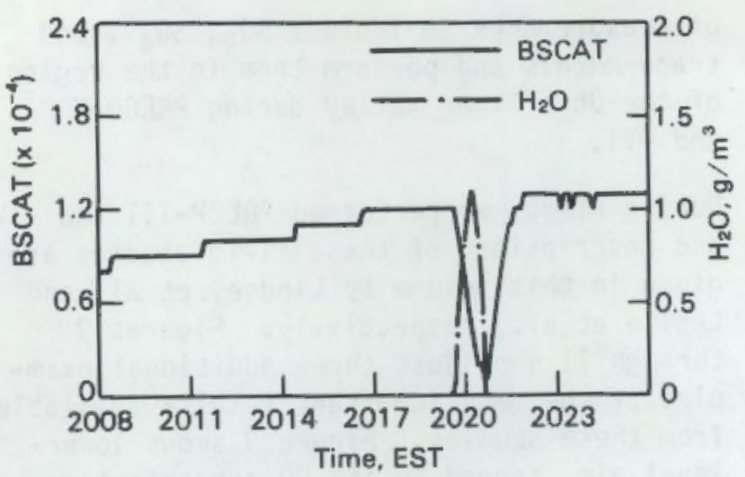

- February 22, $1986(3 \mathrm{~K} \mathrm{ft})$

FIGURE 10a. Illustration of the Correlation Between Responses of Nephelometer ( $b_{\text {scat }}$ ) and Liquid-Water-Content Instruments on the DC-3. This result is useful for identifying the cloud water in Figures $10 \mathrm{~b}$ and $10 \mathrm{c}$.

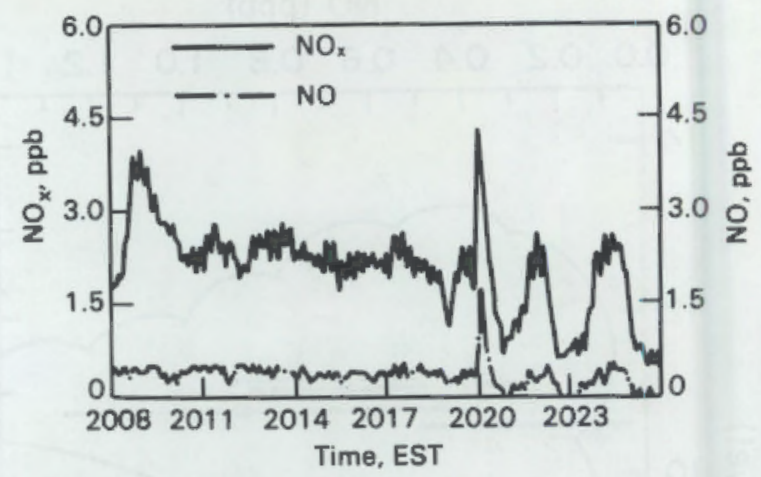

February 22, 1986 (3K ft)

FIGURE 10b. NO and $\mathrm{NO}_{\mathrm{X}}$ Concentrations Corresponding to Figure 10a. Note that the concentrations of these gases are enhanced (at 2020 local time) where the liquid-water concentration (Figure 10a) is at a maximum, assumed to reflect an updraft from the more polluted lower layers, with $\mathrm{NO}$ and $\mathrm{NO}_{\mathrm{x}}$ air concentrations not significantly diminished by the presence of water.

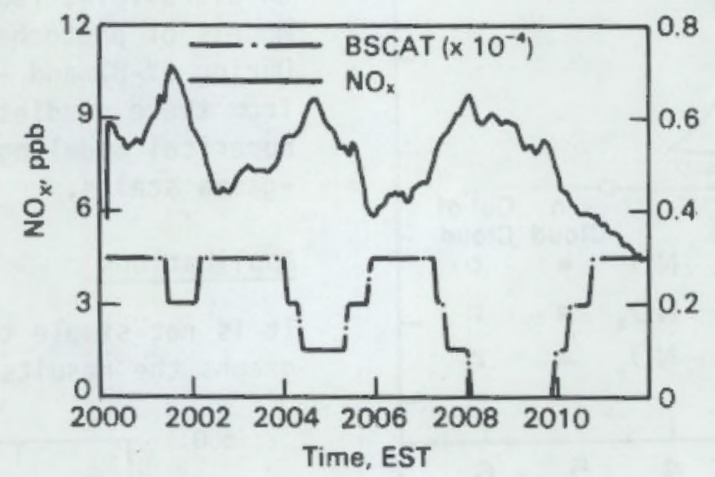

February 21, $1986(6 \mathrm{~K} \mathrm{ft})$

FIGURE 10c. A Dramatic Illustration of the Correlation Between Cloud Water (as Reflected by b $_{\text {scat }}$ see Figure 10a) and $\mathrm{NO}_{\mathrm{X}}$ Within Clouds at $6,000 \mathrm{ft}$.

measurement activities, and it is even more difficult to describe briefiy our efforts to translate the scientific results into forms convenient for the many user comrnunities. [A 100-plus page summary of this translation has been written by Slinn (1987)]. Here, only a few highlights will be mentioned.

To appreciate the climatological significance of specific results (found from either modeling or measurement activities) it is important to understand the chemical climatology of acidic deposition. During FY-86, a statistical analysis of the MAP3S data base waS performed to determine the distribution of wet deposition of specific species over an ensemble of precipitation events. For exampie, Figure 12 shows that approximately $20 \%$ of the precipitation events (at any station in the MAP3S network) account for about $40 \%$ of the annual precipitation and $55 \%$ of the sulfur wet deposition; similar results are found for the other major ions. Figure 13 shows that the single storm that deposits most $\mathrm{SO}_{4}=$ and/or $\mathrm{NO}_{3}{ }^{-}$can occur during any season (though, as seen in Figure 13, sumer months are favored), and such a storm typically deposits about $10 \%$ of the year's total (though a single storm can deposit nearly $30 \%$ of the annual $\mathrm{SO}_{4}{ }^{=}$). 


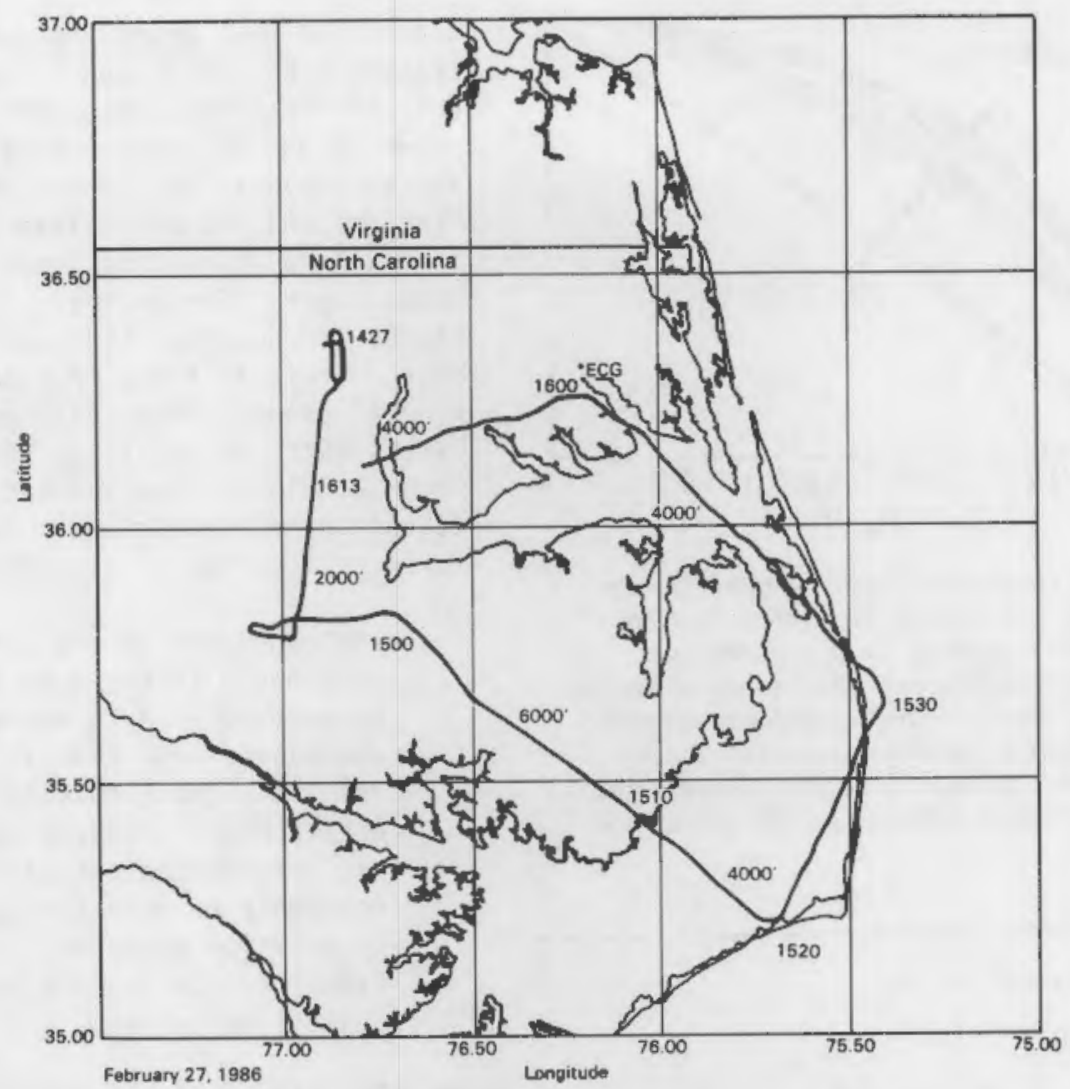

FIGURE 11a. Flight Path and Altitudes, Around Cape Hatteras, for Data Shown in Figure $11 b$.

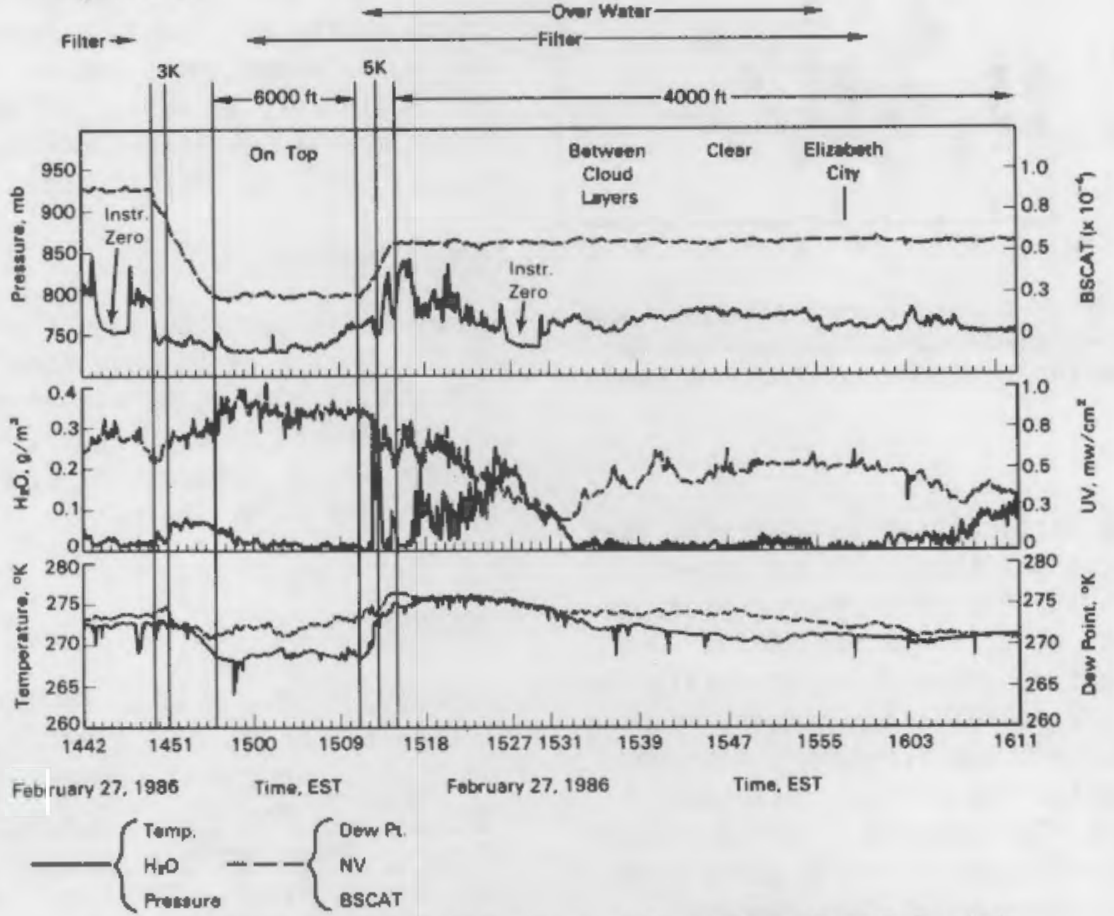

FIGURE 11b. Indication of the Influence of Cloud Cover (Also Defined via Doppler Radars at Cape Hatteras) on Ultraviolet Radiation, for Flight Shown in Figure 11a. Other data, taken on flight spirals within liquid-water clouds and within ice clouds, will be analyzed during FY-87. 


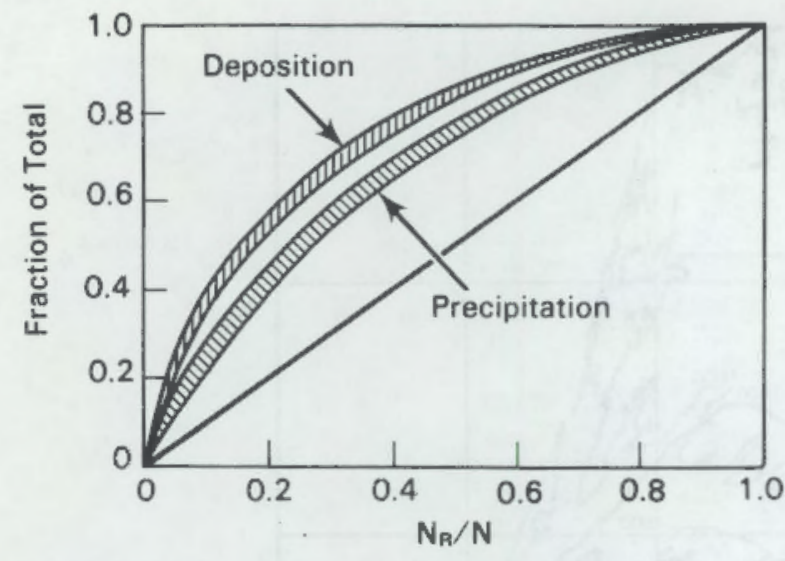

FIGURE 12. Sulfur Deposition and Precipitation Distributions, as Cumulative Totals Versus Deposition-Rank Fraction. Abscissa is rank number of the deposition (rank number of 1 being the highest deposition event) divided by the total number of events; the highest deposition event is therefore at the left. The shading represents the range (mean plus and minus one standard deviation) over eight MAP3S sites for the period 1979 through 1983. From Dana and Slinn (1987).

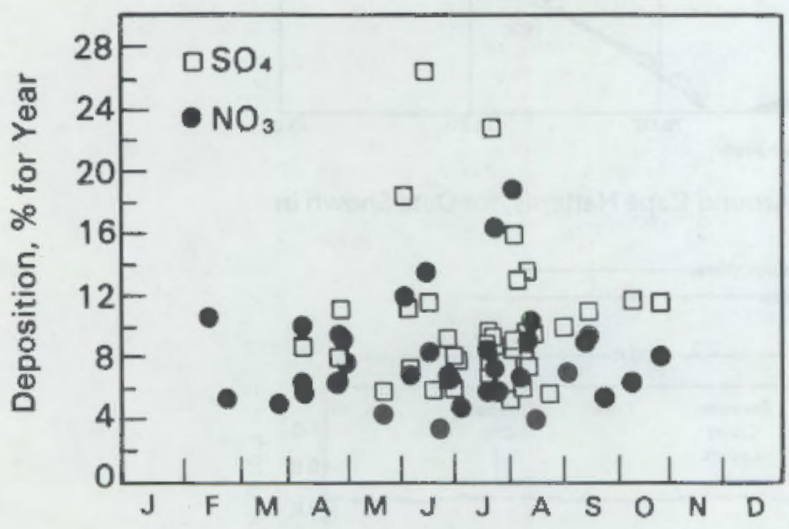

FIGURE 13. Time of Year Versus Fraction of Year's Deposition for the Year's Highest Sulfur and Nitrate Events, for Eight MAP3S Sites During 1979 Through 1983. From Dana and Slinn (1987).

There are many difficulties in assessing the climatological significance of our experimental results for the venting of pollutants by deep storms (e.g., see Slinn 1987). One of the complications, found experimentally by Pickering et al. (1986) under partial funding from PRECP, is that not all deep storms have their roots in the (generally) polluted boundary layer. As examples, Figures $14 \mathrm{a}$ and 14b show concentrations of trace gases within and in the neighborhood of deep cumulus clouds two days after the case study illustrated in Figure 7 , and in contrast to the June 15 PRE-STORM case, this June 17 case shows $\mathrm{CO}$ and $\mathrm{NO}_{\mathrm{Y}}$ concentrations aloft that are noticeably less than mixed-layer concentrations and not significantly different from values at heights immediately above the mixed layer. The analysis associated with Figure $14 \mathrm{c}$ suggests the cause of the difference: the cold front that stimulated the June 17 clouds effectively prevented the direct entry of undiluted boundary-layer air into the clouds, and instead, forced the clouds to have their roots above the mixed layer. Pickering et al. concluded:

The magnitude of the vertical transport noted in the June 15 case cannot be extrapolated to every large convective cell that forms. The results suggest that an accurate estimate will require good statistical information not only on the frequency of deep convection relative to emission patterns, but also on the types of flow regimes associated with convective cells.

Finally, Figure 15 schematically shows a first estimate of the fate of anthropogenic sulfur and nitrogen released to the atmosphere of the northeastern United States, during rain and snow seasons. From future PRECP studies, we expect to be able to provide improved estimates of the numerical values shown in this figure.

\section{Acknowledgments}

Substantial contributions to PRECP progress at PNL during FY-86 have come from D. S. Daly, W. E. Davis, G. W. Dennis, G. L. Laws, D. W. Glover, J. L. Gregory, R. V. Hannigan, R. N. Lee, D. Luecken, D. C. Powe 11, D. S. Sharp, and J. M. Thorp.

\section{REFERENCES}

Busness, K. M., et al. 1986. "PNL's Contribution to the PRECP-I (APRIL) Field Studies." In Pacific Northwest Laboratory Annual Report for 1985 to the DOE Office of Energy Research, Part 3, Atmospheric Sciences. PNL-5750 PT3, pp. 44-54, Pacific Northwest Laboratory, Richland, Washington. 


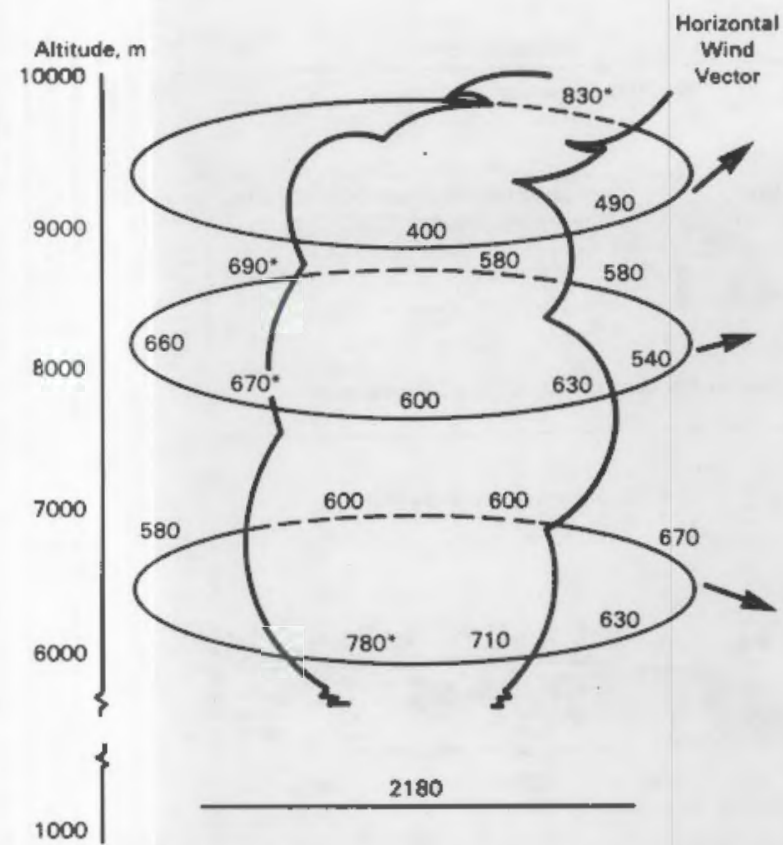

FIGURE 14a. One-Minute average $\mathrm{NO}_{y}$ Concentrations (ppt) Shown on a Schematic Diagram of the Cloud Sampled on June 17, 1985 by NCAR's Sabre-liner and NOAA's King Air. Boundary layer $\mathrm{NO}_{y}$ concentrations are shown at the base of the figure; concentrations within the cloud are indicated with a *. From Pickering et al. (1986).

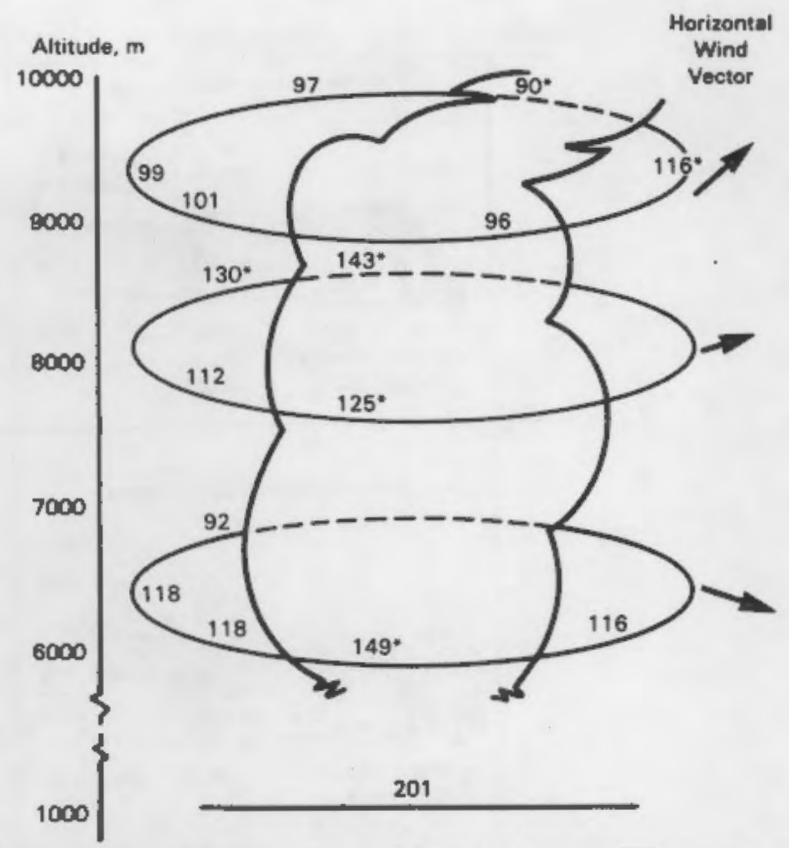

FIGURE 14b. Same as Figure 14a Except for CO in ppb. From Pickering et al. (1986).

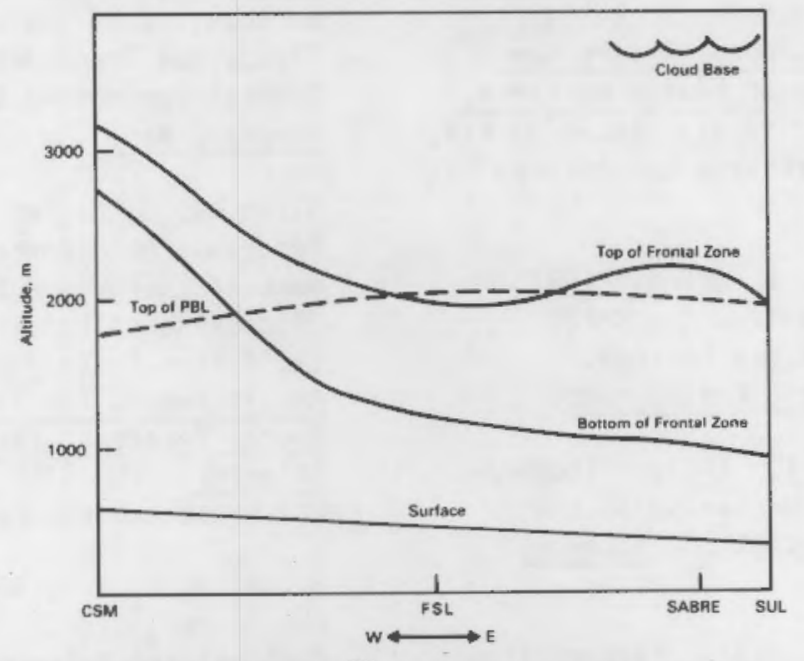

FIGURE 14c. Relationship of Frontal Zone and Top of Boundary Layer on June 17, 1985 as Deduced from Rawinsonde and Sabreliner Data. From Pickering et al. (1986). 


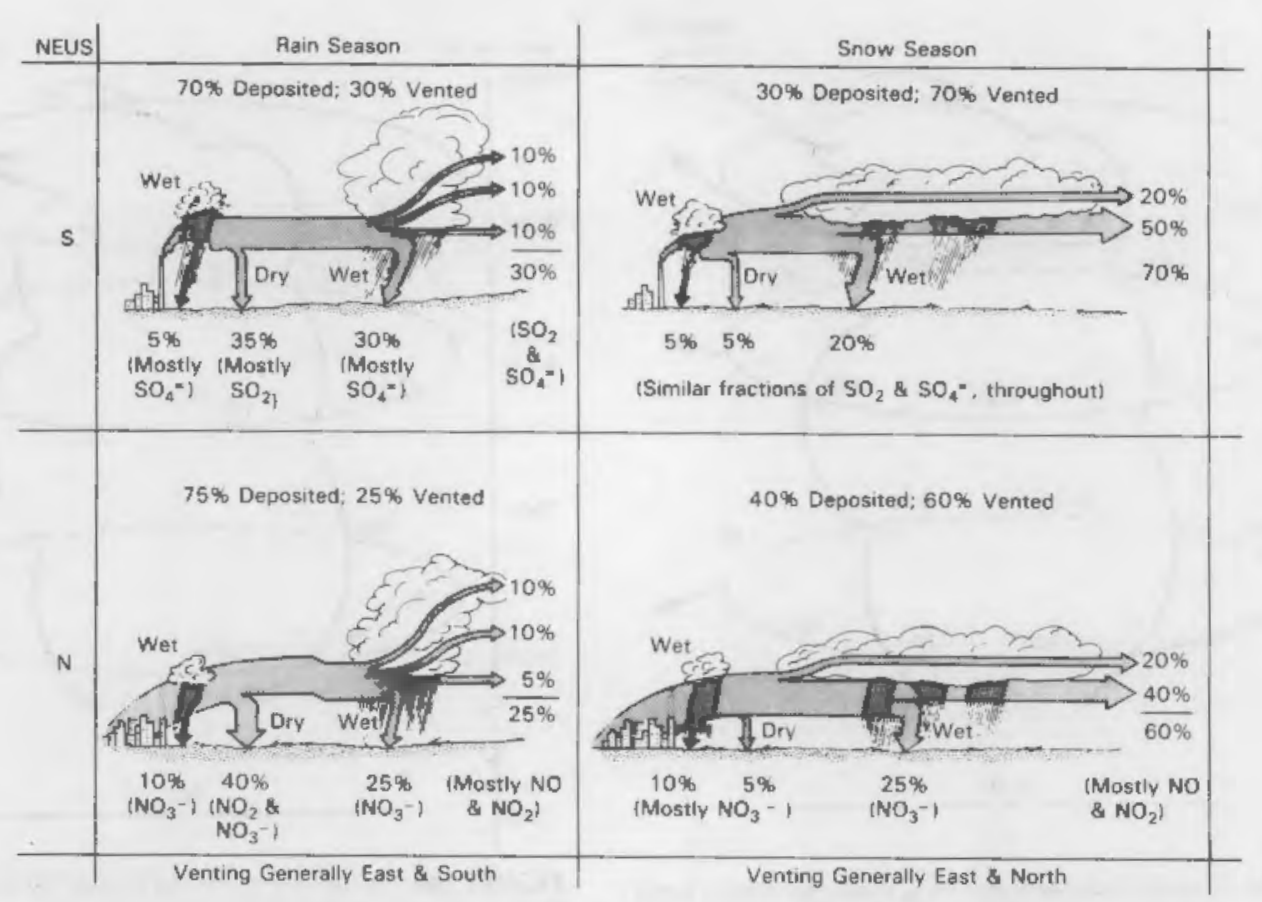

FIGURE 15. Qualitative Estimates for the Atmospheric $S$ and N Budgets in the Northeastern U.S. (NEUS) During Rain and Snow Seasons. From Slinn (1987).

Daly, D. S., et al. 1986. "PNL's Contribution to PRECP-II (PRE-STORM)." In Pacific Northwest Laboratory Annual Report for 1985 to the DOE Office of Energy Research, Part 3, Atmospheric Sciences. PNL-5750 PT3, Pp. 54-64, Pacific Northwest Laboratory, Richland, Washington.

Dana, M. T., and W. G. N. Slinn. 1987. "Deposition Statistics from the MAP3S Network: Episodes and Dry Periods." Submitted to Atmospheric Environment.

Dickerson, R. R., et al. 1987. "Thunderstorms: An Important Mechanism in the Transport of Air Pollutants." Science, 235: 460-465.

Easter, R. C., et al., 1987. "Numerical Simulations of Pollutant Removal and Redistribution by Convective Storms." To be submitted for publication.

Oppenheimer, M. 1984. "The Relationship of Sulfur Emissions to Sulfate in PrecipitationIII. Subregional Budget Analysis." Atmos. Environ. 18(2): 403-408.
Pickering, K. E., R. R. Dickerson, G. J. Huffman, J. F. Boatman and A. Schanot. 1986. "Trace Gas Transport in the Vicinity of Frontal Convective Clouds." Submitted to $\mathrm{J}$. Geophys. Res.

Slinn, W. G. N., et al. 1986. "The PRECP Program--PNL's Contributions to the Department of Energy's Multilaboratory Study of the PRocessing of Emissions by Clouds and Precipitation." In Pacific Northwest Laboratory Annual Report for 1985 to the DOE Office of Energy Research, Part 3, Atmospheric Sciences. PNL-5750 PT3, pp. 37-44, Pacific Northwest Laboratory, Richland, Washington.

Slinn, W. G. N. 1987. "Deposition of Atmospheric Pollution." To be published in Chemical and Meteoralogical Aspects of Atmospheric Source-Receptor Relationships. American Meteorological Society, Baston, Massachusetts.

Tanner, R. L., et al. 1986. PRECP-I Data Volume. BNL-38776, PRECP-85-1, Brookhaven National Laboratory, Upton, New York. 
Tripoli, G. J., and W. R. Cotton. 1982. "The Colorado State University ThreeDimensional Cloud/Mesoscale Model - 1982. Part I: General Theoretical Framework and Sensitivity Experiments." J. Rech. Atmos. $16: 185-219$.

Tripoli, G. J., and W. R. Cotton. 1986. "An Intense, Quasi-Steady Thunderstorm Over Mountainous Terrain. Part IV: Three-Dimensional Numerical Simulation." J. Atmos. Sci. 43:894-912.

PNL'S CONTRIBUTION TO THE PRECP-III (SYRACUSE) FIELD STUDIES

C. G. Lindsey, K. M. Busness, H. E. Davis, D. J. Luecken, J. M. Thorp, W. G. N. Slinn

This article summarizes PNL's contributions to the PRECP-III (Syracuse) field studies conducted during January and February, 1986, in upstate New York. PRECP-III was a cooperative effort involving staff from ANL, BNL, PNL, NOAA/Envi ronmental Research Laboratories, and several universities. In addition to the experiments conducted to address the specific questions posed for the Syracuse studies, several missions were performed in cooperation with the Genesis of Atlantic Lows Experiment (GALE) (see the accompanying article by Leslie et al., wich describes PRECP's role in GALE). ANL's efforts during PRECP-III were led by D. Sisterson, while P. Daum directed BNL's research team. G. Slinn coordinated PNL's activities during PRECP-III, and J. Boatman headed NOAA's contributions to the field studies. This article describes the scientific goals established for the Syracuse experiments and discusses the strategy that was designed to satisfy those objectives. Mission summaries are presented along with some preliminary results from one experiment to demonstrate how completely the goals of PRECP-III were satisfied.

\section{Scientific Objectives}

The emphasis of PRECP-III was to investigate precipitation scavenging of air pollutants by winter storins. Prior to this set of experiments, only limited data have been available to the research community to compare frozenversus liquid-water scavenging processes in cloud and precipitation systems. Researchers have been uncertain, for example, of the relative differences in $\mathrm{SO}_{2}$ or $\mathrm{HNO}_{3}$ uptake by ice versus liquid water; oxidation processes attributable to $\mathrm{H}_{2} \mathrm{O}_{2}$ under freezing conditions; or the capture efficiency of $\mathrm{SO}_{4}=$ particles by ice crystals, to name only a few areas that require more complete information. Thus, the PRECP-III team developed an ambitious set of scientific questions to investigate these and other issues during the field studies.

With this emphasis on winter storm processes, the scientific questions that were posed for the Syracuse experiments both resembled and evolved from the questions addressed during the two previous field programs undertaken by the PRECP program; PRECP-I (April) (Busness et al. 1986) and PRECP-II (PRE-STORM) (Daly et al. 1986). The questions posed for PRECP-1II included:

- What pollutants are entering the inflow zones of winter storms; what are their vertical distributions; how do concentrations in the inflow of $N, S$, and oxidant compounds compare to those found in the inflow to storms that occur during the warm seasons?

- How do winter storms process these inflows; what differences are detectable relative to spring/sumner storm systems; what are the concentrations of pollutants in cloud ice and snow, and how do these concentrations compare to those found in liquid water?

- Relative to the inflow, what are the concentrations in the outflow of winter storms; how do venting processes in the winter differ from those in the summer; does most of the $\mathrm{SO}_{2}$ and $\mathrm{NO}_{x}$ indeed appear in the outflow of winter storms; what are the differences in aerosol concentrations for mixed-phase versus all ice clouds?

- What pollutants are deposited in the precipitation; what spatial and temporal variations are to be found in precipitation scavenging during winter storms; what is the role of $\mathrm{H}_{2} \mathrm{O}_{2}$ versus $\mathrm{SO}_{2}$ versus $\mathrm{SO}_{4}=$ removal rates; does particle scavenging depend on ice-crystal type and structure? 
Table 1 summarizes the prime and subsidiary goals established for PRECP-III, which also were similar to those developed for the earliter PRECP field programs (Slinn et al. 1986). These objectives included documenting the inflow, in-cloud and outflow pollutant concentrations; defining scavenging ratios and inflow-to-outflow concentration ratios for winter snow storms; and comparing

TABLE 1. Prime and Subsidiary Goals for PRECP-III

\section{A. Prime Goals}

1. Document inflow, in-cloud (cloud water and interstitial), and outflow concentrations of pollutants in a "receptor region" during the winter.

2. Obtain scavenging ratios for snow storms (based on inflow air-concentrations) and outflow-to-inflow concentration ratios.

3. Compare relative scavenging rates for different species (by obtaining both sequential samples at the surface and spatial variations via airborne snow collection).

\section{B. Subsidiary Goals}

1. Test airborne snow-chemistry collectors.

2. Test and intercompare different surface-level snow chemistry samplers.

3. Examine the effect of cloud glaciation on pollutants.

4. Examine scavenging and precipitation efficiencies for orographic storms.

5. If meteorological conditions permit, examine the processing of pollutants by lake-effect snow storms.

6. Examine particle removal by individual ice crystals, as a function of crystal habit and electrical charge.

7. Determine if contributions from local emissions (from the Syracuse to Albany lowlands) can be detected within a regional-scale precipitationchemistry signal.

8. Examine the scavenging of elemental carbon and a variety of organic compounds.

9. If meteorological conditions permit, compare scavenging, from the same air mass, by precipitation formed at warm vs. cold fronts.

10. If meteorological conditions permit, examine the contributions to $\mathrm{NO}_{3}$ - deposition from below-cloud scavenging of $\mathrm{HNO}_{3}$. relative scavenging rates for a variety of chemical species. Subsidiary objectives included testing and refining airborne snow collectors; testing and comparing different snow collectors for surface snow sampling; examining scavenging and precipitation efficiencies for orographic and lake-effect storms; and attempting to determine if local emissions can be detected on a regional scale.

\section{Experimenta1 Strategy}

The basic design concept for PRECP-III was to monitor the temporal and spatial distributions of air and precipitation chemistry over a regional-scale area in upstate New York. Three aircraft were used to sample the inflow and outflow air chemistry and to collect cloud water and precipitation samples. A surface observation network was deployed to collect event and sequential precipitation samples and to collect air chemistry and meteorological data.

The following sections describe the study area and summarize aircraft and surface operations.

\section{Study Area}

PRECP-III was conducted in upstate New York between January 6 and February 7, 1986. Figure 1 shows the location of the study area for the Syracuse experiments. The headquarters for directing operations was established at Hancock International Airport in Syracuse (SYR). A secondary operations center was established at Boonville (BNV), New York, approximately 60 miles northeast of Syracuse in the Adirondack Mountains. ANL deployed their mobile air chemistry laboratory at Boonville, and PNL used the Boonville site as the headquarters for processing precipitation samples. Supplemental meteorological data also were collected at the Boonville site. A third manned site was established at Port Ontario, New York, near Lake Ontario, where BNL staff operated their mobile chemistry laboratory.

The Syracuse study area was located in the heart of the New York snow belt, where annual snowfall amounts are greatly enhanced by the presence of Lake Ontario to the north and northwest and the Adirondack Mountains to the northeast. Climatological studies conducted 


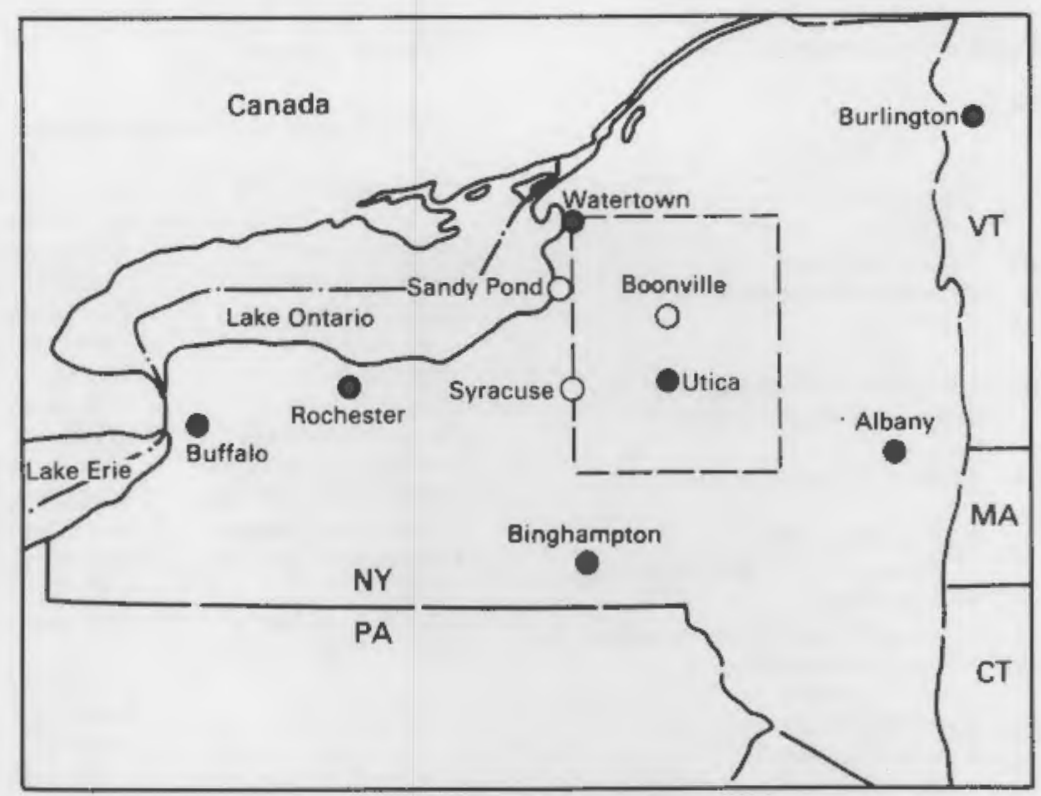

FIGURE 1. PRECP-III Study Area. Surface operation was confined to the boxed area.

prior to the field experiments revealed that, on average, approximately 20 precipitation events per month could be expected in the Syracuse area during January and February. of these events, more than half would not be associated with frontal-type storm systems. Orographic lifting of moist air by the Adirondacks and the influence of lake-effect storms were expected to account for nearly $60 \%$ of the projected snowfall.

The influence of Lake Ontario and the Adirondack harrier produces sharp gradients in annual snowfall amounts in the vicinity of Syracuse. The climatological survey revealed that areas south and west of Syracuse could expect 50 to 80 inches of snow during an average winter. However, only a few miles to the northeast of Syracuse in Adirondack Park, annual snowfall amounts exceeded 180 inches on average. Hence, the local weather conditions were expected to provide ample opportunities to study a variety of winter storm processes.

\section{Aircraft Operations}

The two prime objectives of the aircraft operations component of PRECP-III were:

1. to document below-cloud air, cloud water, and interstitial air composition to better understand physical and chemical processes that determine cloud water composition; and

2. to examine variability in pollutant concentrations in and around clouds to better understand vertical transport in clouds and resulting horizontal inhomogeneities.

The measurements that were needed to accomplish these tasks included below-cloud aerosol and trace gas concentrations and meteorological variables (e.g., temperature, humidity, and winds); cloud-water and interstitial air composition and microphysical properties; and above-cloud air chemistry and meteorological parameters.

Three aircraft were used during the experiments: PNL's DC-3, BNL's Queen Air, and NOAA/ERL's King Air. Table 2 lists the instrumentation capabilities of each aircraft as they were configured for PRECP-III. In addition to the collection of gas and aerosol concentration data (e.g., $\mathrm{CO}, \mathrm{O}_{3}, \mathrm{SO}_{2}, \mathrm{NO}$, $\mathrm{NO}_{x}, \mathrm{HNO}_{3}$, trace metals, and aerosol ions), samplers were deployed to collect cloud water, rainwater, and snow (from which liquid-phase $\mathrm{H}_{2} \mathrm{O}_{2}$ data could be obtained in addition to concentrations of ions and trace metals). 
TABLE 2. PRECP-III Aircraft Instrumentation

a) PNL. DC-3 Instrumentation

\begin{tabular}{|c|c|}
\hline Parameter & Sensor \\
\hline Temperature & $\begin{array}{l}\text { Platinum-Resistance Total Temp. } \\
\text { Sensor }\end{array}$ \\
\hline Dew-point Temperature & Cooled Mirror \\
\hline Pressure & Absolute Pressure Sensor \\
\hline $\begin{array}{l}\text { Cloud Liquid Water } \\
\text { Content }\end{array}$ & Hot Wire \\
\hline Light-scattering (b scat $_{\text {) }}$ & Integrating Nephelometer \\
\hline $\begin{array}{l}\text { Submicron Particles } \\
(0.01 \text { to } 1.0 \mu \mathrm{m})\end{array}$ & Electric Aerosol Analyzer \\
\hline $\begin{array}{l}\text { Small Particles } \\
\quad(0.3 \text { to } 8.0 \mu \mathrm{m})\end{array}$ & Optical Particle Counter \\
\hline $\begin{array}{l}\text { Small Particles } \\
(0.1 \text { to } 3.0 \mu \mathrm{m})\end{array}$ & $\begin{array}{l}\text { PMS ASASP-100X } \\
\text { Aerosol Spectrometer Probe }\end{array}$ \\
\hline $\begin{array}{l}\text { Large Particles } \\
\quad(0.5 \text { to } 47 \mu \mathrm{m})\end{array}$ & $\begin{array}{l}\text { PMS FSSP-100 } \\
\text { Droplet Spectrometer Probe }\end{array}$ \\
\hline $\begin{array}{l}\text { Aerosols/metals/gases } \\
\text { (filter) }\end{array}$ & $\begin{array}{l}\text { Hi-Vol Air Exhauster } \\
\text { with Cyclone }\end{array}$ \\
\hline Hi-Vol Air Flow/Volume & Flowmeter/Totalizer \\
\hline Trace Elements & Cascade Impactor \\
\hline Cloud Water & $\begin{array}{l}\text { ASRC-SUNYA Cloud Water } \\
\text { Collectors }\end{array}$ \\
\hline Precipitation (rain/snow) & $\begin{array}{l}\text { PNL Airborne Precip- } \\
\text { itation Collectors }\end{array}$ \\
\hline $\begin{array}{l}\text { Snow } \\
\mathrm{NO} / \mathrm{NO}_{\mathrm{X}} \\
\mathrm{SO}_{2}\end{array}$ & $\begin{array}{l}\text { PNL Airborne Snow Collector } \\
\text { PNL Chemiluminescent Analyzer } \\
\text { Flame Photometric } \\
\text { Sulfur Analyzer }\end{array}$ \\
\hline $\mathrm{O}_{3}$ & Chemiluminescent Analyzer \\
\hline $\begin{array}{l}\text { Position, Heading, } \\
\text { Airspeed }\end{array}$ & $\begin{array}{l}\text { ONI LORAN-C } \\
\text { Navigation System }\end{array}$ \\
\hline Wind Direction, Velocity & $\begin{array}{l}\text { ONI LORAN-C } \\
\text { Navigation System }\end{array}$ \\
\hline $\begin{array}{l}\text { Data Acquisition } \\
\text { Data Acquisition }\end{array}$ & PMS DAS-64 System \\
\hline Data Acquisition & H-P 9920 System \\
\hline
\end{tabular}

b) NOAA King Air Instrumentation

\begin{tabular}{|c|c|}
\hline Parameter & Sensor \\
\hline Position & LORAN-C \\
\hline$u, v$ & LORAN-C \\
\hline Air Temperature & Platinum Wire \\
\hline Dew Point & Cooled Mirror \\
\hline Pressure & Transducer \\
\hline Cloud Water & Slotted Rod \\
\hline Liquid Water Content & Heated Wire \\
\hline $\begin{array}{l}\text { Drop Concentration } \\
\text { and Distrib. }\end{array}$ & FSSP \\
\hline Aerosol Size Distribution & ASASP-100x \\
\hline $\begin{array}{l}\text { Aerosol Size/ } \\
\text { Composition }\end{array}$ & Filters \\
\hline $\mathrm{SO}_{4}, \mathrm{NO}_{3}, \mathrm{SO}_{2}$ & Filters \\
\hline $\mathrm{CO}$ & U. Denver, Modified \\
\hline $\mathrm{NO}_{x}, \mathrm{NO}_{y}$ & U. Maryland, Modified \\
\hline $\mathrm{SO}_{2}$ & Flame Photometric, Modified \\
\hline
\end{tabular}

Experiments and flight plans were designed for each of the major storm types that were expected during January and February, based on the climatological surveys. Specific operations on a day-by-day basis were selected depending on the prevailing and
TABLE 2. (contd)

c) BNL Queen Air Instrumentation

\begin{tabular}{|c|c|}
\hline Parameter & Sensor \\
\hline $\begin{array}{l}\text { Temperature } \\
\text { Relative Humidity } \\
\text { Static Pressure } \\
\text { True Air Speed } \\
\text { Heading } \\
\text { Position } \\
\text { Horizontal Winds } \\
\text { Scattering Coefficient } \\
\text { Turbulence Intensity } \\
\text { Cloud Liquid Water } \\
\mathrm{NO}_{x}, \mathrm{HNO}_{3}, \mathrm{NO}, \mathrm{NO}_{2} \\
\mathrm{Ozone} \\
\mathrm{SO}_{x}, \mathrm{SO}_{2} \text {, Sulfate } \\
\text { Cloud Water Collection }\end{array}$ & $\begin{array}{l}\text { Thermistor, Reverse Flow } \\
\text { Weather Measure } \\
\text { Transducer } \\
\text { Pitot/transducer } \\
\text { Humphry Gyro } \\
\text { LORAN-C } \\
\text { LORAN-C } \\
\text { Nephelometer } \\
\text { Turbulence Meter } \\
\text { Hot Wire } \\
\text { BNL Modified Monitor Labs } 8840 \\
\text { AID } 560 \\
\text { BNL Modified Melloy } \\
\text { Warm: Standard SUNY CW } \\
\text { Collectors } \\
\text { Supercooled: AES Modified } \\
\text { SUNY Collectors, with } \\
\text { Extractable Meshes }\end{array}$ \\
\hline Rainwater Collection & Standard SUNY Collectors \\
\hline Filter Pack and Flow & BNL Design with CERL \\
\hline $\begin{array}{l}\text { Monitoring System, for } \\
\text { Aerosol Chemical } \\
\text { Composition }\end{array}$ & Separator for Water Extraction \\
\hline $\mathrm{HNO}_{3}, \mathrm{SO}_{2}$ & BNL Filter Pack \\
\hline
\end{tabular}

expected weather conditions (e.g., cold front, warm front, orographic storm, nonprecipitating clouds, etc.). Depending on the objectives defined for a particular mission, the aircraft were either staged together (i.e., simultaneous operations) to produce the best spatial coverage of an event, or staggered so as to provide maximum temporal coverage.

Several instruments were installed or relocated on PNL's DC-3 to better satisfy the mission objectives of PRECP-III. Particle spectrometer probes that had previously been operated from a forward, upper-fuselage position were moved to permit simultaneous use of cloud-water, rain, and snow collectors at that position. After constructing mounts and installing wiring in the wing, the ASASP-100X (aerosol) and FSSP-100 (droplet) probes were mounted beneath the right wing. Precipitation and cloud-water collectors were then operated from the upper fuselage position as they were during the April 1985 PRECP-I study (Busness et al. 1986). The prototype PNL airborne snow collector (Slinn et al. 1986) was operated from this position as well. While this device was somewhat awkward to 
deploy in flight, snow samples were successfully collected. Modifications to the device are planned to improve ease of operation and collection efficiency.

A cyclone separator was installed in the high-volume sampling line so that the highvolume sampling ports for aerosol, gas, and trace metal filter collections could still be used while flying in clouds and precipitation. The cyclone prevented large droplets and precipitation from impacting the filter media. While this system worked well, the anticipated use of the cyclone for rain and snow collection was not so successful.

A new microcomputer-based data acquisition system was used successfully during the Syracuse study. The system acquired data from the real-time chemical and meteorological probes once per second. The data acquisition system continuously obtained aircraft position, speed, heading, wind direction, and wind speed data via a serial interface to the LORAN-C navigation system. All data were recorded on compact tape cartridges and simultaneously displayed on a CRT monitor for in-flight observation. Following a flight, the tapes were read with a similar ground-based system so that the data could be reviewed to ensure correct operation of all instruments.

\section{Surface Operations}

Surface operations included precipitation collection, air chemistry observations, and acquisition of meteorological data. A fixed precipitation collection network was established in the study area, as shown in Figure 2. Collectors were deployed to obtain event snow (or rain) samples at each site. During a mission, members of the research team were sent into the network to collect sequential precipitation samples. These samples have been analyzed for the major ions, $\mathrm{H}_{2} \mathrm{O}_{2}$, and $\mathrm{S}$ (IV); trace-element analyses are not yet completed.

Surface-level air chemistry data were taken at BNL's Port Ontario site, ANL's mobile laboratory at Boonville, and at selected sites in the network (where high-volume air samplers were deployed). Tables 3 and 4 list the measurements acquired by the BNL and ANL mobile laboratories, respectively. Highvolume samplers were installed at the Port

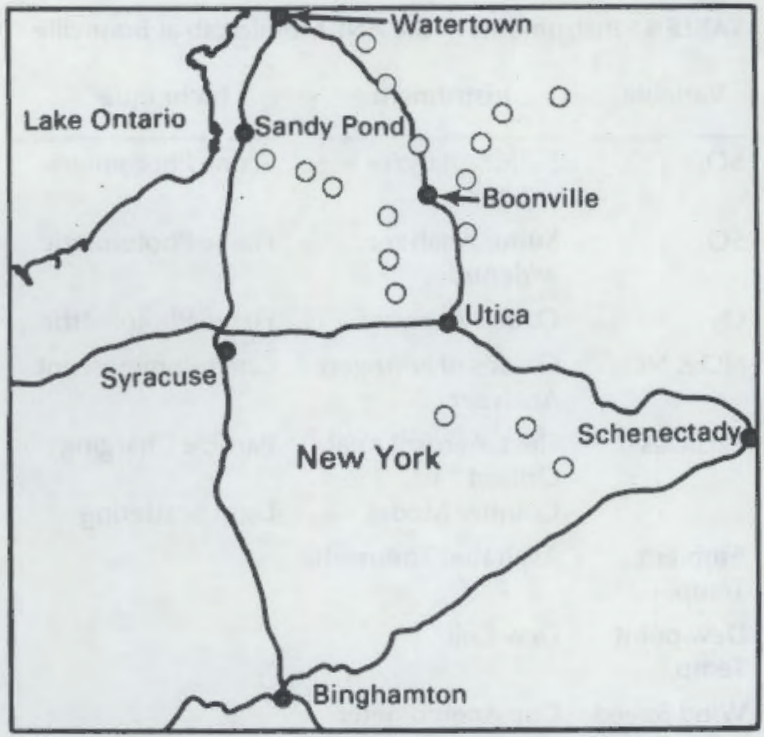

FIGURE 2. The PRECP-III Surface Network. Precipitation collection sites are indicated by open circles.

TABLE 3. BNL Van Instrumentation, Port Ontario

\begin{tabular}{|c|c|c|}
\hline Parameter & Time Resolution & Technique \\
\hline $\mathrm{NO}_{\mathbf{x}}$ & Continuous & $\mathrm{O}_{3}$ Chemiluminescenc \\
\hline $\mathrm{SO}_{2} \hat{n}$ & Continuous & Flame Photometry \\
\hline & Continuous & UV Absorption \\
\hline Aldehyde & 1 hour & Bubbler \\
\hline $\mathrm{H}_{2} \mathrm{O}_{2}$ & Continuous & $\begin{array}{l}\text { Bubbler } \\
\text { PHOPAA }\end{array}$ \\
\hline PAN & $1 / 2$ hour & Gas Chromatograph \\
\hline & 8 hour & Filter Pack (BNL) \\
\hline $\begin{array}{l}\text { Trace Metals } \\
\mathrm{NH}_{3} \\
\text { Particles }\end{array}$ & 8 hour & Filter Pack (PNL) \\
\hline $0.001-1 \mu \mathrm{m}$ & 15 min. avg. & EAA (Whitby) \\
\hline $0.3-10 \mu \mathrm{m}$ & 15 min. avg. & Climet \\
\hline bscat $_{\text {sc }}$ & Continuous & Nephelometer \\
\hline Precip. Rate & Continuous & Belfort Gauge \\
\hline Precip. Chem. & Event & Two Samplers \\
\hline & Sequential (hrly) & Three Samplers \\
\hline Soundings & 14 and $18 \mathrm{Z}$ & ANL Airsonde \\
\hline Temperature & Continuous & Thermocouple \\
\hline RH & Hourly & Wet/dry Bulb \\
\hline
\end{tabular}

Ontario site, at Boonville, and at four other network locations. These samplers were used to determine surface air concentrations of aerosol ions, $\mathrm{HNO}_{3}, \mathrm{SO}_{2}, \mathrm{NH}_{3}$, and trace metals.

Meteorological data acquired during PRECP-III included the routine National Weather Service (NWS) surface and upper-air observations taken in the New York area. The surface data 


\begin{tabular}{|c|c|c|}
\hline Variable & Instrument & Technique \\
\hline $\mathrm{SO}_{2}$ & $\begin{array}{l}\text { Sulfur Analyzer } \\
\text { w/filter }\end{array}$ & Flame Photometric \\
\hline $\mathrm{SO}_{4}$ & $\begin{array}{l}\text { Sulfur Analyzer } \\
\text { w/denuder }\end{array}$ & Flame Photometric \\
\hline $\mathrm{O}_{3}$ & Ozone Analyzer & Flame Photometric \\
\hline $\mathrm{NO} \& \mathrm{NO}_{\mathrm{x}}$ & $\begin{array}{l}\text { Oxides of Nitrogen } \\
\text { Analyzer }\end{array}$ & Chemiluminescent \\
\hline Particles & $\begin{array}{l}\text { Elect. Aerosol Anal. } \\
\text { Optical Part. } \\
\text { Counter Model }\end{array}$ & $\begin{array}{l}\text { Particle Charging } \\
\text { Light Scattering }\end{array}$ \\
\hline $\begin{array}{l}\text { Ambient } \\
\text { Temp. }\end{array}$ & Aspirated Thermistor & \\
\hline $\begin{array}{l}\text { Dew-point } \\
\text { Temp. }\end{array}$ & Dew Cell & \\
\hline $\begin{array}{l}\text { Wind Speed } \\
\& \text { Dir. }\end{array}$ & $\begin{array}{l}\text { Cup Anemometer } \\
\text { and Vane }\end{array}$ & \\
\hline Pressure & Microbarograph & \\
\hline
\end{tabular}

included hourly precipitation rates recorded at a number of stations in New York. Supplemental surface observations and upper-air soundings were collected at Boonville and Port Ontario (PNL operated a rawinsonde station at the Boonville site; BNL used an Airsonde system at Port Ontario to obtain temperature profiles). In addition, the GALE program acquired supplemental upper-air soundings at NWS stations in the Northeast on two occasions during PRECP-III. The Syracuse aperations center archived MWS facsimile charts of surface and upper-level conditions, satellite images, and MS weather radar images. The Hanford Meteorology Station operated by PNL also collected and archived NWS facsimile charts as well as hourly surface airways observations for New York and coded rawinsonde data for the northeastern United States.

\section{Special Studies}

In addition to the major objectives and strategies outlined above, several special studies were conducted as part of PRECP-III to attempt to provide more complete information on snow scavenging. These special studies were conducted at the Boonville and Port Ontario sites. Issues addressed by these studies included: ice crystal characterization; snow scavenging of particles; snow scavenging of organic gases; snow electricity studies; snow scavenging of elemental carbon particles; and an intercomparison of several snow collection procedures and samplers.

One of the special studies that was of particular interest to PRECP researchers was the Snow Chemistry Intercomparison Test (SCIT). The objective of SCIT was to compare collection efficiencies between different snow sampling devices and to determine if any differences could be detected in the chemical composition of snow samples obtained simultaneously by the different collectors. Knowledge of collection efficiencies is extremely important, especially in light snowfalls where the total sample weight collected is near the minimum value necessary for sample analysis.

For most of the storms studied during PRECP-III, nine different snow collectors were deployed at Boonville as part of the SCIT study. The collectors used were:

- CB (IB) - Canadian bag in the standard trash cans used for collection of ion balance samples.

- CB (TM) - Canadian bag in the standard trash cans used for collection of trace metal samples.

- $O B$ - Hanford bags used to sample for trace metals and to compare with the Canadian bags.

- CB SCOOP - Ion balance and trace metal samples scooped off the top layer of snow after a snow event. Used to compare with the event $C B$ samples.

- CB TILT - Ion balance samples taken by the same method as CB (IB), but with the trash can tilted into the snowfall.

- PS - Plastic sheet on plywood basin, large-area collector, used as a backup method for light snow events.

- WS - Warren Springs aerodynamically designed sampler with heated collection surface.

- SM - Standard monitoring automatic opening bucket. 
- FN - ANL-supplied funnel for collection of trace metal samples during rain events.

These samplers were deployed side-by-side at the beginning of a snowfall event. The samples were removed for analysis either at the conclusion of the event, intermittently during the event when a large amount of snowfall occurred, or between events, depending on the storm conditions. Collection of the CB (TM) and (IB) samples were coordinated as much as possible with the Boonville sequential samples so that the integrated concentrations could be compared. A total number of 52 SCIT trace metal samples and a similar number of ion balance samples were collected.

A preliminary estimate of the collection efficiencies of the snow samplers was calculated based on each sampler's collection area and the total weight of snow collected by the sampler. The total amount of snow collected by the CB (TM) method was used to normalize for the total amount of snowfall during the event. The averaged values, using CB (TM) as 1, are as follows:

$$
\begin{array}{ll}
\text { CB (IB) } & =1.17 \pm 0.53 \\
\text { WS } & =0.99 \pm 0.26 \\
\text { SM } & =0.54 \pm 0.24 \\
\text { PS } & =1.51 \pm 1.56
\end{array}
$$

Some of the samplers show a large amount of variation in these preliminary collection efficiencies; factors such as wind speed and direction, total snow loading, etc., may influence the results. During the coming year, the influence of these and other factors will be investigated. The initial results show that the different samplers can display a widely varying range of collection values.

\section{Mission Summaries}

During PRECP-III there were very few 'down' days, because winter storm activity in January and February in upstate New York was vigorous. Research operations began on January 13 and concluded on February 4. Fifteen missions were conducted during this 22-day period. During the first week of the program, rain was the predominant form of precipitation collected by the aircraft and the surface network. For the remainder of the program, most of the storm systems that passed through the area deposited snow, often in very large amounts. Although winter storms can produce hazardous flying conditions, careful planning and execution of operations by the aircraft teams resulted in very few missions cancelled or terminated early because of icing conditions.

Table 5 summarizes the missions that were conducted during the Syracuse field study. Listed are the dates of each mission, the prevailing weather conditions, the aircraft that were used and when they flew, a summary of the types and numbers of precipitation samples collected in the surface network, and a sumary of the types and numbers of integrated samples collected by the aircraft. A variety of meteorological conditions were encountered during the experiments, wich will provide excellent opportunities to compare scavenging processes attributable to, for example: 1) systems producing surface precipitation in the form of rain versus snow; 2) cold fronts versus orographic storms; 3) pre-frontal versus post-frontal air masses; and 4) scavenging by liquid versus frozen cloud water. As indicated in Table 5, aircraft operations frequently continued throughout the daylight hours of a mission day, providing excellent temporal and spatial resolution of precipitating systems. Likewise, numerous precipitation samples were collected in the surface network.

\section{General Summary of the January 22 Mission}

As an example of the conditions studied during PRECP-III, the following section reviews the January 22, 1986 , mission. This case has been selected for further study by the NOAA/ERL team because the data suggested that several different air masses were processed by this storm. A double cold front passed through the network during the day, depositing light precipitation ahead of and behind the frontal systems. The goal for this mission was to document pollutant concentrations in the inflow and outflow zones of the first cold front as well as in the air mass behind the second, arctic front. Airborne and surface precipitation samples would be collected as conditions permitted.

\section{Mission Meteorology}

On January 22, a low pressure center, located over Iowa on the 21st, had moved over the Great Lakes early in the day and continued to 
TABLE 5a. PRECP III, Syracuse, New York, Jan - Feb 1986

\begin{tabular}{|c|c|c|c|c|c|c|c|c|}
\hline Date & Weather Summary & NC Flights & $\begin{array}{l}\text { BNV } \\
\text { RS }\end{array}$ & $\begin{array}{l}5 \\
\varepsilon \\
Q^{(a)}\end{array}$ & $\begin{array}{l}\mathbf{E} \\
V \\
\mathrm{~N} \\
\text { T(a) }\end{array}$ & $\begin{array}{l}\mathbf{F} \\
\underline{P(a)}\end{array}$ & $\begin{array}{l}\mathrm{s} \\
\mathrm{C} \\
\mathrm{i} \\
\mathrm{T(a)} \\
\end{array}$ & Remarks \\
\hline $\begin{array}{l}\text { 1/13/86 } \\
\text { Mon }\end{array}$ & $\begin{array}{l}\text { Light snow. KF } \\
\text { and arctic front. }\end{array}$ & QA, DC-3 & 0 & 0 & 0 & 0 & 0 & $\begin{array}{l}\text { Ground stations not yet activated. Tested } \\
\text { cyclone snow collector on aircraft. }\end{array}$ \\
\hline $\begin{array}{c}1 / 15 / 86 \\
\text { Wed }\end{array}$ & $\begin{array}{l}\text { Scattered cirrus. } \\
\text { Very cold }\end{array}$ & QA & 0 & 0 & $\mathbf{0}$ & 0 & 0 & $\begin{array}{l}\text { No ground sampling on this day. Temp. } \\
-11 F \text { to } 15 F \text {. Clear air flight. Made vertical profiles } \\
\text { over Boonville. }\end{array}$ \\
\hline $\begin{array}{l}\text { 1/17/86 } \\
\text { Fri }\end{array}$ & $\begin{array}{l}\text { Thickening and } \\
\text { lowering ovc. as } \\
\text { WF approaches. } \\
\text { Light rain. }\end{array}$ & KA, DC-3 & 0 & $\begin{array}{l}2 \\
(7)\end{array}$ & $\begin{array}{c}4 \\
(4)\end{array}$ & & $\begin{array}{c}1 \\
\text { (R) }\end{array}$ & $\begin{array}{l}\text { Warmer, } 17 \mathrm{~F} \text { to high } 40 \mathrm{~s} \text {. Calibration and } \\
\text { cloud-water samples by aircraft. }\end{array}$ \\
\hline $\begin{array}{l}1 / 18 / 86 \\
\text { Sat }\end{array}$ & $\begin{array}{l}\text { Clear. Stratus } \\
\text { moved in at sunset. } \\
\text { Low pressure over } \\
\text { Great Lakes. }\end{array}$ & KA & 0 & $\begin{array}{l}4 \\
(0)\end{array}$ & $\begin{array}{c}4 \\
(0)\end{array}$ & & $\begin{array}{c}1 \\
(\mathrm{R})\end{array}$ & $\begin{array}{l}\text { KA characterized the inflow ahead of an } \\
\text { approaching KF. Ground stations got no } \\
\text { precipitation. Event, SCIT, and sequen- } \\
\text { tial samples were left out until afternoon of } 1 / 19 \text {. }\end{array}$ \\
\hline $\begin{array}{l}1 / 19 / 86 \\
\text { Sun }\end{array}$ & $\begin{array}{l}\text { Complex frontal } \\
\text { systems on either } \\
\text { side of Syracuse. } \\
\text { Three low pressure } \\
\text { centers. }\end{array}$ & $\mathrm{QA}, \mathrm{KA}, \mathrm{DC}-3$ & 4 & 1 & $\begin{array}{l}6 \\
(6)\end{array}$ & $\begin{array}{l}4 \\
(12)\end{array}$ & $\begin{array}{l}1 \\
\text { (R) }\end{array}$ & $\begin{array}{l}\text { Intermittent rain from morning to even- } \\
\text { ing. The } 3 \text { aircraft flew relay flights } \\
\text { into the frontal system and around it to } \\
\text { collect cloud and rain water. }\end{array}$ \\
\hline $\begin{array}{c}1 / 20 / 86 \\
\text { Mon }\end{array}$ & $\begin{array}{l}\text { Ovc. Lt. rain } \\
\text { occnly moderate. } \\
\text { Rain to snow at } \\
1600 .\end{array}$ & $\mathrm{QA}, \mathrm{KA}, \mathrm{DC}-3$ & 3 & $\begin{array}{l}5 \\
(37)\end{array}$ & $\begin{array}{l}6 \\
(12)\end{array}$ & $\begin{array}{l}3 \\
(5)\end{array}$ & $\begin{array}{l}1 \\
\text { (S) }\end{array}$ & $\begin{array}{l}\text { The } 3 \text { aircraft flew circular patterns } \\
\text { in clouds and rain around a slow moving } \\
\text { surface and } 850 \text {-mb low near Binghampton, } \\
\text { New York. Mild in morning ( } 45 F \text { ). 30F in afternoon. } \\
\text { SCIT left out until } 1130 \text { on } 1 / 21 \text {. }\end{array}$ \\
\hline $\begin{array}{c}1 / 22 / 86 \\
\text { Wed }\end{array}$ & $\begin{array}{l}\text { Lowering and } \\
\text { thickening ove. } \\
\text { KF at Syracuse } \\
\text { near noon. } \\
\text { Arctic front later. }\end{array}$ & QA, KA, DC-3 & 2 & $\begin{array}{c}1 \\
\text { (3) }\end{array}$ & $\begin{array}{l}10 \\
(11)\end{array}$ & $\begin{array}{l}4 \\
\text { (9) }\end{array}$ & $\begin{array}{l}2 \\
(R, S)\end{array}$ & $\begin{array}{l}\text { Spotty rain and sprinkles. Most precip. } \\
\text { at Boonville and Sandy Pond. Aircraft } \\
\text { characterized air ahead of KF. Event } \\
\text { samples, most of the sequential samples } \\
\text { and } \$ 2 \text { SCIT were left out until } 1 / 23 \text {. }\end{array}$ \\
\hline $\begin{array}{l}1 / 25 / 86 \\
\text { Sat }\end{array}$ & $\begin{array}{l}\text { Ovc. Snow at } \\
\text { Boonville in a.m., } \\
\text { at Syracuse in p.m. }\end{array}$ & $Q A, K A$ & 4 & $\begin{array}{l}5 \\
(23)\end{array}$ & $\begin{array}{l}6 \\
(12)\end{array}$ & $\begin{array}{l}4 \\
\text { (6) }\end{array}$ & $\begin{array}{l}2 \\
(\mathrm{~S})\end{array}$ & $\begin{array}{l}\text { Front moving from west. Temps } 20 \text { s and } \\
30 \mathrm{~s} F \text {. Windy from SE. Aircraft icing } \\
6000-9000 \mathrm{ft} \text {. Aircraft incloud and between layers. } \\
\text { Some event samples out until } 1 / 26 \text {. }\end{array}$ \\
\hline $\begin{array}{c}1 / 27 / 86 \\
\text { Mon }\end{array}$ & $\begin{array}{l}\text { Light to mdt snow. } \\
\text { Syracuse on back } \\
\text { side of deep low. }\end{array}$ & QA, KA & 3 & $\begin{array}{l}2 \\
(13)\end{array}$ & $\begin{array}{l}3 \\
\text { (5) }\end{array}$ & $\begin{array}{c}2 \\
\text { (2) }\end{array}$ & $\begin{array}{l}2 \\
\text { (S) }\end{array}$ & $\begin{array}{l}\text { Much colder, } 28 \mathrm{~F} \text { to } 7 \mathrm{~F} \text {. Windy from the } \\
\text { NW. Lake effect snow developed over Lk. } \\
\text { Ontario in the afternoon. }\end{array}$ \\
\hline $\begin{array}{c}1 / 28 / 86 \\
\text { Tue }\end{array}$ & $\begin{array}{l}\text { Lt snow a.m. Clrg } \\
\text { in afternoon. }\end{array}$ & QA & 0 & $\begin{array}{l}3 \\
(15)\end{array}$ & $\begin{array}{c}13 \\
(16)\end{array}$ & $\begin{array}{l}2 \\
(4)\end{array}$ & $\begin{array}{c}1 \\
(S)\end{array}$ & $\begin{array}{l}\text { QA made two flights. KA is no longer in } \\
\text { PRECP. Lake-efiect snow at Sandy Pond all day } \\
\text { with 5-in. accumulation. }\end{array}$ \\
\hline $\begin{array}{c}1 / 29 / 86 \\
\text { Wed }\end{array}$ & $\begin{array}{l}\text { Thickening and } \\
\text { lowering ovc. KF } \\
\text { approaching. Lt } \\
\text { snow in advance of } \\
\text { low pressure center. }\end{array}$ & QA, DC-3 & 2 & $\begin{array}{l}0 \\
\text { (0) }\end{array}$ & $\begin{array}{l}14 \\
(15)\end{array}$ & $\begin{array}{c}2 \\
\text { (3) }\end{array}$ & $\begin{array}{l}1 \\
\text { (S) }\end{array}$ & $\begin{array}{l}\text { "Alberta Clipper" type storm produced } \\
\text { light snow, but not much accumulation. } \\
\text { Cold. }\end{array}$ \\
\hline $\begin{array}{c}1 / 31 / 86 \\
\text { Fri }\end{array}$ & $\begin{array}{l}\text { Low ovc AM with } \\
\text { intmt snow. } \\
\text { Later lake effect } \\
\text { snow. }\end{array}$ & QA, DC-3 & 2 & $\begin{array}{c}2 \\
(6)\end{array}$ & $\begin{array}{l}8 \\
(8)\end{array}$ & $\begin{array}{l}2 \\
\text { (2) }\end{array}$ & $\begin{array}{l}1 \\
\text { (S) }\end{array}$ & $\begin{array}{l}\text { Snow appeared to be from combination of } \\
\text { lake effect/orographic. Intensity varied } \\
\text { from intermittent to moderate. Syracuse, } \\
\text { Boonville, and Sandy Pond all got snow. Aircraft } \\
\text { characterized the lake effect and orographic } \\
\text { clouds and precipitation. }\end{array}$ \\
\hline
\end{tabular}


TABLE 5a. (contd)

\begin{tabular}{|c|c|c|c|c|c|c|c|c|}
\hline Date & Weather Summary & NCFlights & $\begin{array}{l}\text { BNV } \\
\text { RS }\end{array}$ & $\begin{array}{l}\text { S } \\
\mathbf{E} \\
\text { g(a) }\end{array}$ & $\begin{array}{l}E \\
V \\
N \\
T(a) \\
\end{array}$ & $\begin{array}{l}\mathbf{F} \\
\underline{P(a)}\end{array}$ & $\begin{array}{l}5 \\
C \\
1 \\
T(a)\end{array}$ & Remarks \\
\hline $\begin{array}{c}2 / 1 / 86 \\
\text { Sat }\end{array}$ & $\begin{array}{l}\text { Pre-WF overrun- } \\
\text { ning. Lt snow } \\
\text { changing to IP } \\
\text { and then to } Z R \text {. }\end{array}$ & QA, DC-3 & 3 & $\begin{array}{c}1 \\
\text { (4) }\end{array}$ & $\begin{array}{c}11 \\
(19)\end{array}$ & $\begin{array}{c}4 \\
(5)\end{array}$ & $\begin{array}{c}1 \\
\text { (S) }\end{array}$ & $\begin{array}{l}\text { Low layers of atmosphere were very dry. } \\
\text { Precipitation was very slow to start. } \\
\text { Snow changed to ice pellets and then to } \\
\text { freezing rain as WF neared Syracuse. Cold, } 20 \mathrm{~F} \text {. } \\
\text { Eleven of the event samples out until } 2 / 2 \text {. SCIT } \\
\text { sample was not picked up until } 1130 \text { on } 2 / 4 \text {. }\end{array}$ \\
\hline $\begin{array}{r}\text { /3/86 } \\
\text { Mon }\end{array}$ & Low ove. all day. & QA, DC-3 & 0 & 0 & 0 & 0 & 0 & $\begin{array}{l}\text { The } 2 \text { aircraft made intercomparison } \\
\text { flights over Lake. Ontario at several levels. No } \\
\text { precipitation. }\end{array}$ \\
\hline $\begin{array}{c}2 / 4 / 86 \\
\text { Tue }\end{array}$ & $\begin{array}{l}\text { Slow warm front } \\
\text { from SW. Precip } \\
\text { was in form of ZR. }\end{array}$ & QA, DC-3 & 4 & $\begin{array}{c}0 \\
(0)\end{array}$ & $\begin{array}{c}15 \\
(19)\end{array}$ & $\begin{array}{c}3 \\
(5)\end{array}$ & $\begin{array}{c}1 \\
\text { (R) }\end{array}$ & $\begin{array}{l}\text { The large precipitation area associated with the } \\
\text { frontal system took nearly all day to reach Syracuse } \\
\text { from western New York. The precipitation began as } \\
Z \text { at Syracuse at } 1700 \text { and continued most of the } \\
\text { night. At least } 14 \text { of the event samples were out until } \\
2 / 5 \text {. The SCIT samples from } 2 / 1 \text { were picked up at } \\
1130,2 / 4 \text { before precipitation began. New SCITsam } \\
\text { samples were set out for the period } 1130,2 / 4 \text { to } 1130,2 /\end{array}$ \\
\hline
\end{tabular}

ABBREVIATIONS:

$\mathrm{QA}=\mathrm{BNL}$ Queen Air

KA = NOAA King Air

DC-3 = PNLDC-3

RS = Boonville Rawinsonde

SEQ = Surface Sequential sampling site

EVNT = Surface Event sampling site

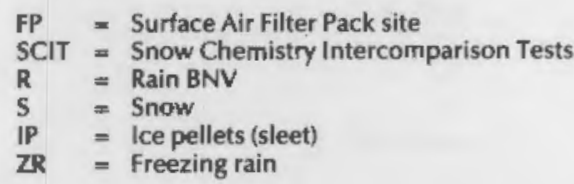

(a) Top number is the total number of sites activated, bottom number in parentheses is the total number of samples collected.

move northeastward as the day progressed. A rather poorly defined warm front was located from Michigan through northern Ohio and southward into West Virginia, but moved northward during the day. A cold front extended southward from the center of the low and passed through eastern Ohio to central Tennessee and southward. A weak arctic front followed this cold front. Cirrostratus clouds increased after midnight, becoming overcast before dawn. The clouds lowered and thickened, producing an altostratus / altocumulus overcast during the morning as the cold front approached Syracuse. There were a few sprinkles of rain late in the day at Syracuse, but cells of light rain and graupel accompanying the cold front occurred at Sandy Pond and Boonville. The cold front passed Syracuse at about noon EST, dropping the temperature from $48^{\circ} \mathrm{F}$ to about $40^{\circ} \mathrm{F}$. The arctic front passed at about 1900 EST, lowering the temperatures from the $30^{\prime}$ 's to the $20^{\prime} \mathrm{s}\left({ }^{\circ} \mathrm{F}\right)$.

\section{Aircraft Operations on January 22}

Al1 three aircraft flew on January 22 . The DC-3 operated between 0900 and 1300 EST, flying an east-west leg over Boonville; circling above Boonville; and flying a north-south pattern north of Syracuse just inland from Lake Ontario. Several precipitation and cloud water samples were collected by the $D C-3$. The Queen Air flew between 0730 and 1115 EST, traversing on an east-west leg through the south of the network and on a north-south leg along the western edge of the network. The entire flight was spent in precold-front air. The Queen Air also was successful in collecting both cloud and rain 
TABLE 5b. Aircraft Mission Summary For PRECP-III

\begin{tabular}{|c|c|c|c|c|c|c|c|c|}
\hline \multirow[b]{2}{*}{ Date } & \multirow[b]{2}{*}{ Aircraft } & \multirow{2}{*}{$\begin{array}{l}\text { Flight Times } \\
\text { (GMT) }\end{array}$} & \multirow{2}{*}{$\begin{array}{l}\text { Altitudes } \\
\text { (Kft MSL) }\end{array}$} & \multicolumn{5}{|c|}{ Integrated Samples } \\
\hline & & & & FP & RW & CW & $\underline{\mathrm{SN}}$ & Impactor \\
\hline \multirow[t]{2}{*}{$1-13$} & QA & $1839-2122$ & 2.5 & 1 & & & & \\
\hline & & & 4.5 & 1 & & & & \\
\hline \multirow[t]{2}{*}{$1-15$} & QA & $1846-2052$ & 2 & 1 & & & & \\
\hline & & & 6 & 1 & & & & \\
\hline \multirow[t]{3}{*}{$1-17$} & KA & $1800-2100$ & 2 & 1 & & & & \\
\hline & DC-3 & $1825-2230$ & 2.5 & 2 & 6 & & & \\
\hline & & & 5 & & 1 & 4 & & \\
\hline $1-18$ & KA & $1830-2230$ & 2.5 & 2 & & & & \\
\hline \multirow[t]{9}{*}{$1-19$} & QA & $1322-1706$ & 4 & 3 & 4 & & & \\
\hline & & & 6 & 1 & 1 & & & \\
\hline & KA & $1735-2130$ & 3.5 & 3 & & & & \\
\hline & & & 13 & & 1 & & & \\
\hline & & 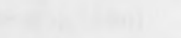 & 11 & & 1 & & & \\
\hline & & & 9 & & & 1 & & \\
\hline & DC-3 & $2115-0115$ & 4 & 2 & 3 & 4 & & 1 \\
\hline & & & 5 & 2 & 2 & 1 & & \\
\hline & & & 9 & 2 & & & 4 & \\
\hline \multirow[t]{6}{*}{$1-20$} & QA & $1322-1719$ & 4 & 2 & 6 & 4 & & \\
\hline & & & 6 & 2 & 5 & 4 & & \\
\hline & KA & $1815-2210$ & 8 & 1 & & 3 & & \\
\hline & & & 5 & 1 & & & & \\
\hline & DC-3 & $2023-2240$ & 5 & 2 & 2 & & 2 & \\
\hline & & & 6 & & & 2 & 4 & \\
\hline \multirow[t]{10}{*}{$1-22$} & QA & $1237-1617$ & 5 & 1 & & & & \\
\hline & & & 3.5 & 2 & & & & \\
\hline & & & 3 & & 1 & 1 & & \\
\hline & & & 4 & 1 & & & & \\
\hline & DC-3 & $1405-1810$ & 5 & 2 & 4 & 2 & & 1 \\
\hline & & & 7 & 2 & 2 & 4 & 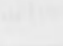 & \\
\hline & & & 9 & 2 & & & 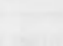 & \\
\hline & & & 3 & 2 & & 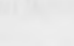 & 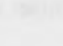 & . \\
\hline & KA & $1803-2135$ & 5 & 1 & & & & \\
\hline & & & 12 & 2 & & & & \\
\hline \multirow[t]{6}{*}{$1-25$} & QA & $1826-2158$ & 3.2 & 2 & & 2 & & \\
\hline & & & 4 & 1 & & 2 & & \\
\hline & & & 6 & 1 & & 1 & & \\
\hline & KA & $2110-0024$ & 15 & 1 & & & 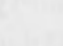 & \\
\hline & & & 9 & 1 & & & & \\
\hline & & & 6 & 1 & & & . & \\
\hline \multirow[t]{7}{*}{$1-27$} & QA & $1802-2125$ & 3 & 1 & & & 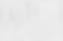 & 1 \\
\hline & & & 4 & 1 & & 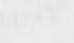 & & 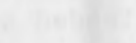 \\
\hline & & & 5 & 1 & & & & \\
\hline & KA & $1900-2250$ & 10 & 2 & 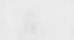 & & & \\
\hline & & & 7 & 2 & & & & \\
\hline & & & 5 & 2 & & & 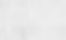 & \\
\hline & & & 3 & 1 & & & & \\
\hline \multirow[t]{3}{*}{$1-28$} & QA & $1410-1650$ & 5 & 1 & & ( & 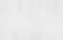 & \\
\hline & & & 3 & 1 & & & & \\
\hline & QA & 2028-2139 & 4 & 1 & & & & \\
\hline $1-29$ & $Q A$ & $1905-2133$ & 10 & 1 & & & & \\
\hline & & & 8 & 1 & & & 1 & \\
\hline & DC-3 & $1910-2120$ & 5 & 4 & & & & \\
\hline $1-31$ & QA & $1545-2000$ & 5 & 1 & & & & \\
\hline & & & 2 & 1 & & & & \\
\hline & & & 2.8 & 1 & & & & \\
\hline & & 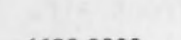 & 4 & 1 & & & & \\
\hline & DC-3 & $1620-2000$ & 1.6 & 2 & & & & 1 \\
\hline & & & 5 & 2 & & & 3 & \\
\hline & & & 4 & & & & 1 & \\
\hline
\end{tabular}


TABLE 5b. (contd)

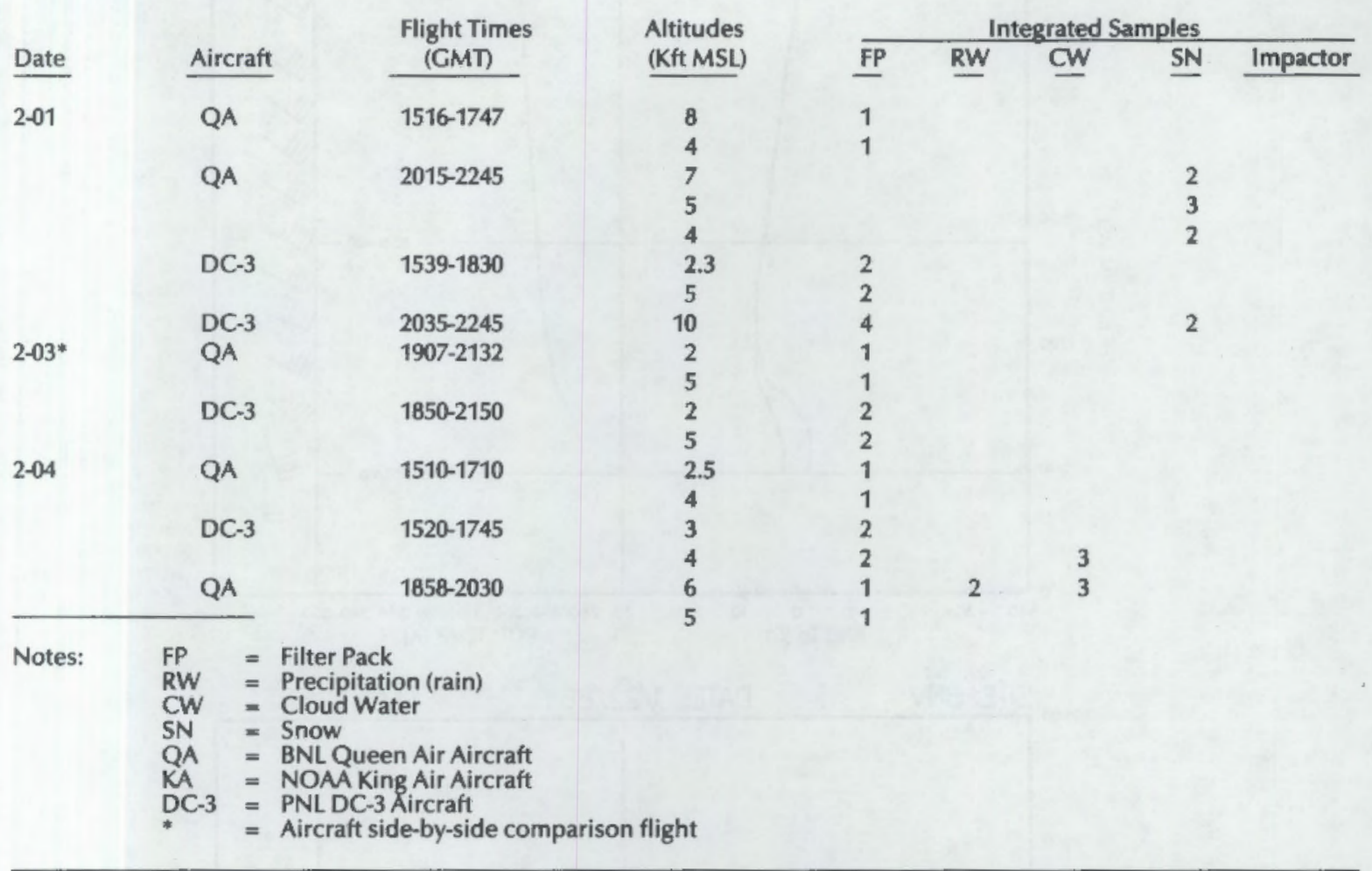

water. The King Air flew from 1300 EST to 1630 EST. It traversed between the cold front that had passed Syracuse at about noon and the arctic front that was approaching. There were indications that some legs of the flight penetrated into the arctic air.

\section{Surface Operations on January 22}

Surface operations were activated to collect. event samples at the network sites and sequential samples at Boonville. Eleven precipitation samples were collected at 10 event sites and a series of 3 sequential samples were collected at Boonville. Nine high-volume filters were collected at 4 sites, providing data to describe the air chemistry in the pre-frontal air mass in the warm sector, in the cool air mass behind the first front, and in the arctic air behind the second front.

4. Preliminary Results from the PNL Data Set for January 22

Figure 3 shows the temperature and wind profiles acquired by the PNL rawinsonde (located at Boonville) for 1000 EST (Figure $3 a$ ) and 1400 EST (Figure 3b). These data indicate how conditions changed with the passage of the first cold front at Boonville, which occurred at approximately 1230 EST. The average decrease in temperature at all altitudes following the frontal passage was approximately $9^{\circ} \mathrm{F}\left(5^{\circ} \mathrm{C}\right)$. The $1400 \mathrm{EST}$ wind profile showed that, following the frontal passage, the winds backed to the west relative to the earlier sounding. The vertical shear of the horizontal wind shown in Figure $3 \mathrm{~b}$ also indicated pronounced backing of the wind with altitude, implying cold air advection.

A portion of the $O C-3^{\prime} s$ flight path for this day is given in Figure 4. Between approximately 1215 EST and 1300 EST, the DC-3 was flying a narrow box pattern north of Syracuse at an elevation of $3000 \mathrm{ft}$. Shortly before, the first surface cold front had passed through Syracuse. Figure 5 shows the variations in temperature and dewpoint as a function of time during this portion of the flight. At approximately 1227 EST, there was a noticeable decrease in the ambient 

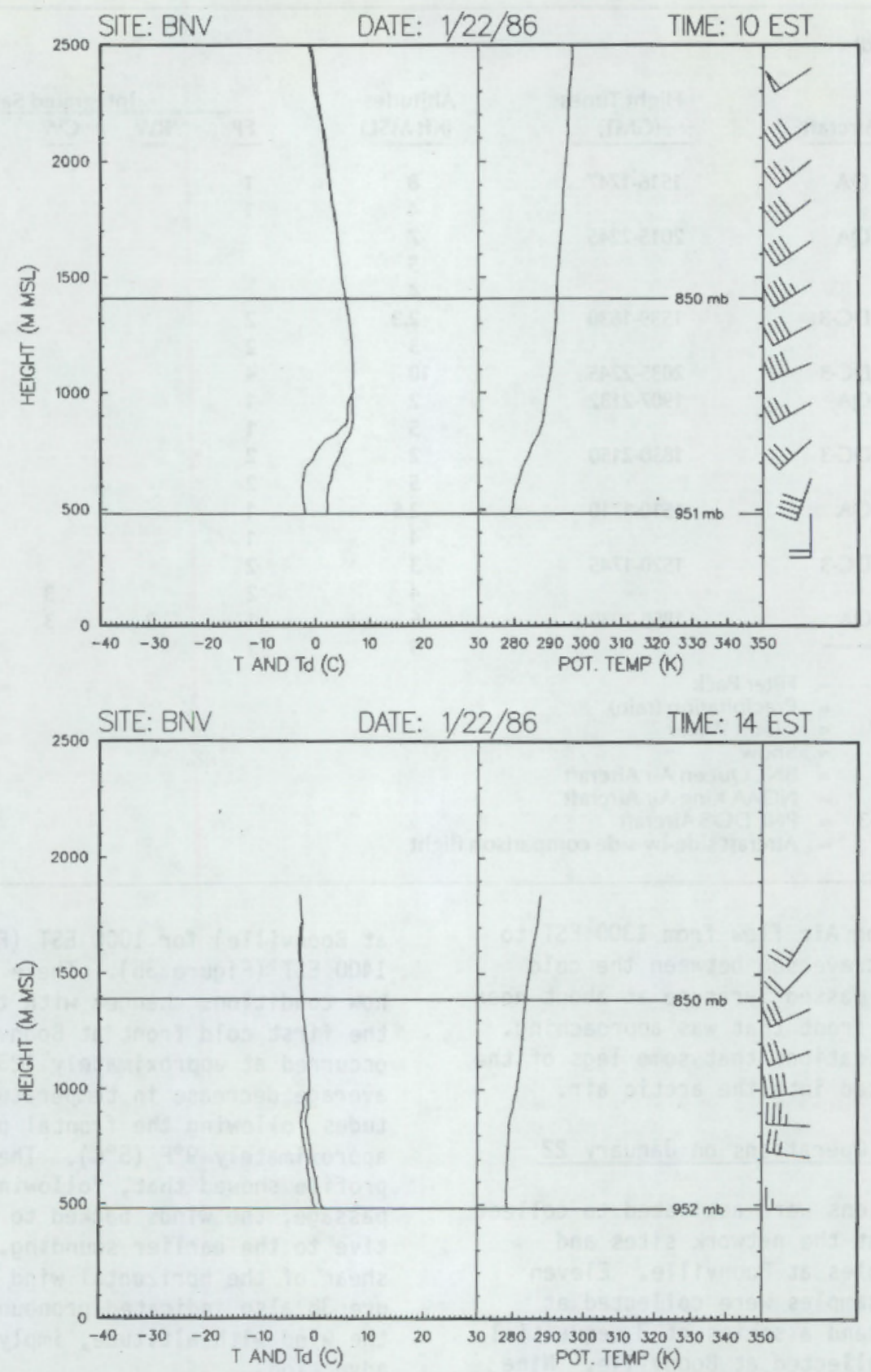

FIGURE 3. BNV Rawinsonde Profiles for January 22, 1986. Temperature and dew point are plotted in the left panel; potential temperature is shown in the center panel; the wind profile is indicated in the right panel (half bar $=2.5 \mathrm{~ms}^{-1}$, whole bar $=5 \mathrm{~ms}-1$, flag = $25 \mathrm{~ms}^{-1}$ ). (a) 1000 EST; (b) 1400 EST.

temperature and dewpoint values, which suggests that the $D C-3$ had penetrated the frontal zone, passing from the pre-frontal to the post-frontal air mass. The temperature difference was approximately $4^{\circ}$ to $5^{\circ} \mathrm{C}$, which agreed with the conditions observed in the Boonville rawinsonde soundings given in Figure 3. The temperature and dew-point data presented in Figure 5 suggest that the flight path brought the $\mathrm{DC}-3$ back into the prefrontal air mass at 1254 EST.

The $\mathrm{NO}_{\mathrm{x}}$ and $\mathrm{O}_{3}$ profiles for this portion of the flight are also shown in Figure 5 (note that the instruments were zeroed at 1220 and again at 1255 EST, as done typically at each 


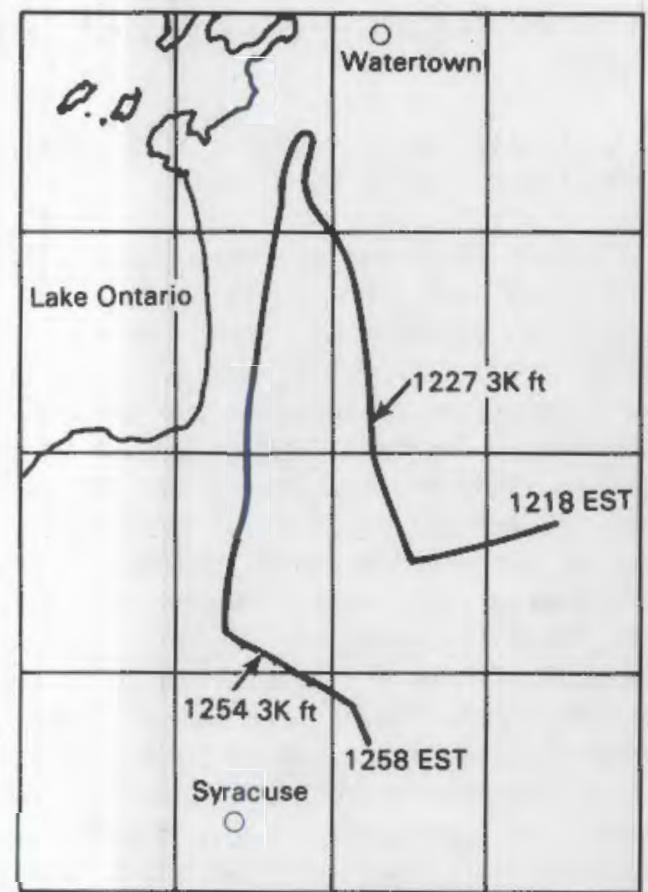

FIGURE 4. Flight Path of DC-3 Between 1215 and 1300 EST, January 22, 1986. flight level). Values of $\mathrm{NO}_{x}$ observed at $3000 \mathrm{ft}$ before 1227 indicated an average mixing ratio of approximately $17 \mathrm{ppb}$; the $0_{3}$ mixing ratio averaged $15 \mathrm{ppb}$. At about 1227 , NO $x$ values dropped to roughly $5 \mathrm{ppb}$ and continued at this level for the remainder of the 3000-ft pattern. The expected anticorrelation between $\mathrm{NO}_{x}$ and $\mathrm{O}_{3}$ is evident in these data. These data strongly suggest that indeed the $D C-3$ penetrated the frontal zone and that pollutant concentrations from two different air masses were observed. Data from the King Air's afternoon mission (shown in Figure 9 of the preceding article in this volume) revealed that pollutant concentrations were again different between the cool air behind the first front and the cold air mass behind the arctic front.

The complete data set for the January $22 \mathrm{mis}-$ sion will provide an interesting opportunity to investigate the temporal evolution of scavenging processes. This case has been selected for study by the RADM group at NCAR. Both the PRECP and RAOM programs will

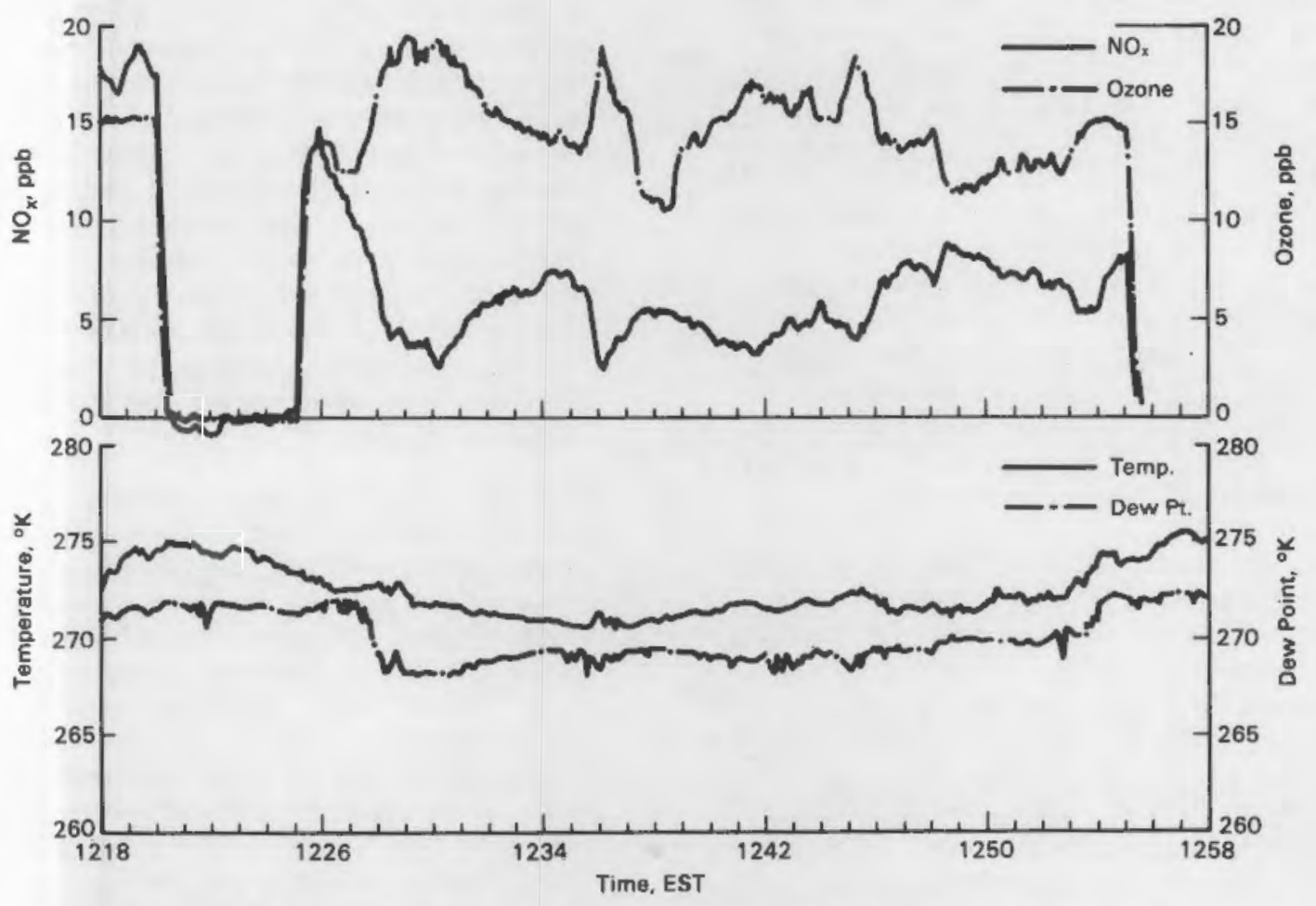

FIGURE 5. Temperature, Dew Point, $\mathrm{NO}_{\mathrm{x}}$, and Ozone Profiles Recorded by the DC-3 Instrumentation Between 1215 and 1300 EST, January 22, 1986. 
benefit from the observational and numerical analyses that will be produced from this mission.

\section{Summary}

The variety of storm systems studied during PRECP-III and the success of both the aircraft and surface components of the study bodes well for the overall success of the program. At this time, the final data sets are nearly complete and preliminary analyses have begun. Expectations are high that the results of the Syracuse study will provide many new insights into the processing of air pollutants by winter storms.

\section{Acknowledgments}

Substantial technical and logistical contributions to the success of PNL's efforts during PRECP-III were made by D. S. Daly, G. W. Dennis, J. L. Gregory, J. M. Hales, R. V. Hannigan, G. L. Laws, and R. N. Lee.

\section{REFERENCES}

Busness, K. M., et al. 1986. "PNL's Contributions to the PRECP-I (APRIL) Field Studies." In Pacific Northwest Laboratory Annual Report for 1985 to the DOE Office of Energy Research: Part 3-Atmospheric Sciences. PNL-5750 PT3, pp. 44-54, Pacific Northwest Laboratory, Richland, Washington.

Daly, 0. S., et al. 1986. "PNL's Contributions to PRECP-II (PRESTORM)." In Pacific Northwest Laboratory Annual Report for 1985 to the DOE Office of Energy Research: Part 3 - Atmospheric Sciences. PNL -5750 PT3, pp. 54-64, Pacific Northwest Laboratory, Richland, Washington.

Slinn, W. G. N., et al. 1986. "The PRECP Program--Pacific Northwest Laboratory's Contribution to the Department of Energy's Multilaboratory Study of the Processing of Emissions by Clouds and Precipitation." In Pacific Northwest Laboratory Annual Report for 1985 to the DOE Office of Energy Research: Part 3-Atmospheric Sciences. PNL-5750 PT3, pp. 37-44, Pacific Northwest laboratory, Richland, Washington.
PNL 'S CONTRIBUTION TO PRECP-IV (GALE) FIELD STUDIES

A. C. Leslie, K. M. Busness, M. T. Dana, J. M. Thorp, and W. G. N. Slinn

The fourth PRECP field program, PRECP-IV, took place over the 2-month period of January 15 to March 15, 1986. PRECP-IV was based at Raleigh-Durham, North Carolina, and the program was designed to run concurrently with GALE. The basic objectives of PRECP-IV were to study the processing and wet deposition of chemical species (in particular, sulfur and nitrogen) at three scales: 1) for rainbands within frontal storms, 2) for entire frontal storms, and 3) for the regional scale, i.e., for a single storm as it progressed across the eastern United States. PRECP-IV was constructed to take advantage of the opportunity presented by the GALE meteorological measurements. Thus, PRECP-IV was a chemical measurement program within the experimental domain of GALE.

The core objectives of GALE were 1) to describe the airflow, mass, and moisture fields in East-Coast winter storms, with special emphasis on regional-scale and air-sea interaction processes, 2) to understand the physical mechanisms controlling the formation and rapid development of these storms, and 3) to develop and test computerized models for their prediction. The weather associated with these storms can be severe and frequently is poorly predicted by current forecasting models. The comprehensive meteorological data base generated in GALE would otherwise have been beyond the financial resources of PRECP.

GALE was one of the major meteorological studies of this decade, involving approximately 200 scientists, engineers, and technicians from over 25 research groups in the United States. Figures 1 and 2 show the extent of GALE surface measurements. As these figures show, extensive ground-based measurements, rawinsonde and dropwindsonde measurements, and aircraft measurements were made. Nine research aircraft were devoted to the basic GALE study: NOAA's $\mathrm{P}-3$ and Citation, NCAR's Sabreliner, Electra, and King 


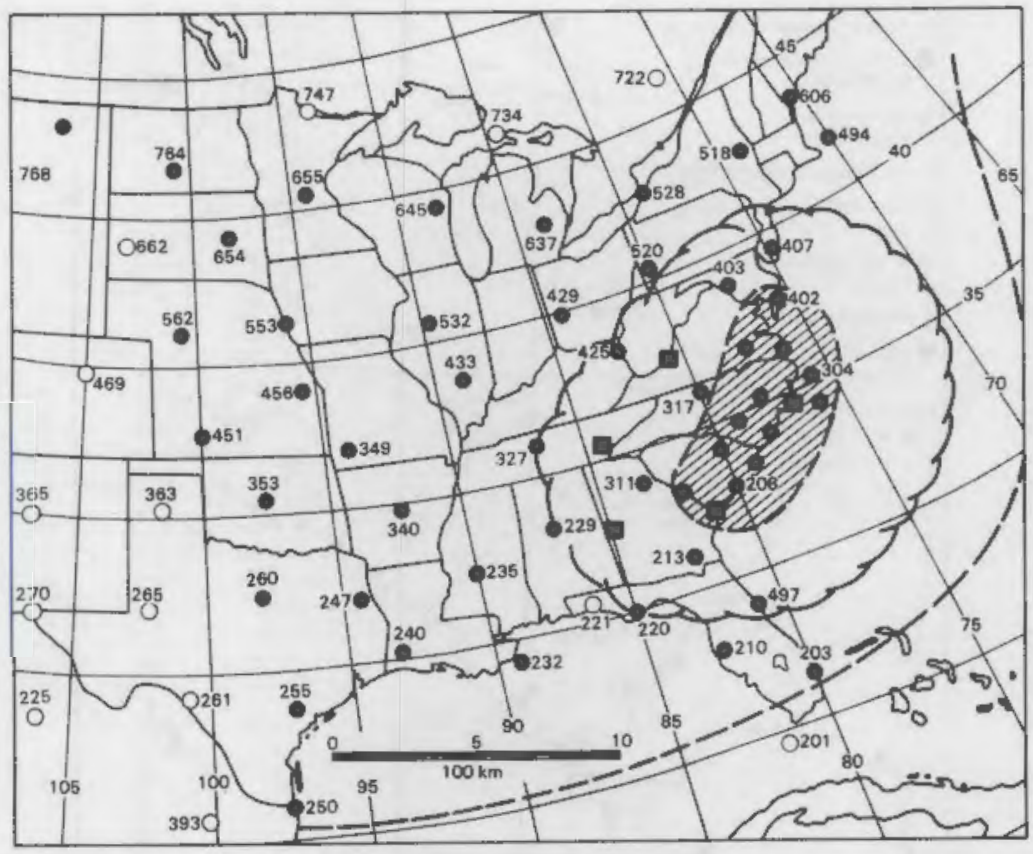

FIGURE 1. GALE Experimental Areas. In the outer GALE area, solid circles show sites for 3-h NWS rawinsonde releases, and the dashed line shows maximum offshore extent of drop-windsondes. The regional GALE area (scalloped boundary) includes enhanced surface and upper-air observations, digitally recorded NWS radar data, and special drop-windsondes. The inner GALE area (shaded) contains special facilities detailed in Figure 2.

Air, NASA's Electra and ER-2, the University of Washington's C-131A (Convair), and an MIT Beechcraft Baron. In addition, a singleengine Cessna was operated by North Carolina State University (NCSU) for chaff dispersion, and a number of dropwindsonde missions were flown by the U.S. Air Force. Full details of the GALE program can be found in the GALE Operations Plan (NCAR 1986).

The PRECP-IV/GALE study was given the secondorder acronym GAPS, an abbreviation for GALE Acidic Precipitation Studies, suggesting that PRECP would fill GAPS in GALE by adding a chemistry component. With the involvement in GALE, there were by necessity distinct components to the PRECP-IV/GAPS program design and these are briefly listed below.

- Airborne chemistry sampling was carried out during the full 2-month period of GALE, using some of the GALE research aircraft as sampling platforms of opportunity.
- Airborne sampling dedicated to PRECP-IV was carried out also during a shorter time period, February 21 to March 3, 1986, using three PRECP aircraft.

- Three different ground-based precipitation networks were operated during the full 2-month period in conjunction with the three scales of the studies.

- During the Syracuse-based PRECP-III study from January 15 to February 10, 1986, contact with the GALE study was maintained in the event that the tracking of a major storm system moving north along the Atlantic coast could be conducted from the Syracuse base of PRECP-III.

\section{GAPS Objectives and Goals}

The PRECP-IV studies focused on three distinct spatial and temporal scales: rainbands within fronts (meso-gamma scale), fronts (meso-beta scale), and regional weather events (meso-alpha scale). Each of these studies had a set of goals as outlined below. 


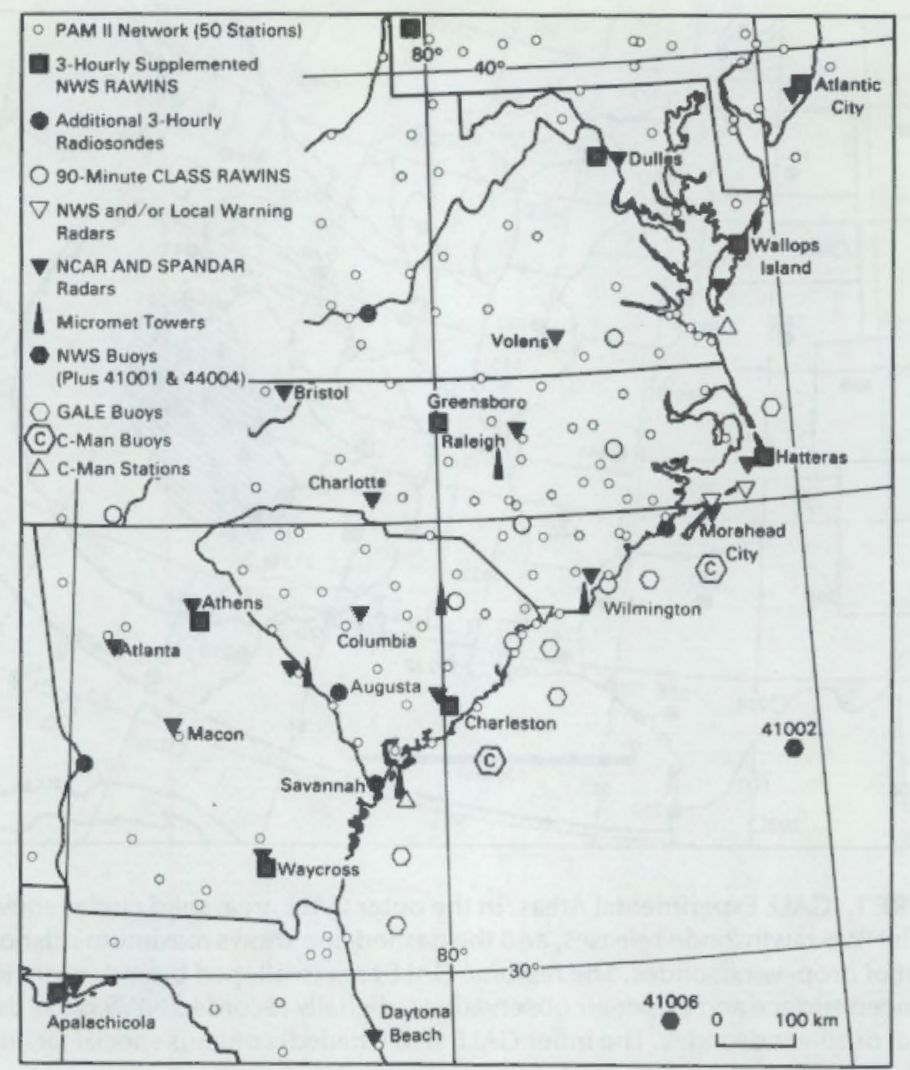

FIGURE 2. GALE Special Surface-Based Observational Facilities.

\section{Goals of Rainband Studies}

The overall objective of the rainband studies was to understand the processing, deposition, and disposition of various trace chemicals (especially sulfur and nitrogen compounds) by and at the scale of rainbands within frontal storms. Within this overall objective were contained the following goals:

- compare chemical and water fluxes for individual rainbands

- define the efficiency of nucleation scavenging

- define the in-storm distributions of $\mathrm{H}_{2} \mathrm{O}_{2}$ and $\mathrm{O}_{3}$

- examine the in-storm production of $\mathrm{SO}_{4}=$ and $\mathrm{NO}_{3}{ }^{-}$

- define the relative scavenging rates for species with different chemical and cloudmicrophysical reactivities
- estimate the scavenging efficiencies and inefficiencies for different species and for different rainbands within individual storms.

\section{Goals of Frontal-Storm Studies}

The overall objective of the frontal-storm studies was to increase understanding of the processing of pollutants and other chemicals by and at the scale of entire frontal storms. Within this overall objective were contained the following goals:

- compare inflow and deposited acidity

- define the relative rates of scavenging for cloud-and chemical-active versus inactive species

- compare relative ratios of species in the inflow, outflow, and precipitation

- examine the production of $\mathrm{SO}_{4}=$ and $\mathrm{NO}_{3}{ }^{-}$. 


\section{Goals of Regional-Scale Studies}

The overall objective of the regional-scale studies was to examine the processing of pollutants by single storms as they progressed across eastern North America. Within this overall objective were contained the following goals:

(a) For cases with GALE-defined regionalscale meteorology, define regional-scale precipitation and air chemistry

(b) For the sub-cases of (a) with supporting airborne measurements, compare scavenging ratios based on surface versus aloft measurements of air concentrations for various species

(c) For cases in (b), when safety permits and especially for the case of offshore cyclogenesis with cold-air damming, determine the contribution of belowcloud scavenging to surface precipitation chemistry

(d) For the proposed case of regional-scale flights by some of the GALE aircraft, interpret surface precipitation chemistry in terms of inflow, in-cloud, and sub-cloud chenistry, and

(e) If possible, compare changes in inflow to outflow concentration ratios, especially as onshore storms progress across the surface network.

Resources and Facilities

\section{Aircraft}

During the 2-month period from January 15 to March 15, 1986, chemical instrumentation was supplemented by PRECP-IV/GAPS on three of the GALE aircraft: the NCAR Electra, the NCAR Sabreliner, and the NOAA P-3. A fourth GALE aircraft, the University of Washington's C-131A, was independently equipped for chemical measurement by the University of Washington, primarily in association with the chemical characterization of rainbands. Table 1 details the chemical instrumentation used on each of the GALE aircraft. The chemical instrumentation of the NCAR Electra and its operation on behalf of PRECP-IV was Subcontracted by PRECP to the University of Denver. The flight plans of these aircraft
TABLE 1. GALE Aircraft Chemical Capabilities

Instruments:
$\mathrm{H}_{2} \mathrm{O}_{2}$ (air)
$\mathrm{CO}$
$\mathrm{O}_{3}$

were dedicated to the GALE mission. However, while flying in GALE, chemical information relevant to the objectives of the rainband, frontal, and regional PRECP-IV/GAPS studies was collected.

In the period from February 21 to March 3, 1986, three aircraft were operated at

Raleigh-Durham, North Carolina, exclusively dedicated to PRECP-IV. The aircraft were the PNL $O C-3$, the BNL Queen Air, and the NOAA King Air. Their measurement capabilities are detailed in Table 2 (and in Table 2 of the preceding article in this volume).

\section{Surface Measurements}

Rainband Studies. For this study, the GALE meteorological support facility of the NCAR dual Doppler at Cape Hatteras, North Carolina, played a pivotal planning role. Figure 3 shows the location and areal coverage of the dual Doppler at Cape Hatteras as well as other surface radar sites used in GALE.

The primary PRECP effort in the rainband study was the establishment and operation of a 10-site precipitation chemistry network in 
TABLE 2. PRECP-IV Aircraft Measurement Capabilities

\begin{tabular}{ccc}
$\begin{array}{cc}\text { NOAA } \\
\text { King Air }\end{array}$ & $\begin{array}{c}\text { BNL } \\
\text { Queen Air }\end{array}$ & PNL-3 \\
\hline
\end{tabular}

Instruments:

$\mathrm{CO}$

$\mathrm{O}_{3}$

$\mathrm{SO}_{2}$

$\mathrm{SO}_{4}$

$\mathrm{NO}_{x}$

$b_{\text {scat }}$

Turbulence

Pressure/Altitude

Temperature

Dewpoint Temp.

Relative Humidity

UV

Liquid Water Content

Position

Winds

Filter Pack:

Aerosol lons

Metals

$\mathrm{SO}_{2}$

$\mathrm{HNO}_{3}$

$\mathrm{NH}_{3}$

Other:

$\mathrm{H}_{2} \mathrm{O}_{2}$ (water)

Trace Metais

Cloud Water

Precipitation

Ice/Snow

Particles:

$\operatorname{ASASP}(0.1-3 \mu \mathrm{m})$

$\operatorname{FSSP}(0.5-50 \mu \mathrm{m})$

2DC $(25-800 \mu \mathrm{m})$

$\operatorname{EAA}(0.01-1 \mu \mathrm{m})$

Climet $(0.3-2 \mu \mathrm{m})$

the Cape Hatteras area under the coverage of the dual Doppler at Cape Hatteras. The location of the samplers is shown in Figure 4. Sequential precipitation collection was made at each site using automatic sequentialcollectors. Event samples were also collected. At a single site of the 10-site network, filter samples were collected for $\mathrm{SO}_{2}, \mathrm{HNO}_{3}, \mathrm{NH}_{3}$ and aerosol ions.

Frontal Studies. A five-site network for sequential precipitation collection was

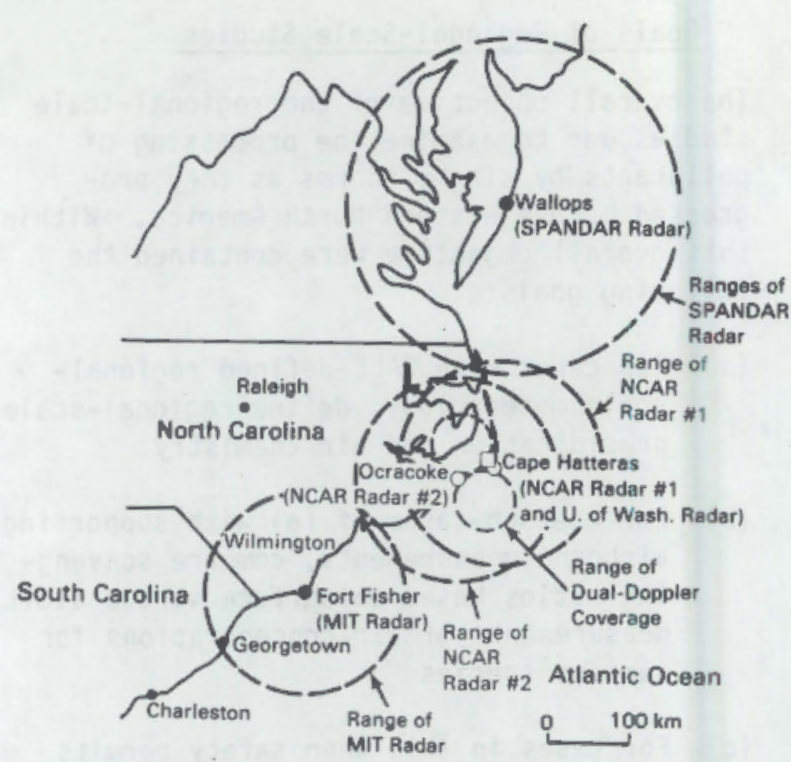

FIGURE 3. Doppler Radar Network for GALE. Circles indicate ground-based Doppler radars: NASA SPANDAR (SPA), NCAR, NCAR CP-3, NCAR CP-4, and MIT C-band. Range circles are at 200,140,140, and $140 \mathrm{~km}$. University of Washington TPQ-11 is shown by a square.

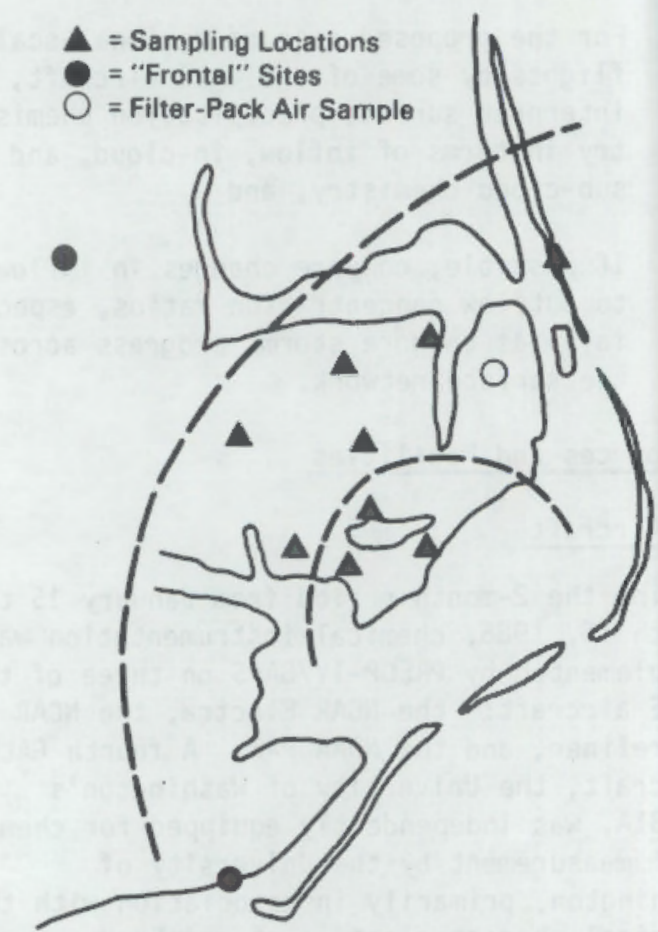

FIGURE 4. Rainband Studies Surface Network, January 15 to March 15 . 
established in North Carolina and operated when required over the 2-month period from January 15 to March 15, 1986. At two sites, filter samplers were deployed $\left(\mathrm{SO}_{2}, \mathrm{HNO}_{3}\right.$, $\mathrm{NH}_{3}$, and aerosol ions). The sites are shown in Table 3. Three of the sites were operated under contract to PNL by NCSU. Two of the sites were operated (gratis) by the University of North Carolina (UNC).

Regional-Scale Surface Sampling. For regional-scale precipitation chemistry sampling, arrangements were made to auginent six of the 24-hour UAPSP, MAP3S, and CAPMON (a) sites for sequential sampling. The locations of these six sites were in Georgia (Atlanta), Tennessee (Oak Ridge), North Carolina (Research Triangle Park), Delaware, New York (Brookhaven National Laboratory, Upton), and Pennsyivania (Pennsylvania State University).

\section{Operations}

The data base of meteorological measurements available to PRECP-IV is described in the GALE Field Program Sumnary (Drexel University 1986). The full GALE program was activated on "alert" status for 33 days of the 60-day program period.

\section{GALE Aircraft.}

Use of the GALE aircraft during the 2-month period, January 15 to March 15, was primarily directed toward two studies: the regional

TABLE 3. Frontal Network Sites

\begin{tabular}{|c|c|c|}
\hline Location & Measurement & $\begin{array}{l}\text { Operating } \\
\text { Agency }\end{array}$ \\
\hline Raleigh & $\begin{array}{l}\text { Sequential/event } \\
\text { precip. }\end{array}$ & $\mathrm{NCSU}$ \\
\hline Raleigh & Filter & PNL \\
\hline Clinton & $\begin{array}{l}\text { Sequential/event } \\
\text { precip. }\end{array}$ & NCSU \\
\hline Lewiston & $\begin{array}{l}\text { Sequential/event } \\
\text { precip. }\end{array}$ & NCSU \\
\hline Moorehead City & $\begin{array}{l}\text { Sequential/event } \\
\text { precip. }\end{array}$ & UNC \\
\hline Wilmington & $\begin{array}{l}\text { Sequential/event } \\
\text { precip. }\end{array}$ & UNC \\
\hline Wilmington & Filter & UNC \\
\hline
\end{tabular}

(a) Canadian Precipitation Monitoring Network (CAPMON). characterization study and the rainband study. In the case of the latter, the primary aircraft platform was the University of Washington's C-131A.

\section{Network Surface Sampling}

The 10 -site rainband network was primarily used in the meso-gama scale studies. However, this network (or a 1 or 2 station subset of it) was also used as an extension of the frontal network and hence applied during frontal (meso-beta) studies. Both the rainband and the frontal networks were used during the 2-rnonth period January 15 to March 15, 1986, either in association with airborne sampling from the GALE aircraft and/or during the intensive study period February 21 to March 3, using the three PRECP aircraft. The regional network operated fully only on February 10 and March 13, 1986, when major precipitation systems swept across the eastern United States.

Study Periods

\section{Surface Precipitation Sampling}

Rainband Study. Twelve events were sampled, with a total of approximately 75 event samples and 75 sets of sequential samples taken. Table 4 lists the sampling dates of the precipitation-chemistry collection.

Frontal Network. A total of 35 sequential and 35 event precipitation samples were collected. In some instances, the sample volumes were at trace or nil amounts. Table 5 lists the sampling dates and sites. In the case of the site at Wilmington, complete collection of all precipitation events prior to, during, and after the 60-day period January 15 to March 15, 1986, were made by UNC.

Surface Filter Sampling. Surface air sampling (using a two-filter stack for aerosols and $\mathrm{NH}_{3}$, and a three-filter stack for ions, $\mathrm{SO}_{2}$, and $\mathrm{HNO}_{3}$ ) was carried out coincident with precipitation sampling. Three sites were used: Raleigh, Wilmington, and one rainband site. The sampling dates were $86 / 01 / 19,86 / 02 / 06,86 / 02 / 21,86 / 02 / 24$, $86 / 02 / 25,86 / 02 / 26,86 / 03 / 01$, and $86 / 03 / 03$. (On $86 / 01 / 19$ at Raleigh, $\mathrm{NH}_{3}$ was not sampled.) At Raleigh (the Finley Farm site) a streaker filter sampler was operated between 
TABLE 4. Precipitation Chemistry Sampling Dates for Major Events at the GALE Rainband Study

\begin{tabular}{|c|c|c|c|c|c|c|c|c|c|c|c|}
\hline \multirow{3}{*}{$\begin{array}{l}\text { Event } \\
\text { ID(a) }\end{array}$} & \multicolumn{4}{|c|}{ Sampling Time(b) } & \multicolumn{4}{|c|}{ Precip. Time(c) } & \multirow{3}{*}{$\begin{array}{l}\text { Rain } \\
\mathrm{cm} \text { (d) }\end{array}$} & \multirow{2}{*}{\multicolumn{2}{|c|}{ Sites (e) }} \\
\hline & \multicolumn{2}{|c|}{ On } & \multicolumn{2}{|c|}{ Off } & \multicolumn{2}{|c|}{ Start } & \multicolumn{2}{|c|}{ Stop } & & & \\
\hline & $\overline{\text { Day }}$ & $\overline{\text { EST }}$ & $\overline{\text { Day }}$ & $\overline{\text { EST }}$ & $\overline{\text { Day }}$ & $\overline{E S T}$ & $\overline{\text { Day }}$ & $\overline{\text { EST }}$ & & Event & $\overline{\mathrm{Seq}}$ \\
\hline 0120 & 19 & 1030 & 20 & 1300 & & (trace) & & & 0.1 & 4 & 3 \\
\hline 0126 & 25 & 1130 & 26 & 1400 & 25 & 2000 & 26 & 0200 & 2.2 & 8 & 8 \\
\hline 0127 & 26 & 1030 & 27 & 1300 & 26 & 1500 & 27 & 0800 & 1.0 & 6 & 9 \\
\hline 0207 & 6 & 1330 & 7 & 1430 & & (trace) & & & 0.2 & 6 & 6 \\
\hline 0211 & 10 & 1200 & 11 & 1700 & 11 & 0000 & 11 & 0700 & 1.2 & 10 & 10 \\
\hline 0223 & 22 & 1300 & 23 & 1500 & 22 & 2330 & 23 & 0300 & 0.2 & 10 & 10 \\
\hline 0228 & 26 & 1100 & 28 & 1200 & 27 & 0900 & 27 & 1400 & 0.9 & 10 & 10 \\
\hline 0304 & 3 & 1100 & 4 & 1100 & 3 & 1600 & 3 & 1800 & 0.3 & 7 & 7 \\
\hline 0306 & 6 & 1100 & 6 & 1600 & 6 & 1300 & 6 & 1430 & 0.2 & 2 & 2 \\
\hline 0307 & 6 & 1300 & 7 & 1000 & 6 & 1300 & 6 & 1430 & 0.2 & 5 & 5 \\
\hline 0314 & 13 & 0900 & 14 & 1300 & 14 & 1230 & 14 & 1400 & 0.3 & 2 & 2 \\
\hline 0315 & 14 & 0900 & 15 & 0830 & 14 & 1130 & 14 & 1600 & 2.0 & 3 & 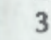 \\
\hline
\end{tabular}

(a) Nominally, the date of collection.

(b) Mean of all sampled sites.

(c) Mean of all sites with precipitation; times vary.

(d) Rough mean of all sites; amounts vary.

(e) Number of sites with a sample usable for analysis.

TABLE 5. Frontal Network 5ampling Dates

\begin{tabular}{|c|c|c|c|}
\hline Date & Site(a) & Date & Site(a) \\
\hline $86 / 01 / 19$ & $\begin{array}{l}\text { Clinton } \\
\text { Lewiston } \\
\text { Moorehead City } \\
\text { Raleigh } \\
\text { Wilmington }\end{array}$ & $86 / 02 / 25$ & $\begin{array}{l}\text { Clinton } \\
\text { Lewiston } \\
\text { Raleigh } \\
\text { Wilmington }\end{array}$ \\
\hline $86 / 02 / 06$ & $\begin{array}{l}\text { Clinton } \\
\text { Lewiston } \\
\text { Moorehead City } \\
\text { Raleigh } \\
\text { Wilmington }\end{array}$ & $86 / 02 / 26$ & $\begin{array}{l}\text { Clinton } \\
\text { Lewiston } \\
\text { Moorehead City } \\
\text { Raleigh } \\
\text { Wilmington }\end{array}$ \\
\hline $86 / 02 / 21$ & $\begin{array}{l}\text { Clinton } \\
\text { Lewiston } \\
\text { Raleigh } \\
\text { Wilmington }\end{array}$ & $86 / 03 / 01$ & $\begin{array}{l}\text { Moorehead City } \\
\text { Wilmington }\end{array}$ \\
\hline $86 / 02 / 24$ & $\begin{array}{l}\text { Clinton } \\
\text { Lewiston } \\
\text { Moorehead City } \\
\text { Raleigh } \\
\text { Wilmington }\end{array}$ & $86 / 03 / 03$ & $\begin{array}{l}\text { Moorehead City } \\
\text { Raleigh } \\
\text { Wilmington }\end{array}$ \\
\hline
\end{tabular}

(a) All sites were in North Carolina.

February 26 and March 3, providing continuous 4-hour resolution for trace element concentrations in background aerosol in two size ranges: $<2.5 \mu \mathrm{m}$, and 2.5 to $10 \mu \mathrm{m}$.
Aircraft. During January 15 to March 15. 1986, there were 13 periods in which the full GALE program was active (i.e., an Intensive Observing Period or IOP). During each IOP, airborne measurements were collected. Table 6 lists each IOP with a brief description of the dominant feature of the weather. IOPS 7, 8, and 11 encompassed (with one exception) the PRECP aircraft flights made during the period from February 21 to March 3.

The PNL. DC-3's flight times and dates are shown in Table 7. In addition to the precipitation, filter, and impactor sampling, listed in Table 7, continuous measurements were made with the instruments identified in Table 2.

Weather During PRECP-IV Intensive, February 21 to March 3, 1986

From February 21 to March 3, six cold fronts and one warm front passed through the study region. Most of the frontal precipitation fell as rain, but Raleigh did experience light snow on February 26 and 28 . Table 8 sumnarizes the weather activity during the frontal storm studies of PRECP-IV. 
TABLE 6. Intensive Observing Periods (IOPs)

\begin{tabular}{|c|c|c|c|c|}
\hline IOP 1 & $1 / 18 / 00 Z-1 / 20 / 21 Z$ & $65 \mathrm{~h}$ & $(2 \mathrm{~d}, 21 \mathrm{~h})$ & Upper-level cyclogenesis onshore plus coastal wave. \\
\hline IOP 2 & $1 / 23 / 12 Z-1 / 29 / 04 Z$ & $136 h$ & (5d,16h) & Nearshore cyclogenesis and cold air cyclogenesis. \\
\hline IOP 3 & $2 / 02 / 18 Z-2 / 04 / 23 Z$ & $53 \mathrm{~h}$ & $(2 d, 5 h)$ & Quasi-stationary front; New Jersey coastal front. \\
\hline IOP 4 & $2 / 06 / 07 Z-2 / 08 / 00 Z$ & 41h & $(1 d, 17 h)$ & Convective disturbance and quasi-stationary front. \\
\hline IOP 5 & $2 / 09 / 00 Z-2 / 13 / 23 Z$ & $119 \mathrm{~h}$ & $(4 d, 23 h)$ & $\begin{array}{l}\text { Multiple pulses, cyclogenesis far offshore, cold air outbreak, } \\
\text { "polar low." }\end{array}$ \\
\hline $10 P 6$ & $2 / 14 / 00 Z-2 / 15 / 17 Z$ & $41 \mathrm{~h}$ & (1d, 17h) & Wave and far offshore cyclogenesis. \\
\hline $10 P 7$ & $2 / 21 / 12 Z-2 / 22 / 06 Z$ & $18 h$ & & Wave passage through Virginia. \\
\hline IOP 8 & $2 / 22 / 17 Z-2 / 24 / 01 Z$ & $32 \mathrm{~h}$ & (1d,, $8 h)$ & Coastal cyclogenesis. \\
\hline IOP 9 & $2 / 24 / 18 Z-2 / 26 / 19 Z$ & $49 \mathrm{~h}$ & $(2 \mathrm{~d}, 1 \mathrm{~h})$ & Rapid cyclogenesis offshore. \\
\hline IOP 10 & $2 / 27 / 00 Z-2 / 28 / 12 Z$ & $36 \mathrm{~h}$ & $(\mathbf{1 d}, \mathbf{1 2 h})$ & Alberta Clipper and coastal cyclogenesis. \\
\hline IOP 11 & $2 / 28 / 21 Z-3 / 02 / 21 Z$ & $48 \mathrm{~h}$ & $(2 d, 0 h)$ & Modest cyclogenesis well offshore. \\
\hline IOP 12 & $3 / 06 / 17 Z-3 / 09 / 21 Z$ & $76 h$ & $(3 d, 4 h)$ & Anticyclone. \\
\hline IOP 13 & $3 / 11 / 17 Z-3 / 15 / 00 Z$ & $79 h$ & (3d,7h) & Coastal front followed by convectively active cyclogenesis. \\
\hline TOTAL & & $793 \mathrm{~h}$ & (33d,1h) & \\
\hline
\end{tabular}

TABLE 7. DC-3 Mission Summary for PRECP-IV

\begin{tabular}{|c|c|c|c|c|c|}
\hline Date & $\begin{array}{l}\text { Flight Time } \\
\text { (GMT) }\end{array}$ & $\begin{array}{l}\text { Altitude } \\
\text { (KFt MSL) }\end{array}$ & $\begin{array}{c}\text { Filter } \\
\text { Packs(a) }\end{array}$ & $\begin{array}{l}\text { Precipitation } \\
\text { Samples (rain) }\end{array}$ & Impactor \\
\hline $2-21$ & $1830-2200$ & $\begin{array}{l}3 \\
5 \\
4 \\
6\end{array}$ & $\begin{array}{l}2 T 1 D \\
1 T 1 D \\
1 T \\
2 T 1 D\end{array}$ & 6 & \#337 \\
\hline $2-22$ & $2350-0215$ & $\begin{array}{l}2 \\
3 \\
5\end{array}$ & $\begin{array}{l}1 T \\
1 T \\
2 T\end{array}$ & $\begin{array}{r}2 \\
10\end{array}$ & $\# 341$ \\
\hline $2-24$ & $2055-0035$ & $\begin{array}{l}2.5 \\
4 \\
3\end{array}$ & $\begin{array}{l}1 T \\
1 T\end{array}$ & $\begin{array}{r}14 \\
6\end{array}$ & H344 \\
\hline $2-26$ & $2100-0135$ & $\begin{array}{l}2.5 \\
4\end{array}$ & $\begin{array}{l}2 T 1 D \\
2 T 2 D\end{array}$ & 2 & *347 \\
\hline $2-27$ & $1820-2105$ & $\begin{array}{l}2-3 \\
2 \\
6-4 \\
4\end{array}$ & $\begin{array}{l}1 T 1 D \\
1 T \\
1 T 1 D \\
1 T 1 D\end{array}$ & $\begin{array}{l}2 \\
9\end{array}$ & $\# 350$ \\
\hline 3-01 & $1550-1815$ & $\begin{array}{l}2.5 \\
5.5\end{array}$ & $\begin{array}{l}1 \mathrm{~T} 1 \mathrm{D} . \\
1 \mathrm{~T} 1 \mathrm{D}\end{array}$ & . & $\# 353$ \\
\hline $3-03$ & $1540-1945$ & $\begin{array}{r}12 \\
6 \\
4 \\
3\end{array}$ & $\begin{array}{l}\text { IT 1D } \\
1 \mathrm{~T} 1 \mathrm{D} \\
\\
1 \mathrm{~T} 1 \mathrm{D}\end{array}$ & $\begin{array}{l}4 \\
6\end{array}$ & $\# 356$ \\
\hline
\end{tabular}

(a) T indicates triple filter pack - aerosol, $\mathrm{SO}_{2}, \mathrm{NNO}_{3} ; \mathrm{D}$ indicates double filter pack - aerosol, $\mathrm{NH}_{3}$. 
TABLE 8. Weather Summary February 21 to March 3, 1986

Date W_ Weather Summary

$2 / 20$ Foggy early to ove stratus by mid morning. Clear in afternoon. Southeast coast in warm air. A weak front Thur was to the west from KY to VA.

$2 / 21 \quad$ Ovc stratus much of the day with fog early. A cold front was to the west from a low in $W V$. The low Fri reformed east on the Appalachians by $18 \mathrm{Z}$ and the cold front passed Raleigh during the day.

2/22 Overcast with low clouds in the morning and overrunning clouds and occasional rain and drizzle in the Sat afternoon and evening in advance of a weak cold front that passed during the night.

$2 / 23$

Sun

$2 / 24$

Mon

Clear skies at Raleigh. Upper trough to the west.

Rapidly thickening high clouds in advance of a dry WF across TN-NC at 127. Rain in late afternoon and KF passed RDU in the evening. TRW near Fayetteville.

Mostly clear. Cold and windy. High pressure ridge to the west.

Thickening overrunning clouds ahead of a WF in western NC by $15 Z$. Light $S$ in the afternoon at RDU, changing to SP later. Amounts very light.

$2 / 27$

Complex spoke-like frontal system from a low over western NC. Ovc skies with embedded

Thur thunderstorms. Rain midday, sometimes moderate in intensity. KF passed RDU later in the day.

Weak upper trough moving over NC brought overcast skies and a little very light S. Moderate to severe icing in the clouds reported by aircraft.

Cloudy skies in the morning, clearing near noon. Cold. High pressure over NC.

Clear skies and a few high clouds as high pressure remained over the southeast states. Cold.

A weak WF passed RDU early in the morning accompanied by a light shower. RDU remained in the warm sector most of the day. A line of showers developed to the south of RDU by noon and produced intense radar echoes later. A dry KF approached RDU, but was hard to identify.

3/4 RDU had mostly low clouds and chilly N winds. A zone of convergence south of RDU produced some Tue thunderstorms along the SC coast, but precipitation onshore did not occur north of Charleston, SC.

3/5 Scattered cumulus and cool north winds all day. High pressure over NC. This was the last day of the Wed PRECP-IV field experiments.

Abbreviations: $R=$ Rain, $S=$ Snow, $S P=$ Snow pellets (soft hail), TRW = Thunderstorm, $R D U=$ Raleigh-Durham, $\mathrm{KF}=$ Cold Front, $\mathrm{WF}=$ Warm Front, $\mathrm{OVC}=$ Overcast

\section{Summary}

This program had many components. The program was structured to take advantage of all available opportunities to help achieve the stated goals.

Within the entire 60-day operational period of the GALE meteorological program, PRECP-IV/ GAPS was active in two modes. Airborne chemical sampling was carried out by PRECP-IV on the NCAR Electra, the NCAR Sabreliner, the NOAA P-3, and by the University of Washington on their C-131A. In the second mode, precipitation and filter sampling was performed on the surface by PRECP. Three surface networks were used to collect coordinated precipitation and aerometric samples. The rainband network was almost entirely dedicated to working with coordinated flights of the University of Washington's C-131A.

In an intensive period of study from February 21 to March 3, PNL's DC-3, BNL's Queen Air, and NOAA's King Air were deployed on PRECP-IV missions. The frontal and rainband networks operated in association with these missions. 
The full PRECP-IV data base will be assembled during FY-1987.

Acknowledgments

Substantial contributions to PRECP-IV were made by PNL personnel: G. W. Dennts, D. W. Glover, J. L. Gregory, R. V. Hannigan, and D. S. Sharp.
REFERENCES

Drexel University. 1986. Gale Field Program

Summary. Philadelphia, Pennsylvania.

MCAR. 1986. Genesis of Atlantic Lows

Experiment Operations Plan. National Center for Atmospheric Research, Boulder, Colorado. 



\section{- Soviet Accident Fallout Measurements}

Objectives of this study were:

To characterize the evolving chemical and physical properties of the released radionuclides,

To define the regional-scale to global-scale transport and dispersion of the released radionuclides,

To determine the dry-deposition velocities for the different radionuclides as a function of surface type and regional-to-global transport times, and

To measure the precipitation scavenging of the released radionuclides and their concentrations in cloud water and in air flowing through clouds on which the scavenging characteristics depend.

FIELD STUDIES OF THE ATMOSPHERIC PROCESSING OF RADIONUCLIDES RELEASED AT CHERNOBYL

W. G. N. Slinn, R. L. Brodzinski, K. M. Busness, M. T. Dana, W. E. Davis, C. E. Elderkin, W. K. Hensley, E. A. Lepel, A. C. D. Leslie, R. W. Perkins, D. E. Robertson, J. M. Thorp, and J. A. Young; (a) J. F. Boatman and L. R. Gunter; (b) R. R. Dickerson; (C) M. Kritz; (d) and A. Schanot (e)

Figure la shows the atmosphere's temperature structure at Kiev, U.S.S.R., near the time of the initial release of radioactivity from the damaged Chernobyl nuclear plant on April 26, 1986; Figure 1b shows the height of the 850-mb pressure surface and analyzed wind speeds. Because of the heat of the release and the lack of a strong temperature inversion below $10,000 \mathrm{ft}$ (see Figure 1a), it is likely that the released radioactivity was well mixed in the atmosphere, at least up to $10,000 \mathrm{ft}$ and possibly to higher altitudes. This good mixing both decreased the concentration of radioactivity local to the accident and increased the potential for the material's long-range atmospheric transport.

This report gives a summary description of the goals and execution of our field studies to characterize the radionuclides released from Chernobyl and to examine their longrange atmospheric transport and processing. For this report, we ask the reader to note the following three points:

(a) PNL authors.

(b) Air Quality Group, NDAA, Boulder, Colorado.

(c) Department of Meteorology, U of MD, College Park, Maryland.

(d) NASA, Ames, California.

(e) NCAR, Boulder, Colorado.
1. Starting on April 28, 1986, an intensive planning and preparation effort was mounted over a very short time intercept and characterize the Chernobyl plume on its arrival over the western U.S.

2. During the execution of these studies, we had very little firm information (beyond our own measurements and trajectory estimates) to confirm the location of the Chernobyl plume.

3. On May 20, 1986, the studies were terminated, after extensive airborne sampling of air, cloud water, precipitation, soil, and vegetation as the plume traversed the western and central U.S. and moved into Canada.

Because of the third point, derived from funding constraints, no data interpretations are reported here, though preliminary radiochemical analyses have been completed for the more-than-600 samples that were collected. In this report, we shall therefore outline the questions we identified and how we addressed them; in later reports, we will demonstrate our answers to these questions.

To conduct the studies described here, surface air was sampled at Richland, Hashington; vegetation and rain samples were collected from San Diego, California, to Juneau, Alaska, and from Seattle, Washington, to St. Cloud, Minnesota; and four aircraft used for meteorological research were additionally equipped with instrumentation to sample radioactivity: NASA's U-2, NCAR's Sabreliner, NOAA's King Airr, and PNL's DC-3. Aboard the latter three aircraft, not only filter samples but also "real-time" ganma-ray spectra were obtained. Aboard the $\mathrm{DC}-3$, equipment 
Kiev Sounding 86/04/26 00z

Comments

1. Local consequences would heve been far wores if the atmosphere had been more stable.

2. Upper portion of plume may heve embedded in near-isothermal layer at $-10,000^{\circ}$ or may have reached $>15,000^{\circ}$

3. "Potential-temperature tag" (viz, entropy) of plume $\sim 30^{\circ} \mathrm{C} \simeq 300^{\circ}$.

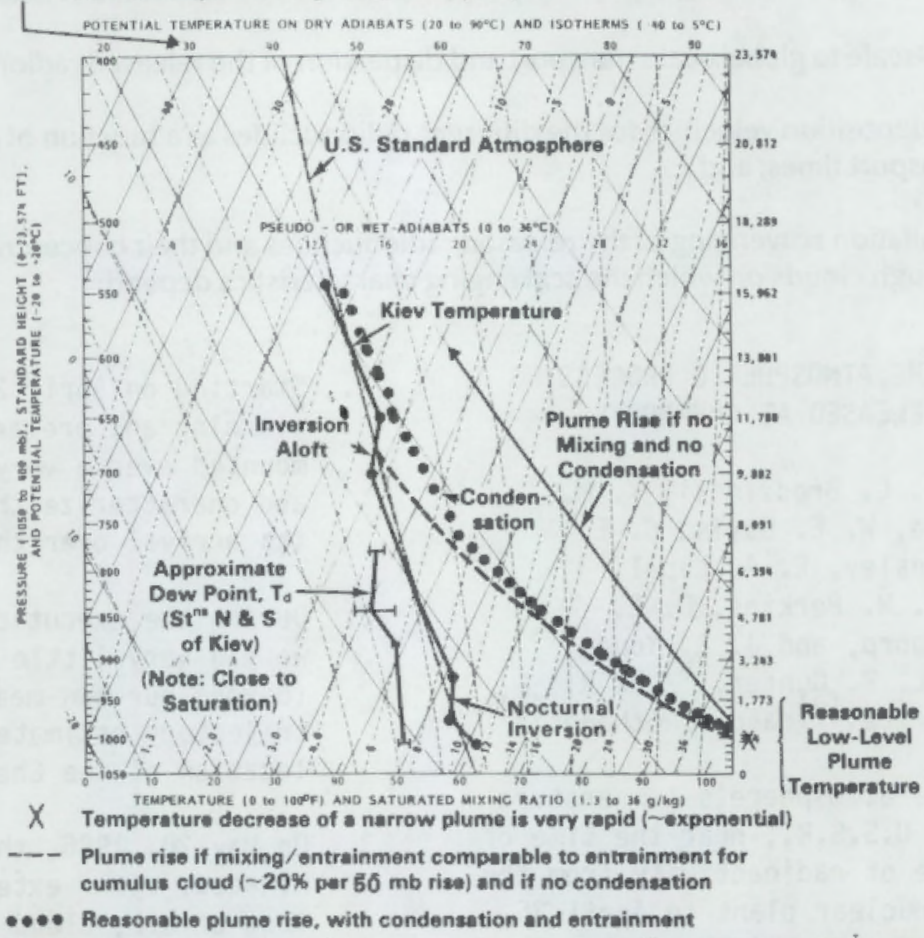

rise, with condensation and entrain

FIGURE 1a. Temperature and Approximate Dew-Point Temperature Above Kiev at 00 GMT on April 26, 1986. The dotted curve is a qualitative estimate of the expected plume rise; a thorough analysis could be performed using available plume-rise models and data for the heat release; observations of the plume rise are available.

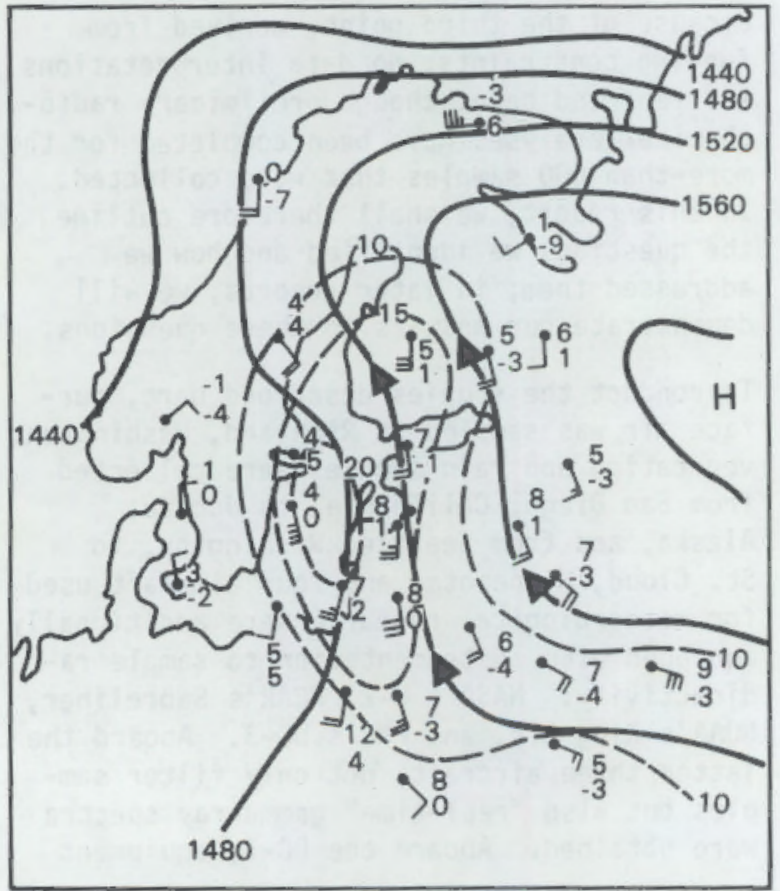

FIGURE 1b. Height $(\mathrm{m})$ of the $850-\mathrm{mb}$ Pressure Level at 00 GMT on April 26, 1986. The dashed lines are isopleths of wind speeds in $\mathrm{m} / \mathrm{s}$. The wind arrows for each station point in the direction of the wind; each full barb represents $10 \mathrm{kts}$ wind speed and each half barb, 5 kts. Digits to the right of each station are temperature and dewpoint temperature in ${ }^{\circ} \mathrm{C}$. The analysis suggests direct flow of the first release of radioactivity toward Scandinavia. From Finnish Center for Radiation and Nuclear Safety (1986). 
was also installed to characterize the gaseous and particulate forms of the radionuclides, and the usual complement of equipment for air-pollution studies (including cloud water, rain, and snow collectors, and instruments for measuring meteorological variables) was onboard (since we had just returned from the PRECP-IV field studies) and utilized. A hint of the scope of this effort can be seen from the number of authors and their affiliations, and from the list of acknowledgments; a hint of the intensity of our efforts can be gained from the fact that the instruments were assembled, mounted, operated, and testflown during the first weekend after the release occurred, two days after we had been asked by DOE to conduct this program.

\section{Properties of the Released Radionuclides}

Atmospheric processing of radionuclides depends on their chemical and physical properties. This statement is abundantly clear for wet- and dry-deposition processes, but it is also true for coagulation and chemical reactions (e.g., the possible photodissociation of methyl iodide $\left(\mathrm{CH}_{3} \mathrm{I}\right)$ and subsequent attachment of radioactive isotopes of iodine to atmospheric aerosol particles). Therefore, as a first goal, we assigned ourselves this important task: to define the physical and chemical characteristics of the intercepted radionuclides.

Appropriate equipment (cascade impactors, filter packs, charcoal traps, etc.) was installed at the surface-level station in Richland and aboard PNL's DC-3 aircraft to address the following questions and subquestions:

1. What was the chemical form of the iodine?

a. Did the proportion of organic versus inorganic iodine shift with transport time?

b. Was there any remaining $\mathrm{CH}_{3} \mathrm{I}$, or had it all photodissociated on a much shorter time scale?

c. What was the distribution of iodine with particle size?

2. What was the particle size distribution for each radionuclide? a. For each radionuclide, does its particle size distribution depend on the temperature of the release?

b. Does the particle size distribution shift with transit time?

3. With the graphite fire, what were the properties of the released radioactive carbon? An answer to this question is needed if the radioactive carbon is to be used to address other important issues, such as the following:

a. Relevant to the nuclear-winter issue:

what is the atmospheric residence time of particulate, elemental carbon?

b. Relevant to the atmospheric greenhouse effect of fossil-fuel $\mathrm{CO}_{2}$, what is the environmental fate of ${ }^{14} \mathrm{CO}_{2}$ ?

4. What noble gases were released?

The last question is especially relevant for plans to use the released radioactivity to study long-time-scale atmospheric processes, such as troposphere-to-stratosphere exchange, inter-hemispheric mixing, and air-to-sea transfer processes.

As yet, we do not know how successfully we answered these questions, but we did collect relevant data at Richland (cf. Table 1 and Figure 2) and on flights from Juneau to Reno, Nevada, and from Seattle to Duluth, Minnesota. When funding permits completion of the data reduction and interpretation, the results will be reported in the scientific literature.

\section{Regional-Scale Atmospheric Processing}

The scientific values of sampling the radioactivity in Europe were clear: to determine the near-source physical and chemical properties of the radioactivity, its wet and dry deposition, and its atmospheric transport and diffusion. However, we decided to perform only limited surface sampling in Europe, in part because of logistical difficulties, in part because we expected that our European colleagues would mount substantial monitoring programs, and in part because our efforts to 
TABLE 1. Radionuclide Concentrations in Air at Richland, Washington(a)

\begin{tabular}{|c|c|c|c|c|c|c|c|c|c|c|c|c|c|c|c|}
\hline \multicolumn{2}{|c|}{ On } & \multicolumn{2}{|c|}{ Off } & \multirow[b]{2}{*}{${ }^{95} \mathrm{Nb}$} & \multicolumn{11}{|c|}{$\mathrm{fCl} \cdot \mathrm{m}^{-3}$} \\
\hline Date & Time & Date & Time & & ${ }^{100} \mathrm{Ru}$ & ${ }^{106} \mathrm{Ru}$ & ${ }^{10 \mathrm{~m}_{\mathrm{Ag}}}$ & ${ }^{131} 1$ & ${ }^{132} \mathrm{Te}$ & ${ }^{134} \mathrm{Cs}$ & ${ }^{136} \mathrm{Cs}$ & ${ }^{13 y} \mathrm{Cs}$ & ${ }^{140} \mathrm{Ba}$ & ${ }^{111} \mathrm{Ce}$ & ${ }^{14} \mathrm{Ce}$ \\
\hline $5 / 6$ & 1600 & $5 / 7$ & 0700 & & & & & & & 5 & & & & & \\
\hline $5 / 7$ & 0712 & $5 / 7$ & 1722 & & & & & 8 & & & & & & & \\
\hline $5 / 7$ & 1732 & $5 / 8$ & 0740 & & & & & 40 & & & & & & & \\
\hline $5 / 8$ & 0750 & $5 / 8$ & 1517 & & & & & 57 & & & & & & & \\
\hline $5 / 8$ & 1527 & $5 / 8$ & 2043 & & 20 & & & 165 & 20 & & & 28 & & & \\
\hline $5 / 8$ & 2057 & $5 / 9$ & 0037 & & 23 & & & 198 & 15 & & & 27 & & & \\
\hline $5 / 9$ & 0037 & $5 / 9$ & 0721 & & 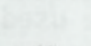 & & & 178 & 6 & & & 42 & & & \\
\hline $5 / 9$ & 0723 & $5 / 9$ & 1154 & & 61 & & & 369 & 42 & & & 67 & & & \\
\hline $5 / 9$ & 1201 & $5 / 9$ & 1555 & & 255 & & & 1380 & 152 & & & 167 & & & \\
\hline $5 / 9$ & 1605 & $5 / 9$ & 1805 & 3.8 & 781 & 180 & & 3760 & 451 & 254 & & 478 & 219 & 22 & 7.6 \\
\hline $5 / 9$ & 1818 & $5 / 9$ & 2000 & & 362 & 85 & & 1480 & 198 & 114 & & 212 & 96 & 6.8 & 4.7 \\
\hline $5 / 9$ & 2007 & $5 / 9$ & 2201 & & 367 & & & 1900 & 287 & & & 555 & & & 5.8 \\
\hline $5 / 9$ & 2210 & $5 / 10$ & 0730 & & 336 & & & 1320 & 251 & & & 520 & & & \\
\hline $5 / 10$ & 0739 & $5 / 10$ & 1157 & & 224 & & & 1230 & 186 & & & 438 & & & \\
\hline $5 / 10$ & 1207 & $5 / 10$ & 1549 & 2.6 & 295 & 70 & & 1830 & 234 & 315 & & 579 & 117 & & 5.8 \\
\hline $5 / 10$ & 1557 & $5 / 10$ & 1957 & & 249 & & & 1590 & 186 & & & 491 & & & \\
\hline $5 / 10$ & 2009 & $5 / 10$ & 2339 & & 97 & & & 438 & 60 & & & 143 & & & \\
\hline $5 / 10$ & 2348 & $5 / 11$ & 0748 & & 38 & & & 133 & 22 & & & 61 & & & \\
\hline $5 / 11$ & 0757 & $5 / 11$ & 1151 & & 21 & & & 187 & 15 & & & 40 & & & \\
\hline $5 / 11$ & 1159 & $5 / 11$ & 1559 & & 34 & & & 252 & 19 & & & 58 & & & \\
\hline $5 / 11$ & 1609 & $5 / 12$ & 0751 & & 38 & & & 120 & 11 & & & 30 & & & \\
\hline $5 / 12$ & 0801 & $5 / 12$ & 1320 & & 247 & & & 807 & 76 & & & 154 & & & \\
\hline $5 / 12$ & 1328 & $5 / 12$ & 1934 & 1.6 & 567 & 139 & & 1890 & 176 & 206 & & 392 & 60 & & 3.2 \\
\hline $5 / 12$ & 1946 & $5 / 12$ & 2346 & & 286 & & & 671 & 86 & & & 197 & & & \\
\hline $5 / 12$ & 2359 & $5 / 13$ & 0653 & & 111 & & & 189 & 27 & & & 72 & & & \\
\hline $5 / 13$ & 0703 & $5 / 13$ & 1503 & & 37 & & & 190 & 10 & & & 36 & & & \\
\hline $5 / 13$ & 1518 & $5 / 13$ & 2303 & & 4.9 & & & 53 & & & & 7.1 & & & \\
\hline $5 / 13$ & 2319 & $5 / 14$ & 0754 & & 5.1 & & & 28 & & & & 4.3 & & & \\
\hline $5 / 14$ & 0801 & $5 / 14$ & 1955 & & 32 & & & 178 & 6.8 & & & 34 & & & \\
\hline $5 / 14$ & 2005 & $5 / 15$ & 0005 & & 49 & & & 261 & 9.7 & & & 47 & & & \\
\hline $5 / 15$ & 0015 & $5 / 15$ & 0709 & & 46 & & & 215 & 8.3 & & & 52 & & & \\
\hline $5 / 15$ & 0719 & $5 / 15$ & 1855 & & 58 & & & 255 & 10 & & & 56 & & & \\
\hline $5 / 15$ & 1905 & $5 / 16$ & 0722 & & 101 & & & 299 & 16 & & & 98 & & & \\
\hline $5 / 16$ & 0732 & $5 / 16$ & 2120 & & 268 & & & 865 & 38 & & & 195 & & & \\
\hline $5 / 16$ & 2129 & $5 / 17$ & 0120 & & 375 & & & 1010 & 50 & & & 273 & & & \\
\hline $5 / 17$ & 0129 & $5 / 17$ & 0529 & & 344 & & & 626 & 42 & & & 245 & & & \\
\hline $5 / 17$ & 0536 & $5 / 17$ & 0938 & & 340 & & & 672 & 41 & & & 250 & & & \\
\hline $5 / 17$ & 0946 & $5 / 17$ & 1558 & & 354 & & & 807 & 45 & & & 247 & & & \\
\hline $5 / 17$ & 1607 & $5 / 18$ & 0832 & & & - & & 464 & 32 & & & & & & \\
\hline $5 / 18$ & 0842 & $5 / 18$ & 1818 & & 148 & & & 209 & 12 & & & 92 & & & \\
\hline $5 / 18$ & 1827 & $5 / 19$ & 0757 & & & & & 100 & 8.7 & & & & & & \\
\hline $5 / 19$ & 0808 & $5 / 19$ & 1941 & & & & & 89 & & & & & & & \\
\hline $5 / 19$ & 1950 & $5 / 20$ & 0738 & & & & & 130 & & & & & & & \\
\hline
\end{tabular}

(a) This includes only the ${ }^{131}$ I content of the air which is associated with particulates and was collected on particle filters. The true atmospheric concentration is approximately twice this value and includes both inorganic and organic gaseous forms of iodine. 


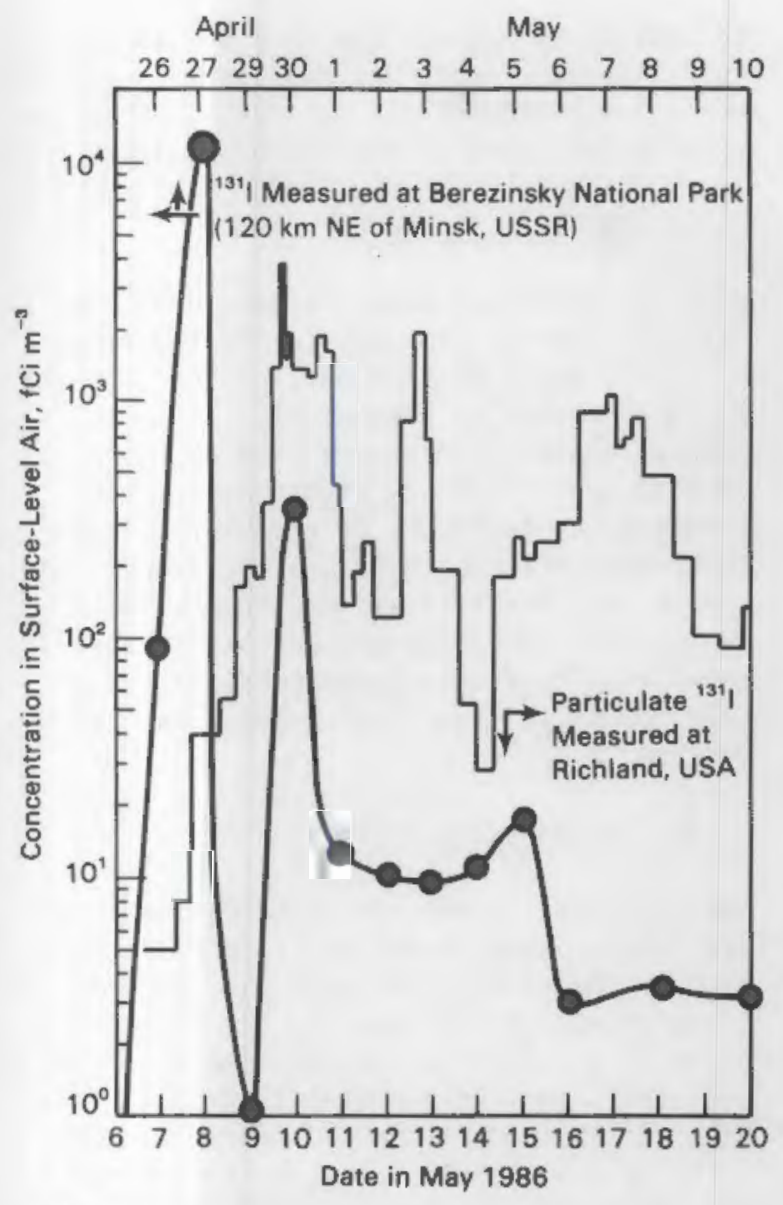

FIGURE 2. Air Concentrations of ${ }^{431} I$ Measured at Berezinski National Park, U.S.S.R., and at Richland, Washington, USA. Notice the three orders-of-magnitude difference in the units for concentrations and the approximately 12-day time lag for detection of the Chernobyl radiation at Richland.

sample in Europe would dilute our unique opportunities to sample the radioactivity at the global scale, after it had traveled across the U.S.S.R., Asia, the Pacific Ocean, and North America. Now, at the time of this writing, our decision appears to have been intelligent, since we now have available to us both extensive data from Europe and unique data from North America.

When we are able to proceed with the data analysis, it seems clear that much will be learned from the available European data. The simplest use of the data for concentrations of the radioactivity in air, in precipitation, and on surfaces) would be to determine wet- and dry-deposition velocities. The next simplest use would be to try to assess the evolutions in the chemical and physical properties of the radioactivity. In addi tion, it would be valuable to learn, from Soviet scientists who were aboard their sampling aircraft, additional information about the observed plume-rise and the efficacy of the cloud-seeding activities they applied. But the most significant use of the European data will be to test the many numerical models (both simple and complex) for atmospheric dynamics and for pollutant transport, diffusion, wet and dry deposition, and chemical and physical transformations; such tests are critically important if an appreciation of the adequacy of available U.S. models is to be gained; Figure $3 a$ illustrates trajectory calculations made with U.S.S.R. models.

\section{Global-Scale Atmospheric Transport and Diffusion}

Never has there been and we all hope never will there again be such an opportunity to test global-scale models of atmospheric transport and diffusion of reactive species released at relatively low levels in the troposphere. It is true that there is a data point in the literature resulting from sampling, by the British Meteorological office, for the long-range transport and diffusion of the discharge from the Mt. St. Helens' eruption, but the material was generally unreactive and was injected into the upper troposphere and stratosphere. Also, there is a data point in the literature resulting from European sampling in the troposphere of the radioactivity from one of the early bomb tests in Nevada, but again the material was injected high into troposphere, and it is only a single data point (other bomb tests put their radioactivity mostly in the stratosphere). In contrast, the Chernobyl release was ideal (solely from a meteorological viewpoint) for testing our abilities to model the long-range transport of air pollution, since the many species released possessed a host of different chemical and physical properties, the release was at low levels, and an impressively large sampling program was conducted. When adequate funding is made available, important new results will follow from thorough analysis of the data during the next decade. 


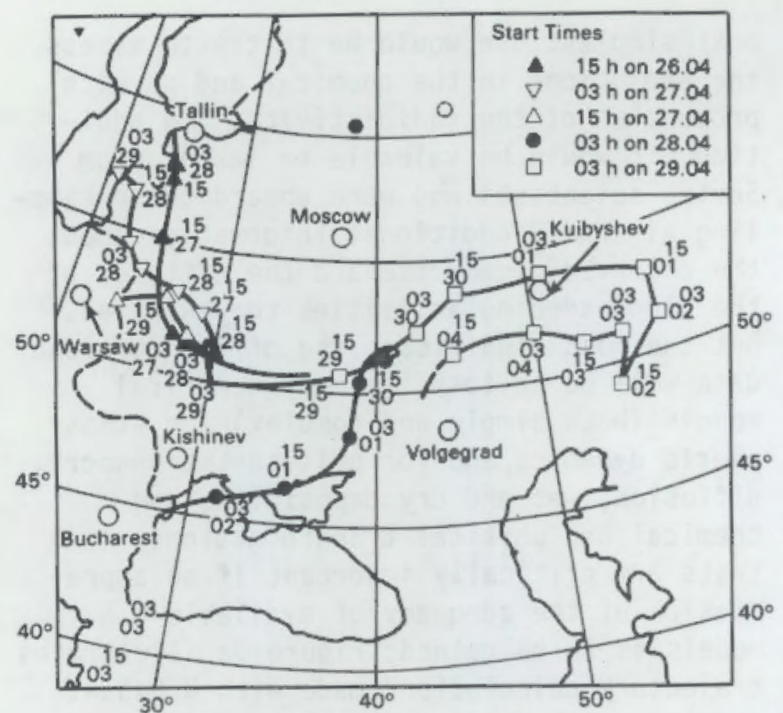

FIGURE 3a. Trajectories at $0.7 \mathrm{~km}$ Altitude, Starting from the Chernobyl Reactor at the Times Indicated and Continuing Until the Trajectories Left the U.S.S.R. From U.S.S.R. State Committee of the Utilization of Atomic Energy (1986).

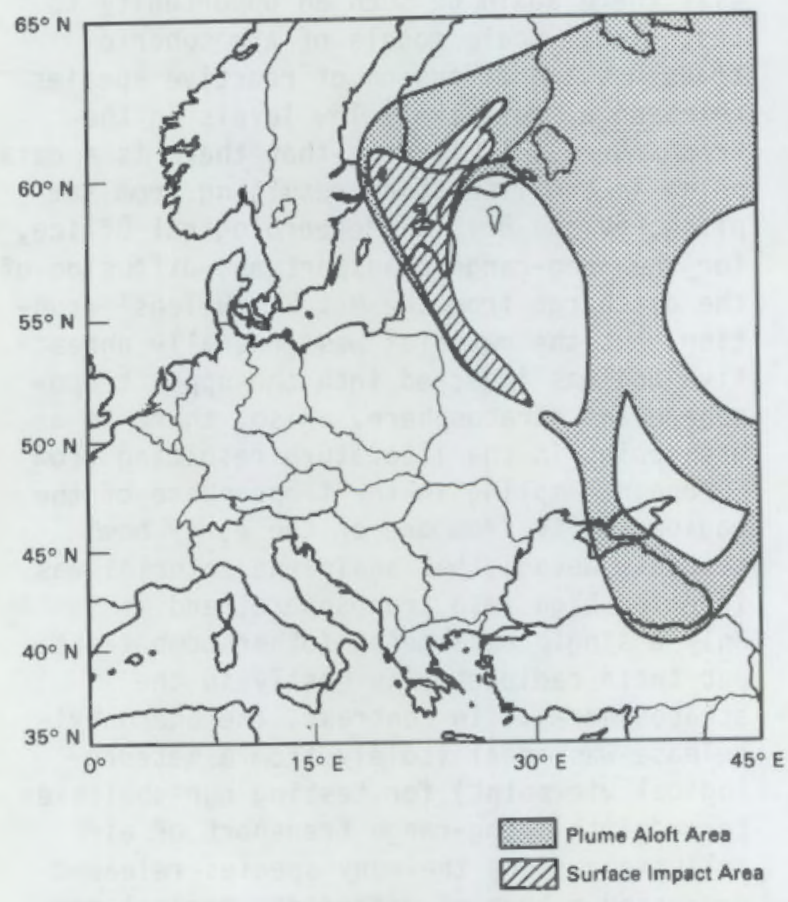

FIGURE 3b. Preliminary Estimate of Vertical Redistribution of the Chernobyl Plume After It Traveled Through a Frontal Storm Near Southern Finland.
We considered and will be able to address four important questions dealing with globalscale processing of air pollution. These are briefly described in the following list.

\section{Vertical Transport}

From the available data, it should be possible to address the question of the amount of rapid, vertical transport of the radioactivity caused by deep storms. It seems likely that frontal storms over southern Finland and convective storms over Japan promoted the transport of the radioactivity to higher altitudes, where with greater wind speeds, the material was transported more rapidly and with less diminution. Figure $3 \mathrm{~b}$ shows results from a preliminary analysis of this "plume lofting" that appears to have occurred over Finland.

\section{Horizontal Transport}

The data will almost certainly be the best available to test global-scale models of horizontal transport. The need for improvements in these models was clear in the operational phase of our studies, in which we used predictions from four global-scale models to help position our aircraft. Thus, our own calculations suggested that we concentrate our low-level flights of the $D C-3$ and $k i n g$ Air in Washington, but the data now available support our decision to use our calculations only as a rough guide: the data show that the first intrusion of the Chernobyl plume into North American air occurred between Cold Bay, Alaska (Aleutian Islands) and at-leastas-far-south as the California-Oregon border.

Figure 4 gives details of our "operationalphase" trajectory estimates. From Chernobyl to Japan, trajectories were calculated for two levels: 850- and 700-mb. Aircraft sitings over Japan showed the debris to be located from the 700 - to the $500-\mathrm{mb}$ levels. Based on these measurements, a new series of trajectories was initiated. For each level, two trajectories were computed, with a crosswind distance between them of about $0.5 \mathrm{t}$ (with $t$ the elapsed travel time); this distance was used to estimate the spread caused by atmospheric diffusion. 


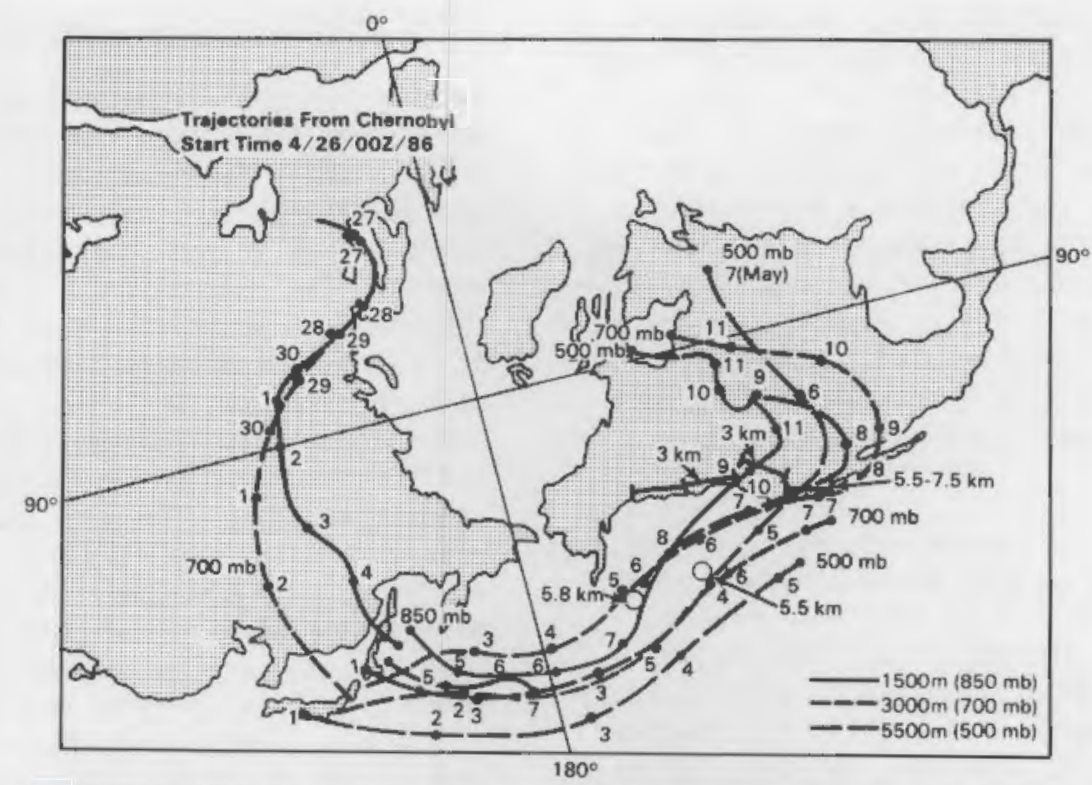

FIGURE 4. Operational-Phase (i.e., "real-time") Estimates of the Global-Scale Trajectories of the Release from Chernobyl. The 700 and $850-\mathrm{mb}$ trajectories were calculated from estimates of geostrophic and gradient winds, based on the NMC hemispheric analysis, updated every 12 hours. Predicted trajectories were produced from the 24 and 36 -hour prognostic charts. The map is a polar view.

Two sightings were reported off the West Coast, at altitudes of 5.5 and $5.8 \mathrm{~km}$, at the locations indicated by the open circles in Figure 4 . Since the second siting was not consistent with earlier sitings (because flights for these were constrained), a new 500-mb trajectory was initiated. Positive sitings by aircraft are indicated at altitudes of $3 \mathrm{~km}$ to the north (DC-3 and King Air) and at 5.5 and $7.7 \mathrm{~km}$ to the south (NASA's U-2). As shown, the 500-mb trajectories were predicted to skim the West Coast and finally enter over the continent in California and northern Mexico. After swinging south, these trajectories were predicted to move northward through the central U.S. and into Canada (Hudson Bay and Labrador).

Apparently the 850-mb trajectory exited Asia too far north to be measured by the flights from Japan. This trajectory was expanded into two trajectories (again to estimate the influence of diffusion), but the more southern of the two was dropped because the trajectory ended in an area of low-speed flow over the Pacific. The more northern of the two was forecasted to intercept the west coast of North America over Washington state on May 9.

\section{Horizontal Diffusion}

The relatively uniform horizontal distribution mentioned in point 2 (above) is consistent with substantial horizontal diffusion. We have the raw data needed to define the associated diffusivity quite accurately (from our flights on May 9 from Juneau to Reno). The result for the diffusivity will extend the results in the literature to an order-of-magnitude-larger travel time than heretofore has been available.

However, even from the operational phase of our studies, an important point was abundantly clear. From loops of satellite photographs of cloud cover during the sampling period, it was clear that as the radioactivity approached the west coast of North America, the plume's width was dictated simply by the size (approximately 2,000 km) of the anticycionic eddy in which the 
radioactivity was imbedded. It therefore seems that the use of standard eddy-diffusion formulations, with diffusivities (or associated plume widths) increasing with a simple power of travel time, are quite inappropriate for estimating the width of a particular plume in a particular meteorological setting. At best, horizontal diffusion theory may give an acceptable statistical description for a large number of observations; however, for a particular case, the specific eddies governing the plume's "diffusion" must be identified.

Nevertheless, our preliminary results (see Figure 5) show roughly where our data point will appear relative to existing results. Figure 5 shows the major extension in scale that our studies will provide: approximately an order of magnitude in travel time beyond previous results. However, the location of our data point must be viewed as preliminary, until we complete the data analysis phase of this project.

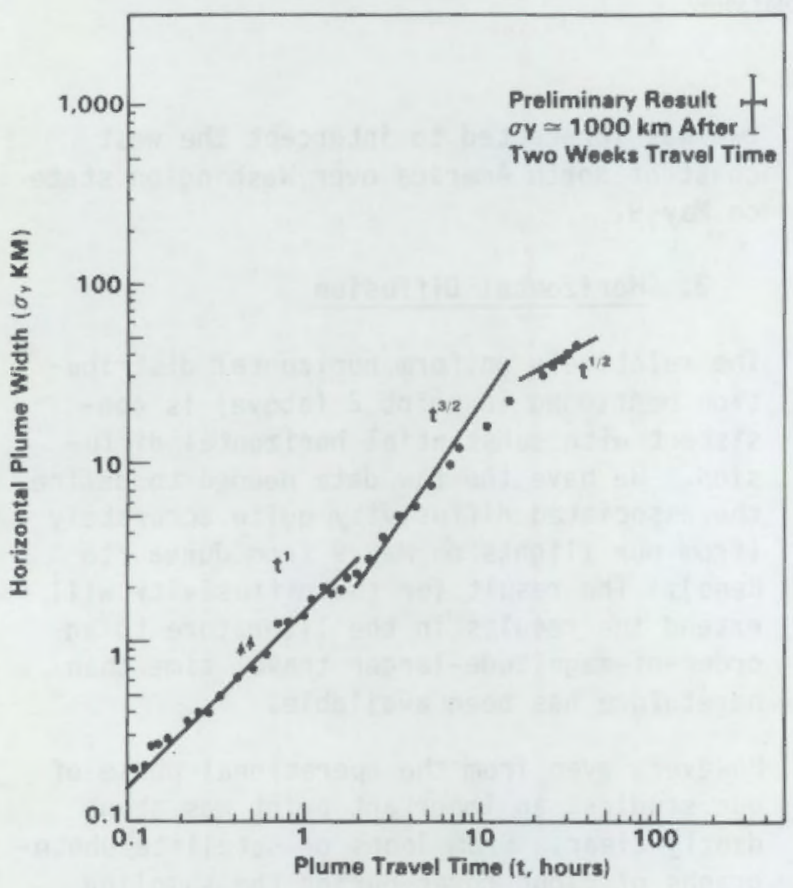

FIGURE 5. Representative Data from the Scientific Literature for Plume Width as a Function of Travel Time with a Qualitative Indication of One of the Data Points That Will Be Available from our Chernobyl Studies. Adapted from Gifford (1984) and Carras and Williams (1981).

\section{Atmospheric Residence Times}

Perhaps the most important question we addressed, a question for which partial answers are al ready available (even from the operational phase of our program) is one so obvious that it can be easily overlooked: what are the atmospheric residence times of the released materials? The obvious answer is that the tropospheric residence times, even for reactive pollution (reactive chemically and as cloud-condensation nuclei), a re sufficiently long to result in transport around the globe. We note, not incidentally, that this unequivocal experimental result conflicts with some predictions that were made at the time of the Chernobyl accident. When funding permits, we will perform thorough evaluations for the residence times of the many species detected. However, already we expect that the e-fold time for the tagged, tropospheric submicron particles is two to three weeks, which is consistent with some theoretical predictions but much longer than others.

\section{Dry-Deposition Studies}

The atmospheric residence time of most of the radioactivity released from Chernobyl (an exception is the noble gases) is dictated by rates of wet and dry deposition. (For noble gases, the dominant removal process is simply their radioactive decay.) These wet and dry removal processes were the focus of the majority of our studies. In this section, the execution of our dry-deposition studies will be described; the next section will describe our wet-deposition (and storm-processing) studies.

In our dry-deposition studies, we sought to define the dry deposition of the radioactivity after it had traveled approximately $10,000 \mathrm{~km}$ in the troposphere; we intend later to compare the results with the drydeposition rates found for Europe, after the material had traveled less than about $1,000 \mathrm{~km}$. If this study is successful, as it appears to have been, we will be able to provide the first firm data to assess a current plausible (but untested) theory about drydeposition velocities. (The dry-deposition velocity, $v_{d}$, is the dry flux divided by the 
local air concentration; therefore, $v_{d}$ is expected to be independent from the air concentration for most of the released radioactivity.) The untested theory predicts that the dry-deposition velocities for the radioactivity would decrease with increasing travel time, not because of differing air concentrations, but resulting from the evolution of the radioactivity itself (e.g., the particle size distribution would evolve to forms less susceptible to dry deposition, as the more rapidly material is deposited first). We additionally set ourseives the tasks to try to define the dependence of the dry deposition on different surface types.

To execute these dry-deposition studies, we obtained air, grass, and evergreen-needle samples for radiochemical analyses at the sites shown in Figure 6 . In addition, we performed a rain-throughfall study at an agricultural research station at Lamberton, Minnesota. The method of the throughfall study is to obtain rain samples in front of and at a series of locations within and under a forest canopy: the enhanced concentration of the radioactivity in rain collected beneath the canopy can then be related to the amount of radioactivity dry-deposited to the forest (during the period since the last rainfall). When the data can be analyzed, we will be able to determine if these studies were successful; for now, we at least know that the necessary ingredients for success were there, including the radioactivity, defined dry periods, and in the case of the throughfall study, rain.

\section{Wet-Deposition and Storm-Processing Studies}

Storm tapping, precipitation scavenging, and storm venting studies were performed in the manner outlined below.

\section{Storm Tapping}

The concept studied is that deep storms can penetrate into polluted, upper-level air, and the droplets and/or ice crystals can acquire some of the radioactivity from the overriding air and subsequently deposit the radioactivity in precipitation. As seen in Figure 4, we had reasons to expect that on May 5-6, 1986, only the leading and southern edge of the plume had reached the U.S. mainland. Our plan (suggested in Figure 7) was as follows. The overriding polluted air was relatively stable above $20,000 \mathrm{ft}$. Clouds developed beneath this stable layer and grew to at least 22,000 ft, and therefore, had the

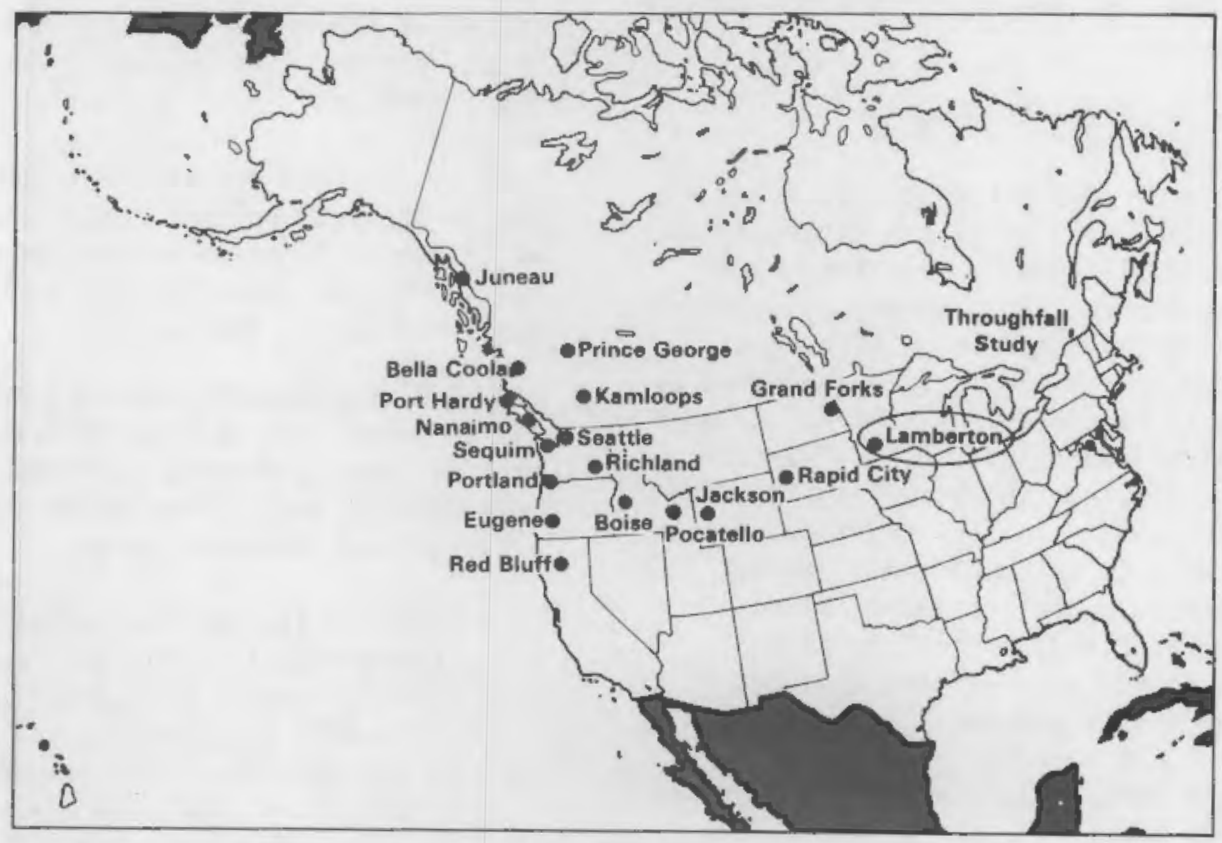

FIGURE 6. Locations at Which We Collected Samples for Analysis of Dry-Deposited Radioactivity and from Which Dry-Deposition Velocities Can Be Calculated. 
Q1. Storm Tapping

5.6 May 1986

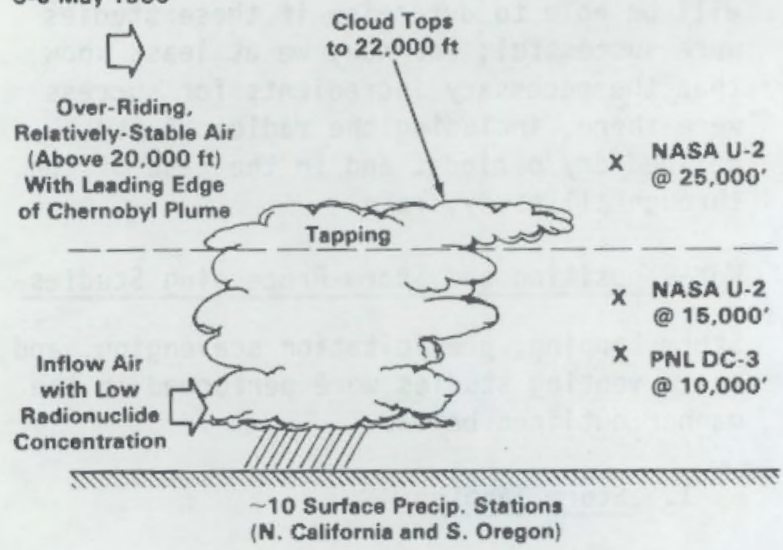

FIGURE 7. A Schematic of Our "Storm-Tapping" Studies, Conducted with PNL's DC-3 and NASA's U-2 Aircraft.

potential for tapping the radioactivity in the overriding air. For these studies, we arranged for a NASA U-2 aircraft, stationed at Ames, California, to obtain filter samples of the radioactivity at 25,000 and $15,000 \mathrm{ft}$. Meanwhile, PNL's DC-3 obtained filter samples and gamma-ray spectra at 10,000 ft. Approximately 10 precipitation samples were also obtained. As funding permits, we will be able to see if storm-tapping did occur; if it did, we should have the necessary data to evaluate its magnitude.

\section{Precipitation Scavenging}

Three facets of precipitation scavenging are expected to be revealed by the data collected during May 10-11, 1986, on our flights of NOAA's King Air and PNL's DC-3 that extended from Juneau to Reno and from Seattle to Denver. During this period, as suggested in the sketch in Figure 8 , the King Air sampled pre- and post-frontal air. The $\mathrm{OC}-3 \mathrm{col}-$ lected approximately $15 \mathrm{cloud-ice}$ and cloudliquid-water samples on its leg from Seattle to Reno. We also collected rain samples at the surface at Seattle and Richland, Washington; Portland, Oregon; Boise and Pocatello, Idaho; and Jackson, Wyoming. As two examples of the data (reported by others), the EPA reported that the rain at Boise during this storm carried the greatest

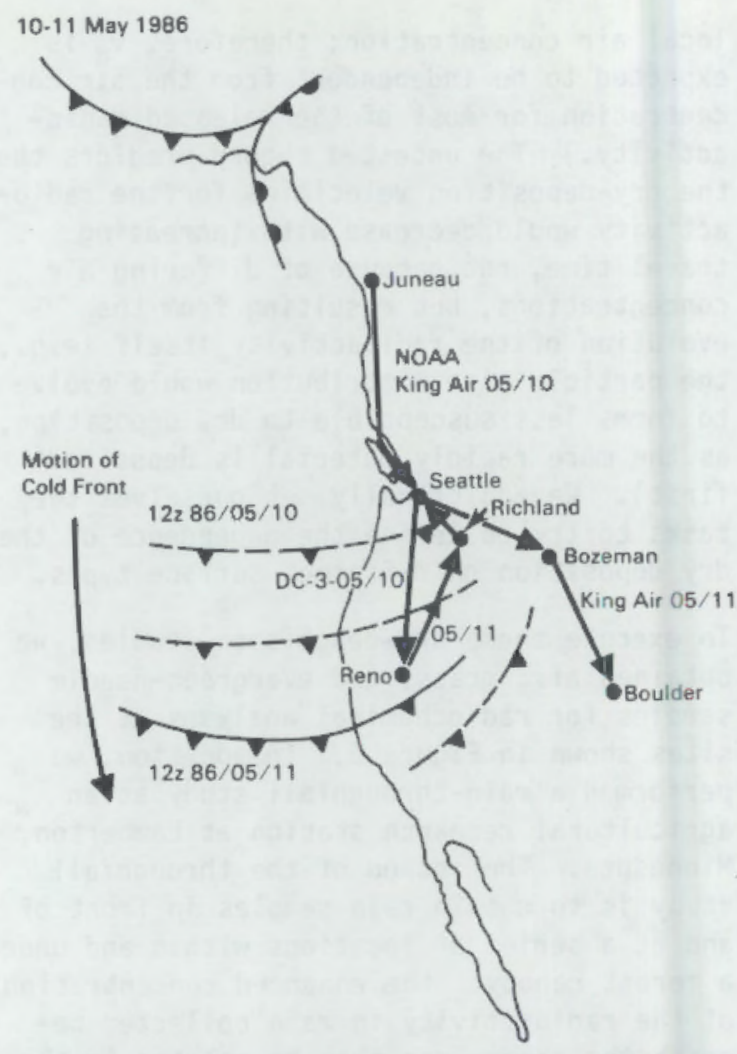

FIGURE 8. Frontal Location and Flight Paths for Our Precipitation-Scavenging Studies Conducted During May 10-11, 1986, with PNL's DC-3 and NOAA's King Air Aircraft.

burden of Chernobyl radioactivity seen at Boise, and the EML reparted that the wet deposition of ${ }^{131} \mathrm{I},{ }^{137} \mathrm{Cs},{ }^{134} \mathrm{Cs}$, and ${ }^{103} \mathrm{Ru}$, on May 11 at Forks, Washington, were 4.82, $0.76,0.25,0.41 \mathrm{mCi} / \mathrm{km}^{2}$ (all numbers to within about 10 percent coefficient-ofvariation). Other data have been reported by the EML for Beaverton and Medford, Oregon, and for Rexburg, Idaho.

For this measurement campaign, there is a little doubt that we have obtained data relevant to three phenomena important in the mathematical description of the precipitation scavenging of radionuclides.

1. From the (to our knowledge) first-ofits-kind data on the in-cloud distribution of radioactivity, we expect to be able to determine the partitioning of the radioactivity between cloud liquid-water, ice, and air. 
2. From the measured concentrations in the air flowing into the storm and in the precipitation from the storm, we will be able for the first time (as far as we know) to calculate improved scavenging ratios for the radionuclides (improved in the sense of being based on air concentrations entering the storm, rather than on concentrations measured in surface-level air).

3. From the data for rain concentrations at flight altitudes and at the surface, we may be able to determine the relative contributions to the surface-level rainborne radioactivity from in-cloud versus below-cloud scavenging.

All three of these data sets have potentials to yield important new information, and we are therefore quite eager to proceed with the data analysis.

\section{Storm Venting}

The final set of studies that we conducted dealt with the vertical venting (or transport) of low-level radioactivity, deep into the troposphere and possibly into the lower stratosphere, in the outflow of intense storms. As was mentioned earlier, this may have happened over Finland soon after the material's release. In the first of our storm-venting studies in the U.S. and Canada, a second flight of NASA's U-2 obtained samples at 45,000 and $55,000 \mathrm{ft}$ over northern California, to determine if any of the radioactivity had already reached the stratosphere. In the second storm-venting study, whose design is sketched in Figure 9, PNL's DC-3 sampled (and detected) the radioactivity beneath a cold front in North Dakota and collected precipitation beneath the storm (to supplement the surface-rain samples that we collected at sites in Minnesota and that were made available to us from NADP at many Midwest sites). The $D C-3$ also obtained air samples of the radioactivity at several altitudes ahead of the cold front. Simultaneous with the $D C-3$ flights, NCAR's Sabreliner sampled the radioactivity at altitudes between 25,000 and $35,000 \mathrm{ft}$, in the outflow of the storm. Although ${ }^{131}$ I was successfully detected by gamma-ray spectrometers both beneath the front (in the $\mathrm{DC}-3$ ) and in the outflow (in the Sabreliner, both over Manitoba and over Minnesota), the filter (and precipitation) data have not yet been

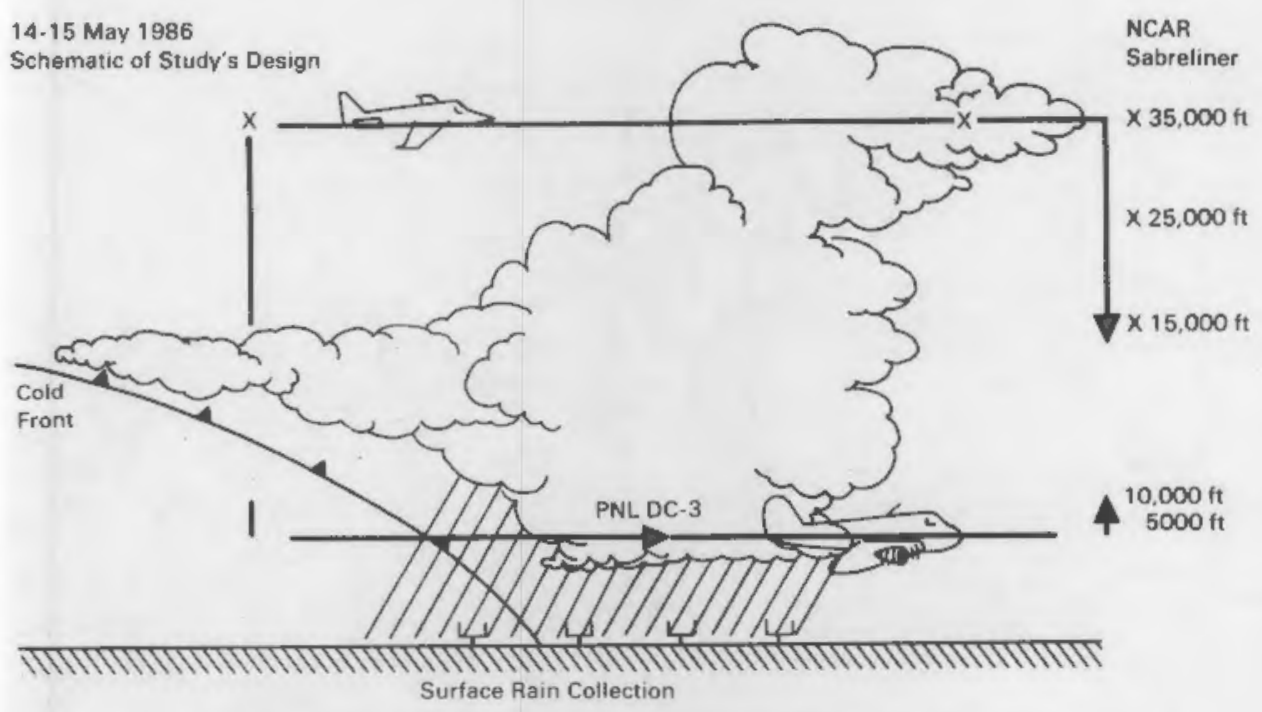

Sabreliner: Sample CO inonreactive), $\mathrm{NO}_{x}$ (produced in storm by lightning), trace metals, and radionuclides, in anvil and in surrounding air (at 35,000, 25,000 and $15,000 \mathrm{ftl}$

DC-3: Sample same species at low levels and collect precipitation and cloud water during storm penetration.

FIGURE 9. Schematic of Our "Storm-Venting" Studies, Conducted May 14 through 15, 1986, with PNL's DC-3 and NCAR's Sabreliner Aircraft. 
reduced. However, it seems quite clear that this storm-venting study was successful.

Summary and Conclusion

With only a few days for preparation, we conducted a series of studies on topics that were known to be important for improving the mathematical modeling of the fate of radioactivity released to the atmosphere. Early indications are that all our studies were successful, at least in the sense that we appeared to be at the right place, at the right time, and we executed the right procedures. We will know more, and report on what we have learned, when a thorough data analysis becomes possible.

We recognize that, at best, this report is just an "appetizer." Additional tastes of the flavor of this operational phase of our program might be obtained from Figures 10 and 11: Figure 10 shows radar echos, frontal position, and flight paths taken by PNL's OC-3 and NCAR's Sabreliner, during our stormventing studies (as expected, the storm intensified during the flights); Figure 11 is indicative of the fact that we had all our other instruments aboard the $\mathrm{DC}-3$ also functioning, throughout all our flights, so that we will be able to compare the atmospheric processing of the Chernobyl radionuclides to the processing of other species, e.g., those of interest in the acid-rain issue. In summary, we have tried to give the reader a taste of flavorful food for thought; the banquet, when we can dig into the data, has not yet begun.

\section{Acknowledgments}

Significant assistance to these studies were provided by B. G. Christensen, G. W. Dennis, J. D. Forsythe, D. W. Glover, J. L. Gregory, R. V. Hannigan, J. C. Lau1, G. L. Laws, J. H. Reeves, D. S. Sharp, C. W. Thomas, and N. M.

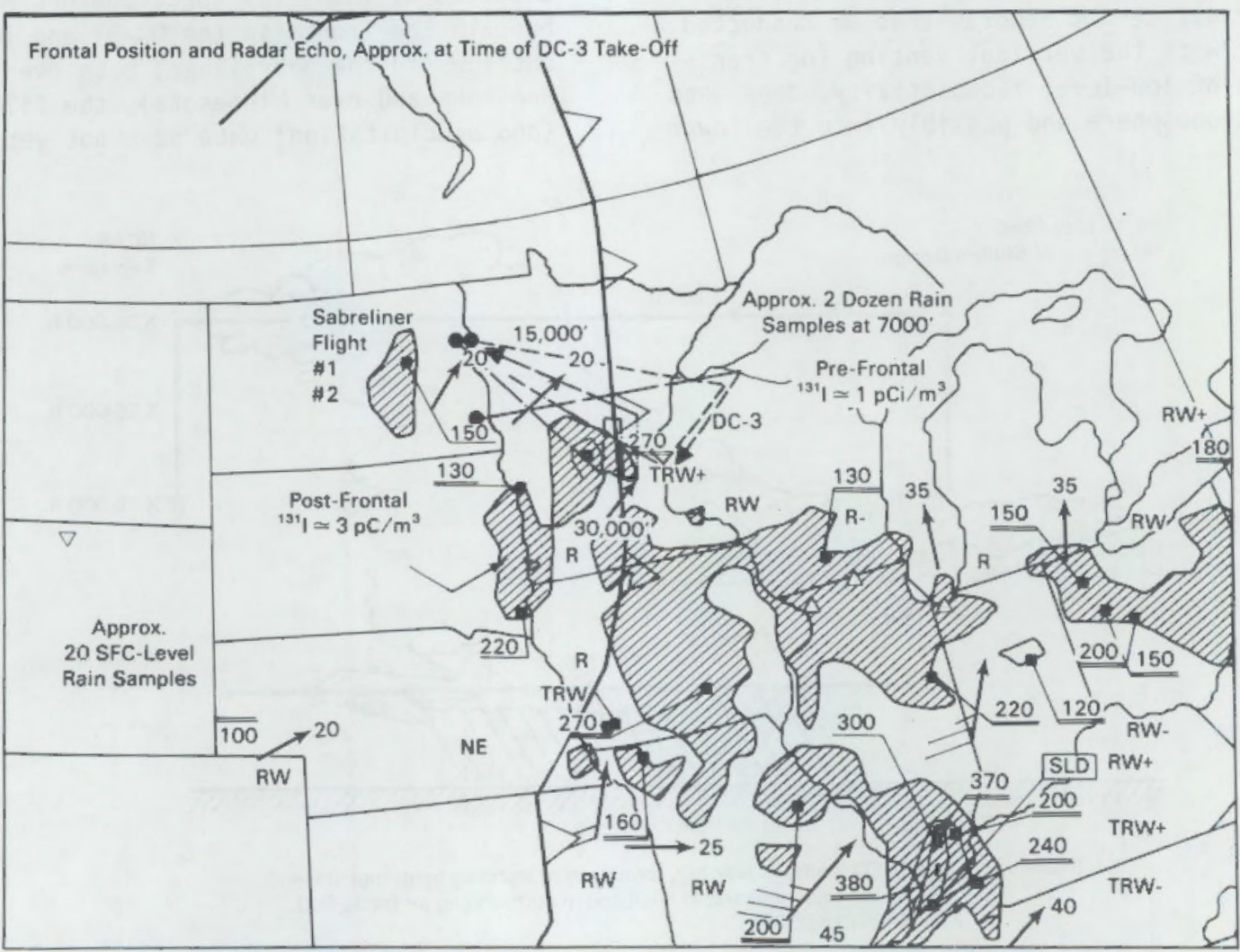

FIGURE 10. Radar Echos, Frontal Location, and Flight Paths for Our "Storm-Venting" Studies on May $15,1986 . R=$ rain, $R W=$ rain shower, $T R W=$ thundershower, $\pm=$ growing or decaying, underlined numbers give cloud tops in hundreds of feet, numbers associated with arrows give cell motion in knots; feathered arrows give surface-level wind speed (full barb $=10 \mathrm{kts}$; half barb $=5 \mathrm{kts}$ ). 

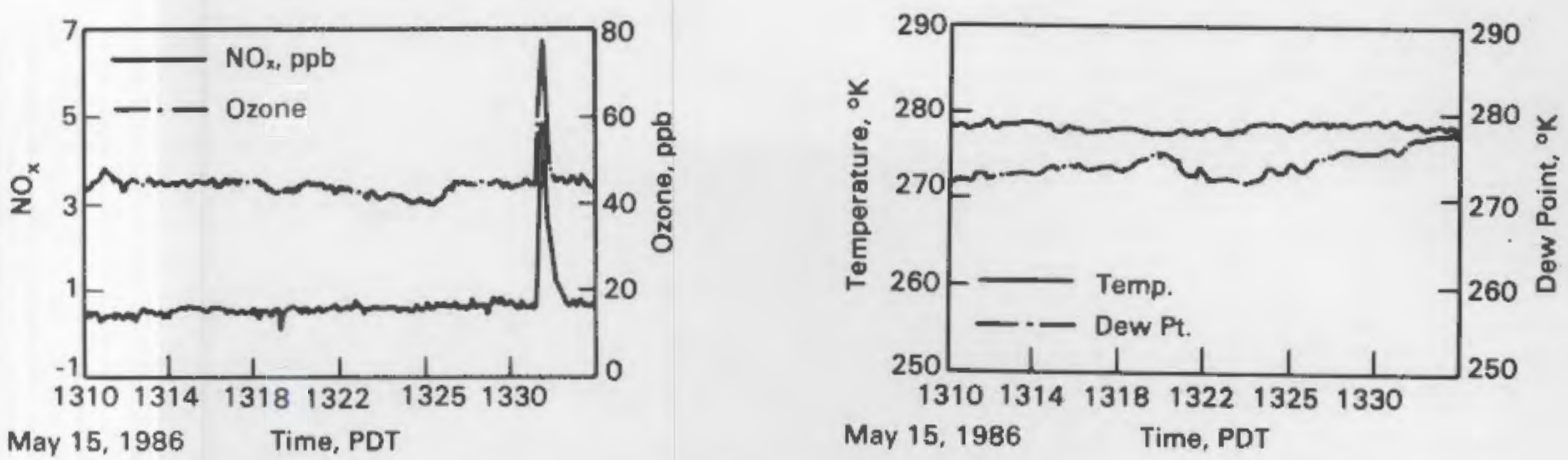

FIGURE 11. Temperature, Dewpoint, and Concentrations of $\mathrm{NO}_{\mathrm{x}}$ and $\mathrm{O}_{3}$ at $7,000 \mathrm{ft}$, as the DC-3 Passed Through the Front Shown in Figure B; the Peaks in the $\mathrm{NO}_{x}$ and $\mathrm{O}_{3}$ Correspond to an Intense Updraft from the Mixed Layer, Also Carrying the Radioactivity Aloft, Subsequently Sampled by NCAR's Sabreliner.

Thomas. We sincerely thank W. R. Barchet, G. J. Stensland and operators at many NADP sites, plus L. Adams, L. W. Chase, J. Dana, L. Flake, C. L. Thorp, and S. B. Verma, for collecting precipitation samples for us. Special thanks go from the senior author to Peter Daum of BNL, George Isaac of the AES, Dick Perkins of PNL, and Dave Slade of DOE for help that was sustaining. We heartily thank P. E. Merilees, Director General of the Atmospheric Research Directorate, AES, for prompt and courteous permission to allow us to sample over Canada. We also thank Alvin Trivelpiece, Director of the Office of Energy Research, and C. P. Delisi, Director of the DOE Office of Heaith and Environmental Research, for seeing the scientific opportunities and encouraging us to pursue them.

\section{REFERENCES}

Carras, J. N., and D. J. Williams. 1981. "The Long-Range Dispersion of a Plume from an Isolated Point Source." Atmos. Environ. 15:2205-2217.
Finnish Center for Radiation and Nuclear Safety. 1986. Interim Report on Fallout Situation in Finland from 26 April to 4 May 1986. STUK-B-VALV0-44, ISSN 0781-2868.

Gifford, F. A. 1984. The Observed Rate of Tropospheric Diffusion. LA-10181-MS, Los Alamos National Laboratory, Los Alamos, New Mexico.

U.S.S.R. State Committee of the Utilization of Atomic Energy. 1986. "The Accident at the Chernobyl Nuclear Power Plant and Its Consequences." Information for the IAEA Experts' Meeting, August 25-29, 1986, Vienna. Part II, Annexes 1-6, International Atomic Energy Agency, Vienna, Austria. 



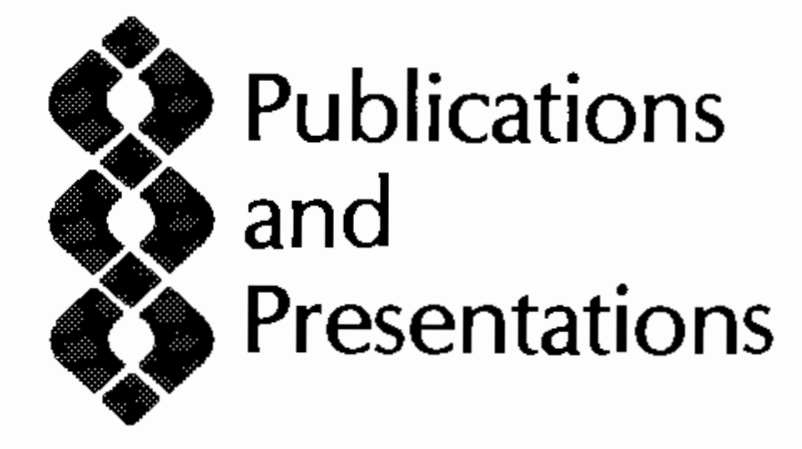




\section{PUBLICATIONS}

Alkezweeny, A. J. 1986. A Study of the Formation and Transport of Acidic Species by Non-Precipitating Cumulus Clouds During VENTEX-84. PNL-6007, Pacific Northwest Laboratory, Richland, Washington.

Alkezweeny, A. J., G. L. Laws and W. Jones, 1986. "Aircraft and Ground Measurements of Ammonia in Kentucky." Atmos. Environ., 20:357-360.

Alkezweeny, A. J., K. M. Busness and D. W. Doppenaal. 1985. "Contribution of NonPrecipitating Clouds to Acid Deposition." In Proceedings of Fourth Joint Conference on Applications of Air Pollution Meteorology, Ainerican Meteorological Society," Boston, Massachusetts.

Bader, D. C., T. B. Mckee, and G. J. Tripoli. 1987. "Mesoscale Boundary Layer Evolution Dver Complex Terrain. Part 1. Numerical Simulation of the Diurnal Cycle." Accepted for publication in J. Atmos. Sci..,

Bader, 0. C., and C. D. Whiteman. 1986. "Model Simulation of Plume Dispersion in a Narrow Valley After Sunrise." In Proceedings of the Fifth Joint Conference on Applications of Air Pollution Meteorology with APCA, pp. 254-257, American Meteorological Society, Boston, Massachusetts.

Publisher Ballinger, M. Y. 1985. "Aerosols Generated from Spills of High Viscosity Liqwids." In Abstracts of the American Associatian for Aerosol Research Annual Meeting.

Ballinger, M. Y., S. L. Sutter and J. Mishima. 1986. "Source-Term Development for Evaluation of Emergency Preparedness Needs for Nonreactor Facilities." Health Physics, 50:399-403.

Berkowitz, C. M., B. C. Scott, F. M. Vukovich and C. J. Walcek. 1986. "Design and Preliminary Results of a Precipitation of Scavenging Module." In Proceedings of the Fifth Joint Conference on Applications of Air Pollution, pp. 107-109, American Meteorological Society, Boston, Massachusetts.

Berkowitz, C. M., and R. C. Easter. 1986. Interin liser's Guide to the RADM Scavenging
Module (RSM) Version 1.0. PNL-6024, Pacific Northwest Laboratory, Richland, jwashington.

Chapman, E. G. 1986. "Evidence for S(IV) Compounds other than Dissolved $\mathrm{SO}_{2}$ in Precipitation." Geophys. Res. Letters, 13(13):1411-1414.

Chapman, E. G., D. J. Luecken, M. T. Dana, R. C. Easter, J. M. Thorp, J. M. Hales and N. S. Laulainen. 1986 (in press). "InterStom Comparisons from the OSCAR High Density Network Experiment." Atmos. Environ.

Chapman, E. G., and D. S. Sklarew. 1986. "Introduction of Formate and Acetate Ions into Precipitation: Assessment of Possible Pathways." In Symposium on Acid Rain: 1. Sources \& Atmospheric Processes. Ed. R. W. Johnson, American Chemical Society, Washington, D.C.

Chapman, E. G., and D. S. Sklarew, 1986 (in press). "Organic-Inorganic Ion Relationships in North American Precipitation." In Proceedings of the Symposium on the Chemistry of Acid Rain.

Ching, J. K. S., and A. J. Alkezweeny. 1986 (in press). "Tracer Study of Vertical Exchange by Cumulus clouds." J.Clim. Appl. Meteor.

Dana, M. T., and W. G. N. Slinn. 1987. "Deposition Statistics from the MAP3S Network: Episodes and dry Periods." Submitted to Atmos. Environ.

Davis, W. F., and C. S. Glantz. 1985. "A Comparisan of a Multi-Layer Regional Scale Acid Rain Assessment Model (MLRAPT) with a Single-Layer Assessment Model, RAPT." Water, Air and Soil Pollut., 30:857-366.

Dickerson, R. R., G. J. Huffman, W. T. Luke, L. J. Nunnerinacker, K. E. Pickering, A. C. D. Leslie, C. G. Lindsey, W. G. N. Slinn, T. J. Kelly, P. H. Daum, A. C. Delany, J. P. Greenberg, P. R. Zimmerman, J. F. Boatman, J. D. Ray and D. H. Stedman. 1987.

"Thunderstorms: An Important Mechanism in the Transport of Air Pollutants." Science, 235: 460-465. 
Doran, J. C., and S.-E. Gryming. 1986. "Wind and Temperature Structure Over a Landwater-Land Area." Accepted for publication in J. Clim. Appl. Meteor.

Glantz, C. S., M. Y. Ballinger and E. G. Chapman. 1986. An Inventory of Current Environmental Monitoring Projects in the U.S. - Canadian Transboundary Region. PNL -5880 , Pacific Northwest Laboratory, Richland, Washington.

Glantz, C. S., and J. V. Ransdell. 1986. Preliminary Examination of the Impacts of Repository Site Characterization Activities and Facility Construction and Operation Activities on Hanford Air Quality. PNL-5687, Pacific Northwest Laboratory, Richland, washington.

Hales, J. M. 1986 (in press). "A Generalized Multidimensional Model for Precipitation Scavenging and Atmospheric Chemistry." Atmos. Environ.

Hales, J. M. 1985 (in press). "Parameterization of Removal Mechanisms." AMS Monograph. American Meteorological Society, Boston, Massachusetts.

Hales, J. M. 1986. "The Mathematical Characterization of Precipitation Scavenging and Precipitation Chemistry." Handbook of Environmental Chemistry, Volume 4. 0. Hutzinger, ed. Springer-Verlag, New York, p. 149-252.

Horst, T. W., and J. G. Doran. 1985. "A Turbulent Kinetic Energy Budget in Nocturnal Slope Flow." Preprints, Seventh Symposium on Turbulence and Diffusion. November 12-15, 1985, American Meteorological Association, Boston, Massachusetts.

Morst, T. W., and J. C. Doran. 1986. "Nocturnal Drainage Flow on Simple Slopes." Boundary Layer Meteor., 34:263-296.

Horst, T. W., and J. C. Doran. 1986. "The Turbulence Structure of Nocturnal slope Flow." Accepted for publication in J. Atmos. Sci.

Luecken, D. J., and J. M. Hales. 1986. "The Effect of Precipitation on the Vertical Profiles of Atmospheric Ammonia: A Modeling Investigation." Atmos. Environn., 20(12): 2381-2388.
Mishima, J., J. L. Kenoyer, J. M. Selby and E. J. Vallario. 1986. "Consideration in Workplace Sampler Placement." In Abstracts of the 17th Fine Particle Society Meeting.

0rgill, M. M., and R. I. Schreck. 1985. "An Overview of the ASCOT Hulti-Laboratory Field Experiments in Relation to Drainage Winds and Ambient Flow." Bull. Amer. Meteor. Soc., 66(10): 1263-1277.

Orgill, M. M., J. M. Thorp, and R. Coulter. 1985. "Interaction of Sub-Mesoscale Flows in Complex Terrain During Nocturnal Drainage Conditions." In Abstracts of the 7th Conference on Turbuience and Diffusion. pp. 244247, American Meteorological Society, Boston, Massachusetts.

Penne11, W. T. 1986. "Chairman's Report: Workshop on Model Evaluation Protocols." Summary of Model Evaluation Protocol Workshop, February 11-13, 1986, Raleigh, North Carolina.

Scherpelz, R. I., T. J. Bander, G. F. Athey and J. V. Ransde11. 1986. "The MESORAD Dose Assessment Model." In Proceedings of the American Nuclear Society Topical Meeting Radiological Accidents: Perspectives and Emergency Preparedness, American Nuclear Society. La Grange Park, Illinois.

Schwartz, M. N., D. J. Hoitink, 0. P. Gifford, D. J. Newland, P. J. Perrault, E. R. Preston, G. N. Reinecke. 1986. "Extreme and Persistent Temperature Anomalies at Hanford, Washington, During 1985." In Proceedings of the First Conference on Human Consequences of 1985's Climate, American Meteorological Society, Boston, Massachusetts.

slinn, W. G. N. 1987 (in press). "Concentration Statistics for Dispersive Media." Tellus-B.

Slinn, W. F. N. 1987 (in press). "A Simple Model of Junge's Relationship Between Concentration Fluctuations and Residence Times." Tellus-B.

Thorp, d. M. 1986. "Mesoscale Stom and Dry Period Parameters from Hourly Precipitation Data." Atmos. Environ., 20:1683-1689.

Thorp, J. M., and M. M. Orgill, 1986. "A "Waterfall' of Air." Weatherwise 39:319-322. 
Vergeiner, I., E. Dreiseit 1 , and C. D. Whiteman. 1986 (in press). "Dynamics of Katabatic Winds in Colorado's Brush Creek Valley." J. Atmos. Sci.

Whiteman, C. D. 1986 (in press). "Temperature Inversion Buildup in Colorado's Eagle Valley." Met. and Atmos. Phys.
Whiteman, C. D., and K. J. Allwine. 1986. "Extraterrestrial Solar Radiation on Inclined Surfaces." Environ. Software. 1(3): 164-169.

Whiteman, C. D., and S. Barr. 1986.

"Atmospheric Mass Transport by Along-Valley Wind System in a Deep Colorado Valley." J. Clim. Appl. Meteor. 25:1205-1212. 



\section{PRESENTATIONS}

Bader, D. C., and C. D. Whiteman. 1986. "Model Simulation of Plume Dispersion in a Narrow Valley After Sunrise." Paper presented at the Fifth Joint Conference on Applications of Air Pollution Meteorology with APCA, November 18-21, 1986, Chapel Hill, North Caraitina.

Barchet, W. R. 1986. "An Interim Assessment: Acidic Deposition and Air Quality." Paper presented at the National Acid Precipitation Assessment Program Annual Meeting, June 12, 1986, Greenbelt, Maryland.

Berkowitz, C. M., B. C. Scott, F. M. Vukovich and C. J. Walcek. 1986. "Design and Preliminary Results of a Precipitation Scavenging Module." Paper presented at the Fifth Joint: Conference on Applications of Air Pollution Meteorology with APCA, November 18-21, 1986, Chapel Hill, North Carolina.

Chapman, E. G., and D. J. Luecken. 1986. "Field Intensives in Acid Precipitation Research: The OSCAR Experiment." Paper presented at the Specialty Conference on Acid Precipitation, April 8,1986 , Seattle, Washington.

Chapman, E. G., and D. S. Sklarew. 1986. "Organic-Inorganic Ion Relationships in North American Precipitation." Paper presented at the Symposium on the Chemistry of Acid Rain, April 13-18, 1986, New York, New York.

Dana, M. T. 1985. "Deposition Episode Statistics from MAP3S and APN Network Data." Paper presented at the Annual Technical Committee, National Atmospheric Deposition Program, October 7-11, 1985, Ft. Collins, Colorado.

Nair, S. K., L. K. Peters and A. J. Alkezweeny. 1986. "Simulation of the Formation and Physical, Chemical and Transport Processes Involved in Convective, NonPrecipitating Clouds." Presented at the Air Pollution Control Association Specialty Conference on the Meteorology of Acidic Deposition, March 17-20, 1986, Albany, New York.
Orgill, M. M., K. J. Allwine, R. N. Lee, J. M. Thorp and R. I. Schreck. 1986. "The Role of Local Winds and Thermal Stability in Transport and Diffusion Within a Narrow Valley." Paper presented at the Seventh World Clean Air Congress and Exhibition, August 2529, Sydney, NSW, Australia.

Orgill, M. M., J. M. Thorp and R. Coulter. 1985. "Interaction of Sub-Mesoscale Flows in Complex Terrain During Nocturnal Orainage Conditions." Paper presented at the Seventh Conference on Turbulence and Diffusion, November 12-15, 1985, Boutder, Colorado.

Owczarski, P. C., M. Y. Ballinger, J. Mishima and J. E. Ayer. 1986. "Radiological Source Tem Estimation Methods." Paper presented at the American Nuclear Society Topical MeetingRadiological Accidents: Perspectives and Emergency Preparedness Meeting, September 15, 1986, Bethesda, Maryland.

Owczarski, P. C., and W. K. Winegardner. 1986. "Capture of Iodine in Pressurized Nater Reactor Ice Condensers." Paper presented at the American Chemical Society Annual Meeting, September 11, 1986, Anaheim, California.

Owczarski, P. C., and W. K. Winegardner. 1985. "Validation of SPARC, a Suppression Pool Aerosol Capture Model." Paper presented at the International atomic Energy Agency International Symposium on Source Term Evaluation for Accident Conditions, 0ctober 28November 1, 1985, Colunbus, Ohio.

Payton, D. L., and D. J. Luecken. 1986. "Modeling Precipitation Scavenging from Plumes: A Case Study from the ASARCO Smelter Shutdown Experiment." Presented at the Pacific Northwest International Section - Air Pollution Control Association Annual Meeting, November 20, 1986, Eugene, Oregon.

Pennell, w. T. 1986. "Evaluating Acid Deposition Models." Paper presented to the Washington State University Acid Rain Research Consortium, March 20, 1986, Pullman, Washington. 
Scherpelz, R. I., G. F. Athey, T. J. Bander and J. V. Ramsde11. 1986. "The MESORAD Dose Assessment Mode?." Paper presented at the American Nuclear Society Topical MeetingRadiological Accidents: Perspectives and Emergency Preparedness, September 15-17, 1986, Bethesda, Maryland.

Schwartz, M. N., O. J. Hoitink, 0. P. Gifford, D. J. Newland, P. J. Perrault, E. R. Preston, G. N. Reinecke. 1986.

"Extreme and Persistent Temperature Anomalies at Hanford, Washington, During 1985." Paper presented at the First Conferene on Human Consequences of 1985's Climate, August 6-7, 1986, Asheville, North Carolina.

Slinn, W. G. N. 1986. "Atmosphere-Surface Exchange: Research Needs." Presented at the NAPAP Dry Deposition Workshop, March 25-27, 1986, Harpers Ferry, West Virginia.
Slinn, W. G. N. 1986. "Deposition of Atmospheric Pollution." Invited lecture prsented at the AMS Advanced Study Institute on Chemical and Meteorological Aspects of Atmospheric Source-Receptor Relationships, October 21-24, 1986, Oak Ridge, Tennessee.

Slinn, W. G. N. 1986. "Future DOE Atmospheric Cleansing Research." Presented to the Subcomittee on Atmospheric Research of the Federal Coordination Council for Science, Engineering, and Technology, December 11, 1986, Washington, 0.C. 
Author Index 


\section{AUTHOR INDEX}

\author{
Allwine, K.J.; 9 \\ Bader, D.C.; 3 \\ Boatman, J.F.; 55 \\ Brodzinski, R.L.; 55 \\ Busness, K.M.; 19, 31, 44, 55 \\ Dana, M.T.; 19, 44, 55 \\ Davis, W.E.; 31, 55 \\ Dickerson, R.R.; 55 \\ Doran, J.C.; 13, 15 \\ Easter, R.C.; 19 \\ Elderkin, C.E.; 55 \\ Gunter, L.R.; 55 \\ Hensley, W.K.; 55 \\ Horst, T.W.; 13
}

\author{
Hubbe, J.M.; 15 \\ Kritz, M.; 55 \\ Lepel, E.A;; 55 \\ Leslie, A.C.D.; 19, 44, 55 \\ Lindsey, C.G.; 19, 31 \\ Luecken, D.J.; 31 \\ Perkins, R.W.; 55 \\ Robertson, D.E.; 55 \\ Schanot, A.; 55 \\ Slinn, W.G.N.; 19, 31, 44, 55 \\ Thorp, J.M.; 31, 44, 55 \\ Whiteman, C.D.; 3, 9, 11 \\ Young, J.A.; 55
}





$$
8
$$




\section{DISTRIBUTION}

\author{
No, of \\ Copies \\ OFFSITE \\ 30 DOE Technical Information \\ Center
}

G. E. Adams, Director Medical Research Council Radiobiology Unit.

Chilton, Didcot

OxOn, OX11 ORD

ENGLAND

R. F. Alexander

ORPBR, NL

Nuclear Regulatory

Commission

washington, DC 20545

F.. L. Alpen

Donner Laboratory

University of California

Berkeley, CA $947 ? 0$ D. C. Aumann
Institut für Physikalische
Chemie

Der Iniversität Bonn

Abt. Nuk learchemie

Wegielerstrabe 12

5300 Bonn 1

FËIJERAL REPUBLIC

DF GERMANY

1. A, Auxier

IT/Radialogical Sciences Laboratory

1550 Bear Creek Road

Box 549

Oak Ridge, TN 37831

F. Badgley

13749 4lst street, N.F.

Seattle, WA 98125

R. ‥ Baker

827) Ivy League Lane

Rockville, MD 20850

R. M. Baltzo

Radiological Safety Division

University of washington

Seat:le, UA 98105
No. of

Copies

R. W. Barber

EH-133, GTN

Department of Energy

washington, DC 20545

\section{A. D. Barker \\ Battelle, columbus \\ Laboratories \\ $505 \mathrm{King}$ Avenue \\ Columbus, OH 43201}

J. R. Barker

Office of Environinental

Audit and Compliance

Departinent of Energy

Washington, DC 20545

N. F. Barr

ER-73, GTN

Department of Energy

Washington, DC 20545

S. Barr

Environinental Studies

Group

MS - D466

Los Alamos National Laboratory

P.0. Box 1563

Los Alamos, NM 87544

J. K. Basson

Raad Op Atoric

At oonkrag Energy Board

Privatsk $\times 256$

Pretoria 0001

REPURLIC OF SOUTH AFRICA

A. M. Beau, Librarian

Comnissariat à l'Energie Atomique

Département de Protection

Sanitaira

BP Nn. 6

$F-92260$ Fontenay-aux-Roses

FRANCF.

G. Bengtsson

Director-General

Statens Stralskyddsinstitut

Box 60204

5-104 01 Stockholm

SWFDEN
No. of

Copies

D. J. Beninson

Gerencia de Proteccion

Radiologica y Seguridad

Comision Macional de

Energia Atomica

Avenida del Libertador 8250

1429 Buenos Aires

ARGENTINA

A. Bianco

C.N.E.N.

Laboratorio Fisica

Sanitaria

V. Mazzini 2

40138 Bologna

ITALY

1. A. Bibb

DOE - Oak Ridge Operations

Office

P.0. Box E

Dak Ridge, TN 38730

J. F. Boatman

NOAA / ERL / AQC

325 Broadway

Boulder, Co 80303

L. C. Brazley, Jr.

NE-22, GTN

Departinent of Energy

washington, OC 20545

A. Brink

SASOL-One Limited

P.0. Box 1

Sasolburg 9570

REPUBLIC OF SOUTH AFRICA

J. C. Browne

Envi ronmental Studies

Group

MS-4114

Los Alamos National

Laboratory

P.0. Box 1663

Lo5 Alamos, NM 37545

P. Bun 1

FE-34, GTN

Department of Energy

washington, DC 20545 
No. of

Copies

R. J. Bull, Ph.0.

Associate Professor of

Pharmacology/Toxi cology

College of Pharmacy

Pullman, WA 99164-6510

D. Bunch

Assistant Secretary for Safety, Health and

Quality Assurance

EH-30, GTN

Washingtan, DC 20545

G. Burley

Office of Radiation

Pragrams (ANR-458)

U.S. Environmental

Protection Agency

Washington, DC 20460

W. W. Burr

Oak Ridge Associated Universities

P.0. Box E

Dak Ridge, TN 37830

N. Busch

Ris $\$$ National Laboratory

DK-40000 Roskilde

DENMARK

L. K. Bustad

Collee of Veterinary Medicine

Washington State University

Pullman, WA 99163

Cao Shu-yuan, Deputy Head

Laboratory of Radiation Medicine

North China Institute of Radiation Protection

Taj-yuan, Shan-xi

THE PEOPLE'S REPUBLIC OF CHINA

M. Carpentier

Comnission of the E.C.

200 Rue de la Loi

J-70 $6 / 16$

1049 8russels

BELGIUM

R. Catlin

Electric Power Research

Inst $\uparrow$ tiste

3412 Hillview Avenue

Palo Alto, CA 94304
No. of

Copies

CEC

DG XII Library

SDM8 R 1

200 Rue de la Loi

3-1049, Brussels

BELGIIJM

Chen Xing-an, M.D.

Laboratory of Industrial Hygiene

Ministry of Public Health

2 Xirkang Street

Deshangmanwai, Beijing

THE PEOPLE'S REPURLIC

I)F CHINA

G. H. Clark

Australian Atomic Energy Comission

Private Mail Bag

Sutherland NSW 2232

AUSTRALIA

J. A. Coleman

NE - 24, GTN

Departinent of Energy

Washington, DC 20545

Council on Environinental Quality

72 Jackson Place, NW

Washington, IOC 20006

J. B. Cunning

NOAA/ERL

325 Broadway

Boulder, CO 80303

P. H. Daum

Brookhaven National

Laboratory

Ipton, Lang Island, NY 11973

H. T. Daw, Director

International Atonic Energy Agency

Kaerntner ring 11

AlDio Vienna 1

AUSTRIA

C. P. Delisi

Department of Energy

ER-70, GTN

Washington, DC 20545
No. of

Copies

Deng Zhicheng

North Chind Institute of Radiation Protection

Tai-yuan, Shan-xi

THE PEOPLE'S REPUBLIC OF CHINA

G. DePlanque

13 Sowdoin Street

Maplewood, NJ D7040

M. H. Dickerson

L-262

P.0. Box 808

Livermare, CA 94550

P. R. Dickerson

Department of Meteorology University of Maryland

Coliege Park, MD 20742

Director

Commissariat à l'Energie Atamique

Centre d'Etudes Nucléaires

Fontenay-aux-Roses (Seine)

FRANCE

Director

Commonwealth Scientific and Industrial Research Organization

Aspendal, Victoria

AUSTRALIA

Qirector

Laboratorio di Radiobiologia Animale

Centro di Studi Nucleari Della Casaccia

Comitate Nazionale per 1 'Energia Nucleare

Casella Postale 2400

00100 Roma

ITALY

D. Djuric

Institute of Occupational and Radiological Health

11000 Beograd

Deligradoka 23

YUGOSLAVIA

H. Drucker

Arganne National

Laboratory

9700 South Cass Avenue

Argonne, IL 60439 
No. of

Copies

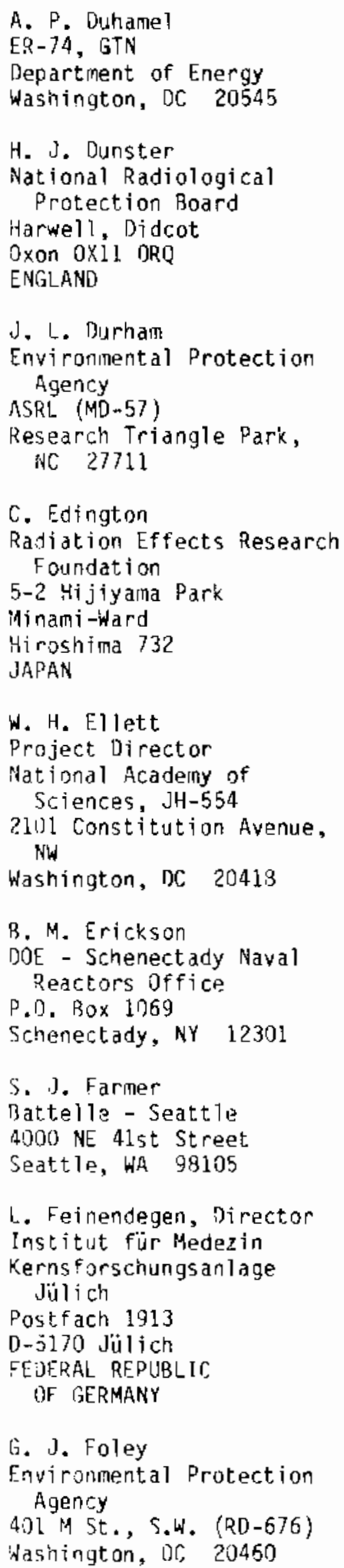

No. of

R. M. Fry, Supervising Scientist

Office of the Supervising Scientist for the Alligator Rivers Region

P. D. Box 387

Bondi Junction NSW 2022 AUSTRALIA

G. B. Gerber

Radiobiology Department

Commission of European Communities

Rue de la Loi

Brussels

BELGIUY

A. R. Gopal-Ayengar

73-Mysore Colony

Mahul Road, Chembur

Bombay-400 074

INDIA

G. H. Gronhovd

Grand Forks Enerqy Research Center

Department of Energy

Box 8213, University Station

Grand Forks, ND 58202

d. W. Healy

51 Grand Canyon Drive

White Rock, NM 87544

B. Hicks

National Oceanic and Atmospheric Administration

At nospheric Turbulence and Diffusion Laboratory

P.O. Box E

Oak Ridge, TN 37830

F. Hutchinson

Department of Molecular Biophysics and Biochemistry

Yale University

P.0. Box 6666, 260 Whitney Ave.

New Haven, CT 06511

D. Irwin

Librarian

Supervising Scientist for the Alligator Rivers Region

P. . B. 30x 387

Bondi Junction 2022

AUSTRAL IA
No. of

Copies

H. Ishikawa

General Manager

Nuclear Safety Research Association

P.0. Box 1307

Falls Church, VA 22041

K. E. Lennart Johansson

National Defense Research Institute

FOA 451

S-901-82, bmea

SWEDEN

A. Johnson

Vice President for

Academic Affairs

San Diego State University

San Diego, CA 92128

L. J. Johnson

EG\&G Idaho

P. 0, Box 1625

Idaho Falls, ID 83415

G. Y. Jordy, Director ER-30, GTN

Department of Energy

Washington, DC 20545

V. A. Kamath

Scientific Information officer

Library \& Information Service

Atomic Energy

Establishment, Trombay

Apollo Pier Road

Bombay -1

INDIA

Dr. rer. nat. Hans-Joachion Klimisch

BASF Aktiengesellschaft Abteilung Toxikologie

D-6700 Ludwigshafen FEDERAL REPUBLIC OF GERMANY

F. Koomonoff ER-12, GTN Departinent of Energy Nashington, DC 20545

R. Kornasiewicz Mail Stop 1130-55, ONRR Nuclear Regulatory Comission

Washington, DC 20555 
No. of

Copies

\section{R. T. Kratzke EH-131, GTN Department of Energy Washington, DC 20545 \\ L. Kristensen \\ Physics and Meteorology Ris National Laboratory DK-4000 Roskilde DENMARK}

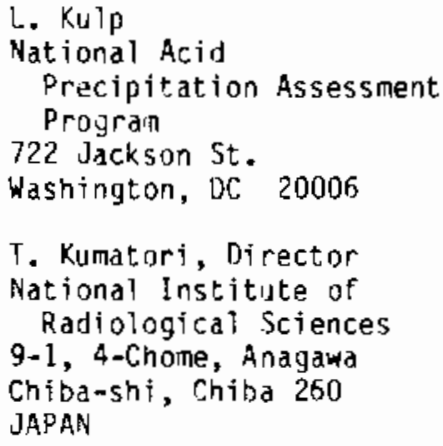

No. of

Copies

$$
\begin{aligned}
& \text { Li De-ping } \\
& \text { Professor and Director } \\
& \text { of North China Institute } \\
& \text { of Radiation Protection, } \\
& \text { NMI } \\
& \text { Tai-yuan, Shan-xi } \\
& \text { THE PEOPLE'S REPUBLIC } \\
& \text { OF CHINA }
\end{aligned}
$$

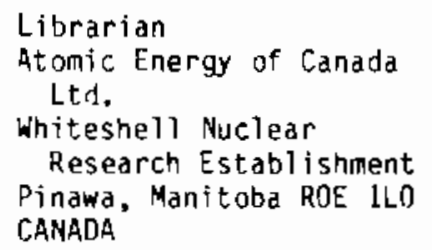

Librarian

Atomic Energy Research Establishment

Building 465

Harwe 11, Didcot

Oxon OX11 ORO

ENGLAND
Librarian
Australian Atomic Energy Commission
Riverina Laboratory
P.O. Box 226
Deniliquin, New South
Wales 2710
AUSTRALIA
Librarian
Brookhaven Nationa 1 Laboratory
Research Library, Reference
Upton, Long Island, NY 11973
Librarian
Centre d'Etudes
Nucléaires de Saclay
P.0. Box 2, Saclay
$\mathrm{Fig-sur-Yvette} \mathrm{(S \& O)}$
FRANCE
Librarian
Colorado State Iniversity
Serials Section
Ft. Collins, ro 80521

No. of

Copies

\author{
Librarian \\ Commonwealth Scientific \\ and Industrial Research \\ Organization \\ 314 A1bert Street \\ P.0. Box 89 \\ East Melbourne, Victoria \\ AUSTRAL IA
Librarian
Commonwealth Scientific and Industrial Research Organization
Private Mail Bag, P.O.,
Deniliquin, New South
Wales 2710 \\ Rangelands Research Centre \\ AUSTRALIA \\ Librarian \\ ENEA (OECD) Health and \\ Safety office \\ 38, Blvd. Suchet \\ Paris \\ FRANCE \\ Librarian \\ HCS/EHE \\ World Health Organization \\ $\mathrm{CH}-1211$ Geneva 27 \\ SWITZERLAND \\ Librarian \\ Health Sciences Library, \\ SB -55 \\ University of Washington \\ Seattle, WA 98195 \\ Librarian \\ Kernforschungzentrum \\ Karlsruhe \\ Institut für \\ Strahlenbiologie \\ $0-75 \mathrm{Karls}$ ruhe 1 \\ Postfach 3640 \\ FEOERAL REPUBLIC \\ OF GERMANY \\ Librarian \\ Lawrence Livermore \\ National Laboratory \\ University of California \\ Technical Information \\ Dept., L-3 \\ P.O. Box 808 \\ Livermore, CA 94550
}


No. of

Copies

Librarian

Los Alamos National

Laboratory

P.0. Box 1663

Los Alamos, NH 87545

Librarian

Max-Planck-Institut fur Biophysics

Forstkasstrasse

D-6000 Frankfurt/Main

FEDERAL REPUBLIC

OF GERMANY

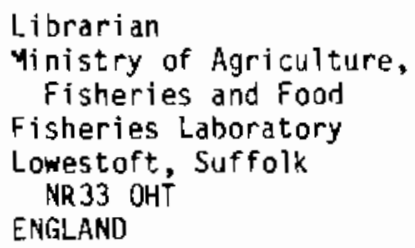

Library

Ris National Laboratory DK-4000 Roskilde

DENMARK

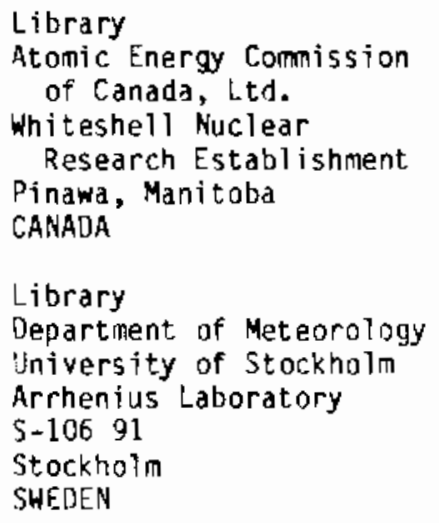

No. of

J. N. Maddox

ER-73, GTN

Department of Energy

Washington, DC 20545

W. J. Madia, Director

Battelle Columbus

Laboratory

$505 \mathrm{King}$ Avenue

Coluntus, $O H \quad 43201$

J. R. Maher

ER-65, GTN

Department of Energy

Washington, DC 20545

B. Manowitz

Energy and Environment Division

Brookhaven National Laboratory

Upton, Long Is land, NY 11973

A. M. Marko, Director Atomic Energy Comission of Canada, Ltd.

Biology and Health Physics Division

Chaik River Nuclear Laboratories

P.0. Box 62

Chalk River, Ontario KOJ IJO

CANADA

Q. D. Mayhew
ER-63, GTN
Department of Energy
Washington, DC 20545
H. M. MCCammon
ER-75, GTN
Department of Energy
Washington, DC 20545
R. O. McClel1an
Inhalation Toxicology
Research Institute
Lovelace Foundation for
Medical Education and
Research
P.0. Box 5890
A1buquerque, NM 87115
T. F. McCraw
EH-132, GTN
Department of Energy
Washington, DC 20545

No. of

Copies

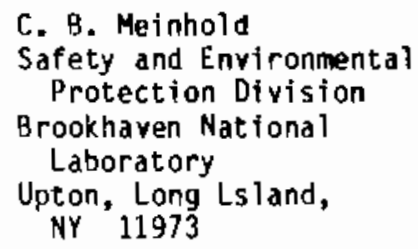

M. L. Mendelsohn

Environmental Research Program

Lawrence Livermore National Laboratory, L-523

University of California

P.0. Box 808

Livermore, CA 94550

P. Michael

Brookhaven National

Laboratory

Upton, NY 11973

M. L. Minthorn, Jr. ER-72, GTN

Department of Energy

Washington, DC 20545

D. R. Mont $i$

ER-14, GTN

Department of Energy

Washington, OC 20545

B. Morgan

Environmental Division

DOE - Savannah River Operations office

P.0. Box A

Aiken, SC 29801

H. Mases

ER-74, GTN

Department of Energy

Washington, DC 20545

W. E. Mott

EH-12, GTN

Department of Energy

Washington, DC 20545

P. Mueller

EPRI, Environmental

Science Department

P.0. Box 10412

Palo Alto, CA 94303 
No. of

Copies

R. Nathan

Battelle Project

Management Division

$505 \mathrm{King}$ Avenue

Columbus, $\mathrm{OH} 43201$

S. M. Nealey

Battelle - Seattle

4000 NE 41st street

Seattle, WA 98105

W. Neff

Wave Propogation Lab, NOAA

325 Broadway

Boulder, CO 80303

N. Nelson

Environmental Protection Agency

Washington, DC 20460

J. C. Nénot, Deputy Di rector

Dêpartement de Protection

Centre d' Etudes

Nucléaires

BP No. 5

F-92260 Fontenay-aux-Roses

FRANCE

L. Newman

Brookhaven National Laboratory

Upton, Long Island. NY 11973

W. R. Ney, Executive Direct or

National Council on Radiation Protection and Measurements

7910 Woodmont Averue

Suite 1016

Bethesda, MD 20814

Nuclear Regulatory

Commission

Advisory Comittee on Reactor Safeguards

Washington, OC 20555

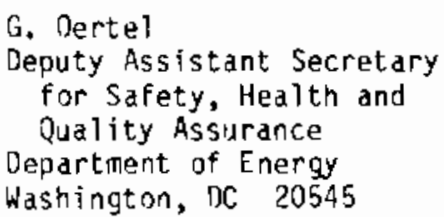

No. of

Copies

D. E. Olesen

Battelle Memorial

Institute

505 King Avenue

Columbus, $\mathrm{OH} 53201$

J. P. Oliver

ENEA (OECD) Health and Safety office

38, Blyd. Suchet

Paris

FRANCE

B. Ottar

Director

Norwegian Institute for

Air Research

Eivegaten 52

$\mathrm{N}-2000$ Lillestrom

NORWAY

N. Parmentier

Départment de Protection Centre d'Etudes Nucléaires BP No, 6

F-92260 Fontenay-aux-Roses

FRANCE

A. A. Patrinos
ER-74, GTN
Departinent of Energy
Washington, DC 20545
R. S. Paul
Battelle, Columbus
Laboratories
505 King Avenue
Columbus, OH 43201
A. A. Pitrolo
Morgantown Energy Research
Center
Departinent of Energy
P.O. Box 880
Margantown, wV 26505
L. Prahm
National Agency
of Environmental
Protection
Ris Natianal Laboratory
DK-4000 Roskilde
DENMARK
V. Prodi
Departinent of Physics
University of Bologna
Via Irnerio 46
I-40126 Bologna
ITALY

No. of

Copies

\author{
R. G. Rader \\ ER-33, GTN \\ Department of Energy \\ Washington, DC 20545 \\ D. P. Rall, Director \\ NIEHS \\ P.0. Box 12233 \\ Research Triangle Park, \\ NC 27709 \\ C. R, Richmond \\ Oak Ridge National \\ Labaratory \\ P.0. Box $X$ \\ Oak Ridge, TN 37830
}

J. S. Robertsan

ER-73, GTN

Department of Energy

Washingt on, DC 20545

H. Rodhe

Meteoralogical Institute

Stockholm University

S-10691 Stockholm

SWEDEN

P. J. A. Rambout

Inhalation Toxicology Department

National Institute of Public Health and

Environmental Hygiene

P.0. Box 1, 3720 BA

Biithoven

THE NETHERLANDS

M. Roy

Institut de Protection et de Sureté Nucleaire

Départment de Protection Sanitaire

Service d'Etudes Apliquées de Protection Sanitaire

BP No. 6

$F-92260$ Font enay-aux-Roses FRANCE

J. M. Rusin

404 W. Kalladay

Seattle, WA 98119

M. Rzekiecki

Comissariat à l'Energie Atomique

Centre d'Etudes

Nucleaires de Cadarache

BP No. 13-St. Pau 1

Les Durance

FRANCE 
No. of

Copies

$$
\begin{aligned}
& \text { L. Sagan } \\
& \text { Electric Power Research } \\
& \text { Institute } \\
& 3412 \text { Hillview Avenue } \\
& \text { P.O. Box } 10412 \\
& \text { Palo Alto, CA } 94304 \\
& \text { R. A. Scarano } \\
& \text { Nuclear Regulatory } \\
& \text { Commission } \\
& \text { Nill Licensing Section } \\
& \text { Washington, OC } 20545 \\
& \text { F. A. Schiermeier } \\
& \text { Envi ronmentai Protection } \\
& \text { Agency } \\
& \text { Envi ronmental Sciences } \\
& \text { Research Laboratory } \\
& \text { (Mo-57) } \\
& \text { Research Triangle Park, } \\
& \text { NC } 2771
\end{aligned}
$$

M. Schulman

ER-70, GTN

Jepartinent of Energy

Wasinington, oc 20545

R. Setlow

Brookhaven National

Laboratory

Upton, NY 11973

R. Shikidr

Battelle - Seattle

4000 NE 415t Street.

Seat.tle, WA 98105

i. Silini

Secrelary, IJNSCFAR

Vienna Internationa

Center

P.0. $30 \times 500$

A-1400 Vienna

AUSTRIA

3. Simmons

Bioeffects Analysis Branch

U. S. Envi roninental Drotection Agency

401 M Street S.W.

Washington, DC 20460

W. K. Sinclair, President. National rouncil on

Radiation Protection

and Measurements

7910 Woodinant Avenue

Suite 1016

3ethesida, MO 20814
No. of

Copies

R. Skogstrom, Chief Librarian

Meteorological Institute

University of Stockholra

Arrhenius Laboratory

\$106 91 Stockholm

SWEOFEN

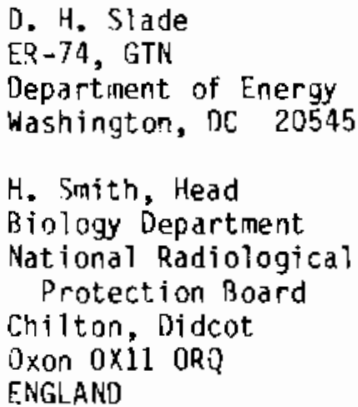

G. A. Smithwick

Deputy Assistant Secretary for Environment

EH-20, FORS

washington, DC 20585

J. Snow

ER-6, FORS

Departiment of Energy

Washington, DC 20585

J. H. Spickard, M.D.

EG\&G Idaho, Inc.

P.0. Box 1625

Idaho Falis, II 33415

1) N. Stannard

17441 Plaza Animado \#132

San Diego, CA 921?8

R. J. Stern

EH-10, FORS

Department of Energy

washington, DC 20585

J. F. Stevens

Dayton Area Office

DOE - Albuquerque

Operations office

P.i). $30 \times 66$

Miamisburg, OH 45342

F. T. Still

Kerr-McGee Corporation

P.D. Box 25851

Ok lahoma City, OK 73125
No. of

Copies

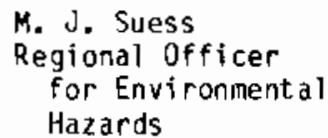

World Health Organization

8, Scherfigsvej

DK-2100 Copenhagen

DENMARK

Sun Shi-quan, Head

Radi ati on-Hedicine Department

North China Institute of Radiation Protection

Tai-yuan, Shan-xi

THE PEOPLE'S REPUBLIC OF CHINA

F. Swanberg

Nuclear Regulatory

Commission

Washington, DC 20545

J. Swinebroad

EH-12, GTN

Department of Energy

Washington, DC 20545

Technical Information

Service

Savannah River Laboratory

Room $773 \mathrm{~A}$

E. l. du Pont de Nemours \& Company

Ajken, SC 29801

J. N. Thiessen

ER-71, GTN

Departinent of Energy

Wasinington, DC 20545

R. G. Thomas

$E R=72$, GTN

Department of Energy

Washington, IC 20545

M. Thorne

International Commission on Radiological

Protection

Clifton Avenue

Sutton, Surrey

ENGLAND

C. Tiller

$R G-30$, FORS

Departinent of Energy

washington, DC 20585 
No. of

Copies

A. W. Trivelpiece, Director

$E R-1$, FORS

Departinent of Energy

Washington, DC 20585

United Nations Scientific Committee on the Effects of Atomic Radiation

Vienna International Center

P.D. Box 500

A-1400 Vienna

AUSTRIA

U.S. Department of Energy

Environment, Safety and Health Division

P. O. Box 5400

A)buquerque, NM 87115

E. J. Valtario

EH-13, GTN

Departinent of Energy

Wasinington, of 20545

D. Van As

Private Bag $\times 256$

Pretoria 0001

Atomic Eneray Board

REPUBLIC, OF SOUTH AFRICA

C. R, Vest

Batteile Memorial

Institute

Washington Operations

2030 in Street, NW

Washington, DC 20036

Vienna International

Centre Library

Gifts and Exchange

P.D. Box 190

$A \rightarrow 1400$ Vienna

AUSTRIA

G. .]. Vodapivc

DOE - Schenectady Nayal

Reactors office

P. ก. Sox 1069

Schenectady, NY 12301

F. L. Voelz

Los Alamos National

Laboratory

P.0. Box 1563

Los Alamos, NM 87545
No. of

Copies

H. L. Volchok

Environmental Measurements Laboratory

Department of Energy

375 Hudson Street

New York, NY 10014

B. W. Wachholz

Low Level Radiation Effects 3 ranch

National Cancer Institute

Landow Bidg., Room BC09

Rockville Pike

Bethesda, MD 20205

M. L. Walker

$E H-1$, FORS

Departinent of Energy

Washington, DC 20585

M. F. Walsh

Battelle - Seattle

$4000 \mathrm{NE}$ 41st Street

Seattie, WA 98105

Wang Hengde

North China Institute of

Radiation Protection

P.0. Box 120

Taj-yuan, Shan-xi

THE PEOPLE'S REPUBLIC OF CHINA

Wang Renzhi

Institute of Radiation

Medicine

11\# Taj Ping Road

Beijing

THE PEOPLE'S REPUBLIC,

OF CHINA

Wang Ruifa, Associate Director

Laboratory of Industrial Hygiene

Ministry of Public Health

2 Xinkang Street

Deshangmanwai, Peijing

THE PEOPLE'S REPURL IC OF CHINA

ivang Yibing

North China Institute of Radiation Protection

P.). Box 1 ?0

Tai-yuan, Shan-xi

THE PEOPLE'S REPURLIC OF CHINA
No. of

Copies

R. A. Walters

Los Alamos National

Laboratory

Assistant to the Associate Director

P.0. Box 1663

$45-A 114$

Los Aiamos, NM 87545

R. L. Watters

ER-75, GTN

Department of Energy

Washington, OC 20545

Wei Luxin

Laboratory of Industrial Hygiene

Ministry of Public Health

2 Xinkang Street

Deshangmanwai, Beijing

THE PEOPLE'S REPUBLIC DF CHINA

C. G. Welty, Jr.

EH-123, GTN

Departinent of Energy

Washington, $\propto 20545$

I. Wender

Dept. of Chemica?

Engineering

1249 Benedum $\mathrm{Ha} 1 \mathrm{l}$

University of Pittsburgh

Pittsburgh, PA 15261

M. L. Wesely

Argonne National

Laboratory

Buflding 181, ER

Argonne, IL 60439

W. W. Weyzen

Electric Power Research Institute

$3412 \mathrm{Hillyiew} \mathrm{Ayenue}$

Palo Alto, CA 92665

H. M. Williamson DOE - Idaho Operations Commission

550 Second Street

Idaho Falls, ID 83401

B. C. Winkler, Director Licensing

Raad op Atoomkrag/Atomic Energy Board

Privaatsk $X 256$

Pretoria 0001

REPUBLIC OF SOUTH AFRICA 
No. of

Copies

$$
\begin{aligned}
& F . \text { J. Wobber } \\
& 14 \text { Goshen Court } \\
& \text { Gaithersburg, } \\
& \text { (1) } 20879-4403
\end{aligned}
$$

M. T. Wood

Battelle - Seattle

$4000 \mathrm{NE} 41 \mathrm{st}$ Street

Seattle, WA 98105

R. U. Wood

ER-74, GTN

Department of Energy

Washington, DC 20545

Wu De-Chang

Institute of Radiation

Medicine

11\# Tai Ping Road

Beijing

T'HE PEOPLE'S REPUBLIC OF CHINA

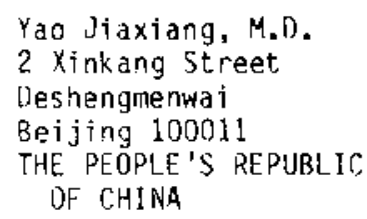

Zhixian Zhu

North China Institute of Radiation Protection

P.0. Box 120

Taj-yuan, Shan-xi

THE PEOPLE'S REPUBLIC,

$$
\text { OF CHINA }
$$

\section{ONSITE}

5 DOE Richland Operations Office

P. K. Clark

D. R. Elle

E. Go1dberg

R. Rochette

J. J. Sutey
No. of

Copies

2 Joint Center for Graduate Study

J. Finnigan

B. Vallet

2 Hanford Environmental Health

B. D. Breitenstein

R. D. Gilmore

134 Pacific Northwest Laboratory

0 . B. Abbey

K. J. Allwine

R. W. Baalman

J. F. Bagley

W. J. Bair (15)

4. R. Barchet

K. H. Busness

D. B. Cearlock

T. Q. Chikalla

D. S. Daly

M. T. Dana

J. M. Davidson

W. F. Davis

G. W. Dennis

D. W. Dragnich

R. C. Easter

C. E. Elderkin (20)

R. M. Fleischman

J. J. Fuquay

W. A. Glass

D. W. [alover

R. H. Gray

R. K. Hadlock

J. M. Hales (5)

R. V. Hannigan

L. C. Harrison

P. C. Hays

D. J. Hoitink

T. W. Horst

B. J. Kelman

N. S. Laulainen (5)

f. 1.. Laws
No. of

Copies

R. N. Lee

A. C. Leslie

C. G. Lindsey

F. D. Lloyd

D. G. Luecken

J. A. Mahaffey

R. P. Marshall

L. N. McKenney

A. H. Miller

J. M. Nielsen

E. L. Owczarski

J. F. Park

W. T. Pennell (5)

R. W. Perkins

A. M. Platt

D. C. Powell

D. S. Renne

W. D. Richmond

G. F. Schiefelbein

L. C. Schmid

G. A. Sehmel

D. S. Sharp

W. G. N. Siinn (10)

R. A. Stokes

J. A. Stottlenyre

D. L. Strenge

J. M. Thorp

L. H. Toburen

B. F. Vaughan

L. L. Wendel1 (5)

R. E. Wildung

W. R. Wiley

L. D. Williams

R. K. Woodruff

T. A. Zinn

Life Sciences Library (2)

Publishing Coordination (2)

Technical Report Files (5) 


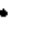

